University of Louisville

ThinkIR: The University of Louisville's Institutional Repository

Electronic Theses and Dissertations

1935

\title{
The Saar problem.
}

Georgia Wheeler

University of Louisville

Follow this and additional works at: https://ir.library.louisville.edu/etd

Part of the Diplomatic History Commons, and the European History Commons

\section{Recommended Citation}

Wheeler, Georgia, "The Saar problem." (1935). Electronic Theses and Dissertations. Paper 1942.

https://doi.org/10.18297/etd/1942

This Master's Thesis is brought to you for free and open access by ThinkIR: The University of Louisville's Institutional Repository. It has been accepted for inclusion in Electronic Theses and Dissertations by an authorized administrator of ThinkIR: The University of Louisville's Institutional Repository. This title appears here courtesy of the author, who has retained all other copyrights. For more information, please contact thinkir@louisville.edu. 


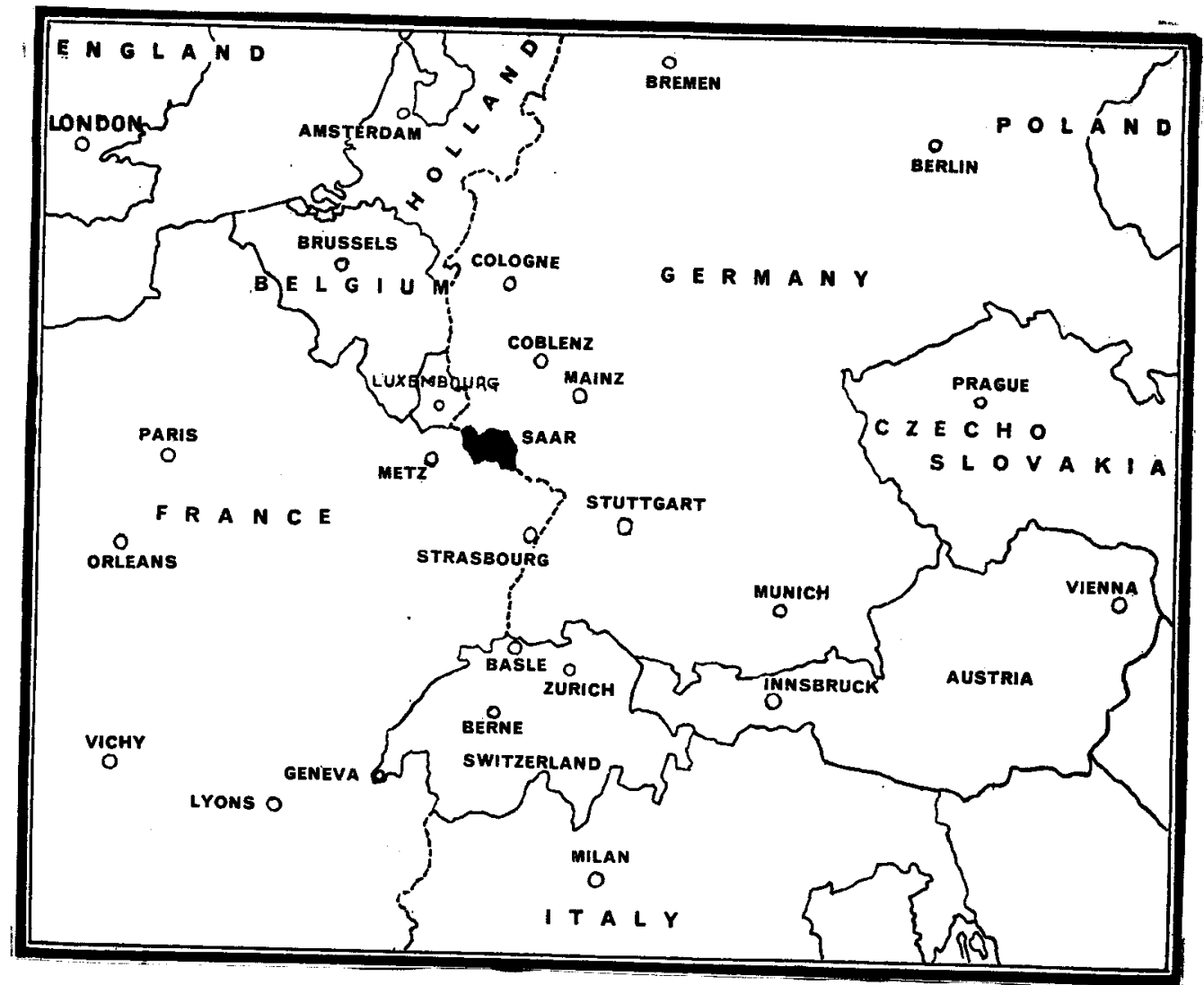


THE SAAR PROBLEY

\author{
A Diseertation \\ subsitted to the raoulty \\ of the Oraduate sohool of the Univereity of Louleville \\ In Partial Fulsilinont of the \\ Requiremonte for the Degree \\ Or laster of arte
}

Departmant of History

by

Gorgla Wooler

Toar

1938 


\section{ACKNOWLEDOUENT}

The holptul asoletanee and raluable ouggestlons of Dr. W. C. Hallalleu, who dirocted this investigation, workt an expresesion of deepest gratitude. To bave studied under the guldanoe of so thorough - wholar, who poseesees and maintalns the high 1deal of acouracy and Intelleotual achlevement, bas been a rare pririlege. 
TABLE OF CONTANTS

The Territory of the $\operatorname{san}($ map)............ Frontieplece

Introduction. .......................... Page 1

Chapter

I. The Peace Conforence...................

II. The Treaty Protisions.................. 27

III. Boonomis Dorelopment................. 36

IV. The 0ooupation.....................6 61

v. The Political situation................ 91

vI. Labor and Soolal Rolationt................204

vII. The Plebleodte........................217

Conozuston.................................233

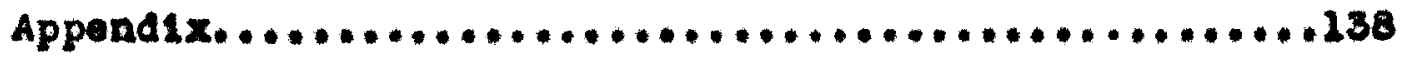

B1bllography.................................259 
INT RODUCTION 


\section{INTRODUCTIOA}

The saar Torritory is an intoresting politioal oddity oreatod Irom a Peace Conference Compromise. The saar problem, as it ex1ste since the war and prior to the pleblect to cannot be diroreed from the ovonts provious to 1t. The problea has its origin in the ooonomic, oultural and political development of the area. The saar is also ourtous, it not unlque, Industrial center. The sear's elgnificanee in international politics is derived from ite posseseston of raluable mineral resources and its locetion. This region is possessed of a highly doveloped and world renowned Industry. Because of Ito economio position and derelope want, it was highiy ooreted by two stetes, Franee and Germany.

Today, we find in the sear Torritory a population that is Cerman in al2 respects. No one can doubt the bermanle nature of these people. Language, race, oulture, tradition, all combine to make thos, in the riosestivdes of history, cundamentally falthful to tho Cerman 1deal. Thle sact gives to its oonsideration a partloular acutonese.

A close exanination of the sear problen abould be made by all those interested in vorld affalre. The destiny of the Sear 1. a quostion of Ittal importanoe. Intermational relationshlpo and possibly oren the poace of surope are closely bound with Ite solution. International evente may again doal with this territory in a manner similar to 2919.

The gorernment of the Saar Basin by a Commission of the 
League of Nations is a very interesting experiment in international administration. It also affords a most interesting example of how the principles of self-deteraination were applied at the Peace Conference. The Saar jesin is tho ono and only instance in which the League of liatious has boen entrusted w th a mardate to govern, and 16 is explicitly provided that it Is to govern as trustoe. The Loague has accordingly accepted the obligation to govern a poople and tho territory in which they live, In accordance with the highest principles of truth, justice, and impartiality. The manner in which the League is performing this task is of the greatest interest to the whole world.

It 18 with the problem as brought to a crux in the treaty. the agreement, and under the plebiscite that this study will particularly deal. The fact that we are still so cluse to the - vents makes a falr judgment of the case a most difflcult one. This difficulty is not diminishod by tho wature of the material aval2able, which 18 of a propagandist nature on either sicie. No other part of Europe suggests more vividiy the intricate complexities of past and present political and national conll1cts than does the area along the Franco-cirman frontier. This secular etrubsio has gone on in timo of peace as well as In time of war. Its latest phase was the contest for the control of the Saer Territory which found its soltuion in the pleb1sc1te of January 13, 1935. To understand the saar problem $1 t$ 18 necessary to take a physical and social survey of the terr1- 
tory whioh shall take account of 1 ts location, its coonomic character, the temper and affindties of 1 ts population and their oconomic a well as tholr political and cultural relations with the rest of the world. 


$$
\text { C H A P T E R I }
$$

THE PEACE CONFERENCE 


\section{CHAPTIER I}

THE PEACE CONFERENCE

The Saar, as 1t existed prior to the plebisolte was a wolIy artiflclal oreation. The region which under French pressure was relinquiahed by Germany and designated as the Saar distriot. was nelther a geograph10 nor an economie untty. On the contrary. the nowly creatod Saar distriet was artiflolally soparatod by political boundaries from 1 ts neighboring and economically oonnected regions. 1 For the nost part the saar region wes arbitrarily out out from Prussian territory. to a lesser extent from the Bavarian Palatinato and 1 to boundarios were so drawn as to 8170 1t, as far as possible, an eoononic unity. $z$ Thus not only the Saar valley in large part but also a region extending north beyond st. Nendel and east to the town of Howburg was lncluded. 3 The tracing of the saur erontiers was largely determined by the location of the coal mines, to whioh were attached the country Inhabited by the miners and by the worker employed in the 1 ron, oteel and other Industries. 4 on the wost and south the saer is bounded by Lorraine, to the north it faces Thentsh Prussia, from

${ }^{1}$ Bruning. R. "Die Natur11chers Landsohaster Des Saargeb1etes," Seglal Solenoe Abetract. Vol.II, (1929), p. 3564.

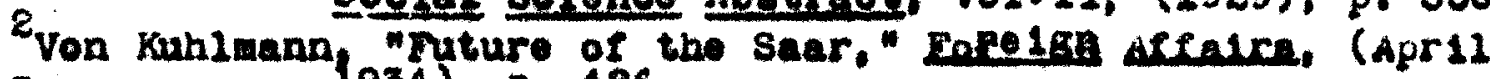
3 Rus se 1 Frank 1934 , The Interpatsonel Gorernment of the saer. 4kioerakorn, Fritz, "Firteen Hundred Xears of Sacr History," Chicaso Tribune, "Saar supulement," No. $E_{\text {, (June }}$ 13, $1 9 3 4 \longdiv { , p . 1 0 . }$ 
whtoh 1 t was for the most part carred, and to the oast lay the Bavarian Palatinate, a sall portion of which was included in 1t. It roughly elliptioal area ineluded 738 square miles. The saar River, rieing in Lorraino, Slowing northwesterly close to the Frenoh erontier, and enptying lato the Hoedle to the north, glves the region the nams and oblet geographlo charaeter. 6 One of the wain naturel pathways between France and Germany, 14 has been tramped aorose by laveding armies of both Franoe and Cermany. 7 Today two of the ohter continental raliway ines pese through 1t. It largest olty. Saarbruoken, is an important contor in the notwork of surope's automab1le roads and air routes. It is regarded, therefore, as area of immonse otrategie valuo, for offenese or defenee, to both dermany and Franes. 8 The contral forest and Industrial territory conesets of the ooal mountain territory, the variegated candetone belt, and the industrial sone in the saar valley. Tnese reglons are aurrounded by the open agrloultural territorlos. Al2 the different reglons of the sear are bound to Carmany by the national and oudtural unity of the Oorman spirit,"

The saar question had no signifloant existenoe prior to the Paris Peace Conferenee, It was the Treaty of Versalzes thet oreatod a saar question and gave to lt 1 to peculiar and unusual charactec France, acoording to Frenoh authority, we coonomically EVon KunLmann, Loe. 91t., p. 486. Bardous, Jegques, "rho Torritory of the saar," Chleare Tribune, "sear Supplement," No. 1, (Xay 13, ${ }^{7}$ Kloorekorn, $\operatorname{Trit2},{ }_{100}$, elte, p. 12. Iblde. p. 10. Eruning, R., gR. Q1t.. p. 3564. 
juetifled in olalaing the entire sagr coal bastn because of tho destruotion suffered by the coal mines in the north of France, and surther aho had a moral and historlo claim of right to a large part of the territory because it is inbabited by a people who are Fronoh in race, traditions, and aspirations, 20

Thls argument was relnforeed by historloal considerations. The Saar Baeln of 738 square m1les, contalning one of the rlohest deposits of coal in all surope, was long contended for by Franoe and cermeny. 11 Tw1oe it was under French oontrol, onoe under Loule XIV (1668 to 1697) and another seotion during the Fronoh Revolution in 2798, and later under Napoleon (2798 to 1815). 12 The fortifiontions of saarlouid, now the sixth largest olty in the territory, were bust by Vauban, the French KIng'b great m111tary engineer. 13 In 1697 the whole of the Sanr Territory. with the exception of Banrlouls, was 2ost by Franoe. 14 The latter of ty remalned under French rule unt11 1815.16 It was not unts the French Revolution (1792), however, that the ent1re region of the sear we aded to France. 16 For Napoleon's wide conqueste the saar furntabed many soldiere and officers among thew the famous Harahal Noy. In 1824 by the Treaty of Paris, France 20 t all but the o1t1es of Saarbrucken and Saarlouls,

11 Taralou, Andre. The Truth About the Ireaty, (1921), p.250.

12Ibid." p. 852. "The Sear In French History," Dhicaso Trebun, "Suer Supplement," No. 1. (tay

$13.16,2934), p .10$. Habkine. Chas. "L. Lord, Hobert H. Some Frobleme of the 14 pold.. p. 138 . Panos Concerance, (1920), p. 135.

16 House; E. H. \& Seymour, Chas. What Really Happonod at 16. Perse. (1921), p. 53.

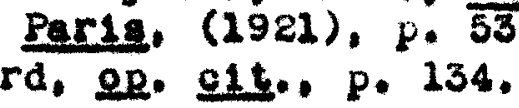


and certain territory on the right bank of the sear fiver. She was forced to givo up tnis in 2825 when the Saar basin wes incorporated in tho Statos of Pruesie and bevaria.17 The French had hopes of recovering the country after the restoration and extending their boundary that wuoh oloser to the Rhine until the derelopment of minos in the $2840^{\prime} \mathrm{s}$ brought in such a wave of corman workers as to make tho country overwhelmingly German in character. So the queation did not come up again until the close of the World War. It was maintalned by the Fremo delogation at Versailies that in spite of the relative brevity of the pertod during whioh the Territory had been under French rule, the region very largely preserved 1 t B Erench character and had distinot prowronoh aymothies. 18

A clain to tho saar formed no part of the publicly defined war alms of the French government, al though it was the aubject of a seoret agreoment between the Fronoh government and Czarist Ruende (1917) by whioh the former was to be given the Saar coal basin. ${ }^{29}$ studies made by rrench experts in preparation for the Peace Conference recommended that in taking back Alsace-Lorraine the coal supp $2 y$ necessary for the induetries of these provinoes should be aesured by also annexing the Saar. 80 M. Andre Tardieu Arew up a memorandum which demanded as alnimum the whole saar Bas 1n. 21

${ }^{27}$ Temper2ey, H.W.V., A Biatory of the Peace Conference of

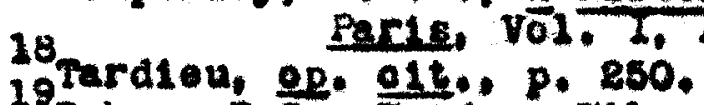

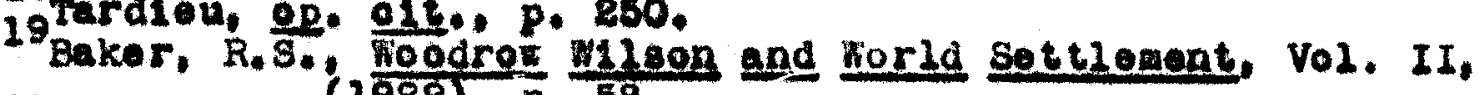
20 Tb1d., p. 18 , DOC. 2.38 . 22 Hold:. p. 18, Doc. 2 . 
When $1 t$ became clear that the whole of Aleace-Lorraine as annexed by Germany in 1871 would return to France, Industrial18t. familiar with the conditione of iron and ateel making in Alsace-Lorraine must have olearly porcelved that the vast steel Industry which dermen enterprise had bullt up there would be in - precarlous position without the saar coal deposits, on which 1t had depended alwost exclusively, 28

The Iron and steol Industry of the saar district has been developed as a result of the olose proxinlty of the Lorraine Iron ore and the Saar coal. There is an abundance of coal in the saar distriot but praoticaliy no iron oro. The coal, though extensively used, 18 not of the best coklag variaty. Woot of the ore is brought from Lorraine Annexfe, the rallroad haul being about so kilomoters. It has been estlmatad that the coal reserves of the saar total $26,500,000,000$ tons. 23

Before the par, France Imported annually 23,000,000 tons of coal. Nith the addod noade of fisace and Lorraino, she would therofore without the Sar coal be oblibed to 1miort oven after the re-ostabliahmont of her gines in the north, thirty milison tons, and, until thls re-establishment, sifty pilison out of a total conoumption of seventy-i1ve a12110n. In other words, France would be ocononlcally tributary to Germany, who, through coal, would control the prioes of all Frenoh ateol and Iron in the

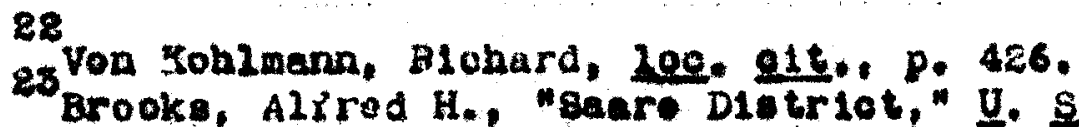
surrex, Bill. 703, (2980), $\vec{p}, 73$. 
-ast and thus doninate Fronch polieies. 84

German manufaoturers thomeelves had written in trodr momorandum to the Chancelior on way 20,2915 , "Coal 18 one of the most deolstre of polition faotors. The neutral oountries are dependent upon the belligerent who can aupply thom wh coal." "Consequentiy 11 Franoe were lert without coal Cermany's domination over her would be assured," stated Tardiou. 85

strategicaliy it was reoognized that the district possosed a real cefensive importanoe. The frontier at the north of Lorra ine muns dangerously alooe to the Thlonville and Briey lron1102ds, and make it poselble for sudden goup to paralyze the Frenoh Industrial syoter, as bappened at the beginning of the World War. 26 Tiny Saar's atratogioal position on the pakes 1t politicalig important. Lying aoross a natural pathway between Prance and Cermany, trade flowe aerose the Saar in times of poace jugt as armies maroh over it in war time. The Roman armies, those of Louid XIV, of Napoleon, and of the World War, al1 passed this way.

The French vacties revealed considerable consusion when they began to explain to the ailles why they belleved they had a right to annex tho saer. But both the mining area and the frontiers to be drawn up at the disoretion of tho Frenoh government, so as to provide for the strategleal neede

$$
\begin{aligned}
& \text { 84thrdien, op, alt, p. } 258 \\
& \text { 85 } 2 \text { bid.. p. } 259 \\
& \text { 87Temperlgy, H,W,V, OD, e14., Vol. II, P. } 177 . \\
& \text { simploit, Froderiok, "what Is The saar," The Nathonal } \\
& \text { gegraphle kagazine. (Feb, 1935), ToI, 6\%, P. } 244 .
\end{aligned}
$$


and for the inelusion in French territory of the entire iron distriot of Lorralne and of the entire coal distriot of the saar valley, had been inoluded in the secret agreenent with Fuesia in 1927.88 The Fronoh dosires, as formulated in a note of 11. Briand, had been made known to the British Oorernmont In the oourse of the same year. Briand stated that "It seens advisable to form an autonomous tete on the left hank of tho Fhine." Alecice and Lorralne muet, ho sald, be returned to Franoe not dinlnished as under the preaty of 2816 but with boundarion such as wore oonstituted in 1792, whioh would inolude the ont1re saar valley. 89 France would thon, geographloully, and Industrial15. possese the saur Basin, which seome escential for Fronch Induatry. 30

The siret plen then was oridently to olaln the sear as beIng a sort of annex of Aleace-Lorralne if the boundaries wore establ 10hod on the 11nes of 2798. On January 9, 1918, Prosident w1Loon formulated a program in his Pourteon Polnts Address which was later aceepted by the Allied Powere, with reservations, Inoluding Trance, as embodying their atme in the struggle with the central powers. 32 The only referenee to the eastern frontier of France was contalned in tise elghth point whioh oalled tor the rlghting of "the wrong done to France by Pruesia in 2872 in the watter of Alsece-Lorraino."32 The Froneh attitude th the Peace

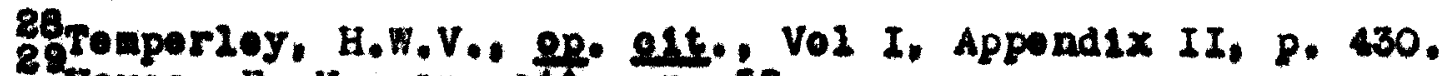
30 32 Thid.. $p$, 58 .

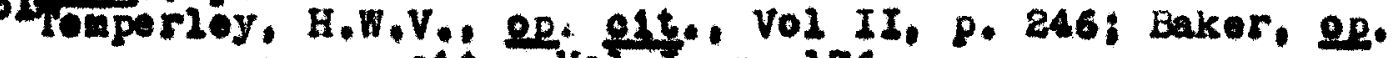
32 elt. Vol I, $P_{0} 276$. op. QLt.. Voi, III, Pp, $42-5$. 
Conforonoe, howerer, was Ioreahadowed on Dooember 29,2928 , in the Chamber of Deputies in the remarks of Frankiln Bouldion, Prostdent of the comnl ttee on Forelgn Afraiss of the Chamber. He sald In subetanoe "that Alsace-Lorraine in 1870 and the Sear constituted one question; that the taking of the Sasr in 2815 by Prusesia was a theft just as the taking of Alsces-Lorraine in 2870 was a thert; that the date was not important." 33

It was to be expested that C2emonceau and Tardieu, supported by tholr historioal and eoonomic experte nould oonduct a dipm lomat10 campaign for the Saar when the Peace Conference mot.

mon the Peace Concerence mot, Tardien prepared a momorandum based upon the studies of the question made by bis colleagues of the Concte d'atudes. This Homorandun was explainod and Interpreted to the Allies in numorous conferences during January and Fobruary. It offored a three-s02d solution: restoration to French sovereignty of the territories south of the frontior of 1814 ; a soctel political adalnistration for the territories of the mineral and industrial basin north of this frontier, full orneroblp of the mines in these two zones. This Monorandun was distributed in Maroh to the heade of the delegatlons at the Conterence. 34 Thle was lo2lowed ahortly by a verbal presentation of the French case to the Counoll of Four.

March 27, three days after the roturn of Prosident W1180n from the United States, Clemonoenu sont to Prosident W1Ison, Lloyd Oeorge and Colonel Howe his statement of the Fronch position on the

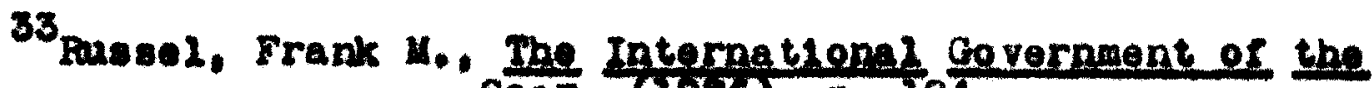

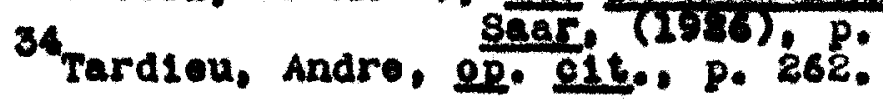


problen of the Bhine and French seourity. The note malntained the neosesity of separating the left bank of the Rhine, in a politioal and coonomic sonse, fron the Beich, and eotablishing the military occupation of the Fhine by an Interallied foree. The Frenoh, holl-ver, would yield thoir demand for permant oeoupation and agree to a date boing set for ovaouation (prosumably after thirty yeare), provided (2) that the left bank be oompletely demilitarized as well as a zone eifty k120motres east of the riveri provided also, (B) that the Allies through a permanent coaminaton of isspection rotain the right to eupervise the execution of conditions by Gormany, and (3) that Franod be given the right to ocoupy tho Fhine in case of non-fulf 121ment; prorlded aleo, (4) that Franoe be granted her olalw in the saar and provided rimally, (5) that oroat Britain and tho United states agree to consider as an act of aggreseiton any ontry of the German arny into the demilitarized zone and in weh case to bring military atd, 38

Loyd George and President Wilson were firm In thoir oppoitition to a thirty-year ocoupation of the Rhine zands and tho" President refused to approve French annexation of the saar. 36

On the corning of Haroh 28, Tardieu and Ho Louchour presented the case rerbalizy to the Councll of Four. After the opening negotiatione $1 t$ became clear to the Frenoh that determined op position would be enoountered from Presldent Filson. Lloyd Ceorge seemed somewhet more oompliant, although be Inolsted on 36 seynour, Charles, ep. att., pp. 393-4. Ibid. p. 395. 
oome kind of autonony, accompanied by eoonomie juetice for Franco? On Maroh 28, 2919, after W11son agreed to the Traaty of Guarantoe with changes, the Franoh delegates brought the question of annexation of the Saar in the Councll of Four. Lloyd Coorite rosolutely opposed 1t. President 118 on wa oqually hostile urgIng that Iranoe had norer advanced wach a claim besore. 38 the also reminded Clemenceal that Franee had already been given the rioh mineral diatriots of German Lorraine and that the repais of the wrooked Nord and Pas de Calals aines was only a question of time and money, the lattor to come out of arman pookets. He was therefore w112Ing that Franoe should have the output of the sear mines for a speoctied time, but of frontier ohanges and ennexation he would not hear. 39

President w1loon aeserted "that no one had ever heard of the saer until after the Armistice," and Clomenceau rejolned w1th an Intimation "that the Prosident latd bimeolf open to the charge of promGermanism and a hint that no Frenoh Prime Uinister could 1gn a treaty which did not atisfy Franco's claim to the Saar." "Then if France does not get what he wishes," sald the Pres1dent, "abe w111 rofuse to act 1th us. In that ovent do you wish we to return howe?"

"I do not wioh you to go home," sald clemenceau, "but I Intend to do 20 myeelf," and left the house, 40

3 3gouse, E. M., op. att., p. 39. 39 Tardieu, Andre, op. c1t,. p. 263. garbutt, W.. The Eear Territory. (1933), p. 20. Seymour, Chas.. op. elt., P. 396. 
President $71200 n$ was considering the fate of Flume in connection with the future of the saar. 41 The losue was corplieated. The Intelligenoe section of the Amerioan Commission preparing material for the negotiations, farored the transfor of the major portion of the Saar to Franoe.42 They admitted that the additional coselon would transfor to France a Cermen-spoaking population of about 355,000 people, who had hown no desire for union with France, but beld that the present dealres of these poople should not prevent a just diepesition of this important coal dosposit In faror of a sountry whose linited ooal oupplies had beon reduced by unlicensed derman expleltation and destruction in the mar. 43

The Amerloan expert, Haskins, who took the oh1ef part in these reoomendations, held the v10w that "the control of key deposits of mineralo by amall population which happens to $21 v 0$ orer them 18 not a necessary part of the prinolples of seltdoterwination, partioularly when this population forme part of a state whioh has been destroying the mines of others. The separation of mines from people may sometimes be governed by 1nternational considerations. "it

Prosident W11mon was adamant in his opposition to the transfer of several hundred thousand Germane to France. He stated, "I as willing to give Franoe any Indenenty in kind to which she is

$$
\begin{aligned}
& \text { 42Baker, R. S.. OD. 214. Vol 21, P. } 59 . \\
& \text { IFId.: } \mathrm{P} .73 \text {. } \\
& \text { 44h0use, s. H., gp. Qth. p. } 56 . \\
& \text { thaking, op. altes p. } 241 \text {. }
\end{aligned}
$$


ont1tied--I have no right to hand over to hor poople who do not want to go to her, or to give thom opecial government, even 12 1t is bottor for thom 18 they do not want 1t." seoing how his whole program of peace terms was at stake, he coneluded, "You s0e, I have to be firm on these polnte in all places, or I cannot hold out againet the exorbitant demands of the Italians, 45 Mareh 28, House asked the President, "to bring his position on the Frenoh (saar) boundary proposals Into barwony with the British. The Britich and oureelve are practically in agreement, therefore It would be a taetioai mlateke to have the Undted states take atand in whioh the was not supported by Great Britaln. I advised yielding a 21ttie in order to seoure barmony so that the coousation could not bo made that we were unreasonable. He promieed to do this." 46

President wilson accepted the ralidity of Frenoh olatwa to coal from the saar, and was carly convinoed that tho ownorohtp of the mines was the surest method of noouring just conpensation, but he did not admit the justice of political annexation. It was then polnted out on behalf of France there would be extrome diffieuztios if the minos, upon which at least onethird of the pepulation depended, were in the hande of one authority wh120 the government of the country wae oontrolled by anothar. 47 Loglealiy some kind of Frenoh soverelgnty or

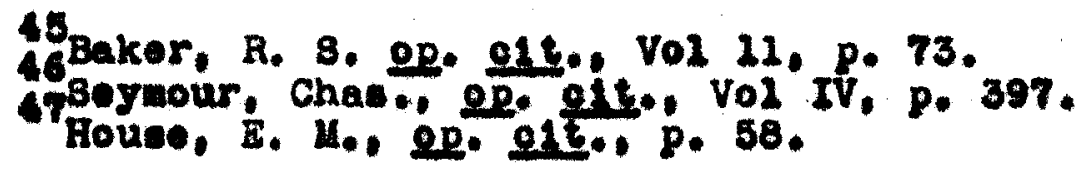


at loast tomporary athority ohould I0llow.

Prosidont F12son proposed a comalseson of arbitration to ecttle disputes ariolng in the Baar within the Gerwan Roloh. France refused, and propoeed soheme of coonomio and admin1strative unlon with Franos, allowing the people, distriet by distriet, the option to roto for Erenoh nationality at any time, and at the end of fifteen years, if any seotion of the people remained undeolded, they would have a Inal opportualty of roting themoelves in or out. 46 pifforenoes continued and becane more aeute between the Amerioam and the Fronch. "The problen of the saar Basin," eald a Fronoh delogate, "wan ono of those whloh the Ameriean delegates to the Poace Conforence and the United

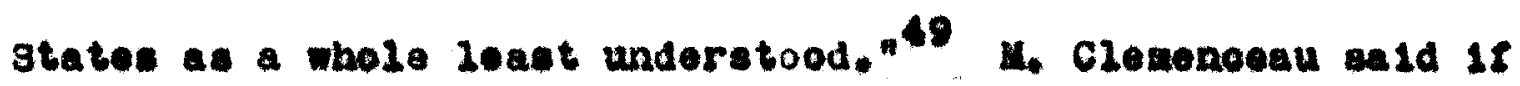
thoy were not oareful the sear would beeone a suropan Horocoe -m ho hotbed and toreing ground for continual Franco-derman oop1110ts. 50

Lligd Ceorge was w1112ng to adnt the prineiples of the tranefor of the saar mines to France as compeneation for the destruotion of her own ines. But ho stronuously opposed the annexation of territory which be belleved to be thoroughly German. Lot us not renow the mistake oomitted by Gernany in 2871 in the name of slotitious historioad right. Do not lot us create a new Aleace-Lorralno," he asid, 51

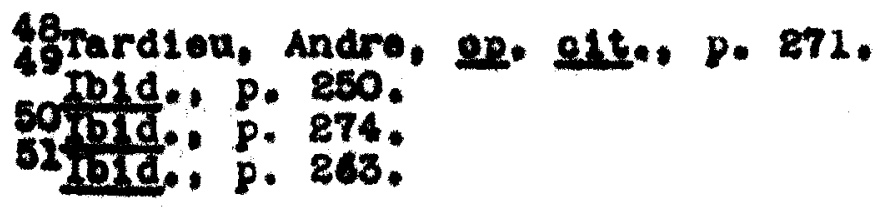


In the diseusesons of the saar question both the afore-bentioned statosena made it olear that from a national rienpolnt thore was no sacr question. 58 It was to mot this view that Clemencean geve utterance to the wyth that there were 250,000 Fronohmen residing in the saar Territory. 53 after 61 ve yoars of Frenob onnerabip of the mines and the introduction of manerous Trench offlolals and workmen, the Frenoh realdent population was found to be only 12,000 . 54

The Fronoh sabow for annoxation was 1 inalily turned down at the weeting of the BLg Three on Haroh 88th, when the olach oam betweon $\mathrm{M}$. Clemencean and Prosident flizon. 55 Attor the meeting Lloyd Oeorge invited tho Britiah Forelen Offion to prom duce alternat17e sohomes, Three proposals were made, cae seature of all three was the ownerahlp and control of the mines by Franoe. Onder swo of the sobowes, whlah raried allghthy. France was to reeelve a mandate to adminieter the Territory under the Loague of Nations. The third sohome was to oreate on independont saar Bepub210, with a custous union with France. 56 Tardion was buey at the same time with another proposal. In the meantimo wiokham steed was at work on a forwla for President wizeon, whioh was not subaltted, however, unt11 Apr12 2at. 57

Prealdont Wilson began by rejeoting the Frenoh olain in

53 geymour, Chas. ep. Alt., Vol IV, P. 396.

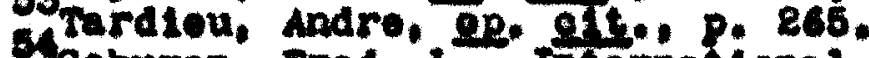

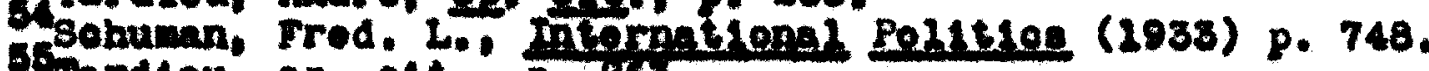
567ardin11, ne, elt.. P. Lbb.

Strid., p. Eri.

57bonaid, sir Robert, A Dangeroue Spat In Surope, (2925), 
toto. He was not won by any of these plane nor did he suecumb to H. Clemenesa's touching appeals, He held his ground to the breaking point.

Prealdent w12son insisted on the fact that the frontier demanded by the Fronoh in thoir earlier offloled pronouncements was reparation for the wrong which he surfered in 2871 and not in 2815. Ho saw in the new demand of Clemonoeau, a violation of the principlos expreseed in his Fourteen Points, which were the accepted basis of the peree negotiations, 58 It seemed for a time that there could be no possible way to reooncile the conflicting views of the Frenoh and Prosident Wilson. In the Course of disouseion Clemencealu made, on March 28, h1s celebrated statement about the 150,000 Fronohmen 21ving in the Sear who, in 2928, had sent addresses to President Polnoaré. Ho demanded that their righte should bo proteoted as well as those of the Germans. 59 For a timo Prealdent wilson refused to jiold. The Peace Conforenee had thon to pase through one of Its gloonlest moments. M. Clemeneseu stated that "Prosident M11son implores us not to make the peace of the world depend upon the Saar." M. Clemenceau roplind, that "peace of the world demands, elrst of all, that juctice be oxtemisthed among the allien."

Waroh 29, the Frenoh Prime ulniater ent Tardiou to Colonel House, who asked Hackine to work out with Tardieu a solution of the saar problew that would assure the Frenoh unhapered control

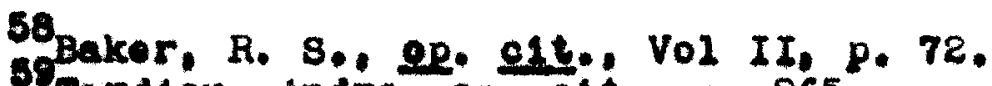
s9ard1ou, Andre, op. alt." P. 265. 
of the coal mines as falr roparation for the damage done to the Frenoh mines, but would not tranefor a large cermen population to French coverelgaty. The President was alow to agree to the suggestion upon whioh Hagkins, Tardieu, and Headlan Horley, roprosenting the British, I1nally settled: that a spoclal adminiotrative and political regine must be applied to tho dietrict. so as not to interfere with Frenob operation of the mines, ${ }^{6}$

Apri2 R, the President asked House if the solution proposed by the experts and which clemenceau alght bo wliling to take as to the Saar Valley was Ineonsistent with the Fourteen Polnte. House repl1ed, "that there were many who thought otherw $180, " 61$ On April 6, Ray stananard Baker, Chler of the Prose Service, was particularly active in spreading peseluitetio reports, He apeuped Clemenceau of "claiming annoxation." President Milson became diseouraged. The hour was or $1610 a 1.62$

On Apr 12 7, It was rumored that Prosident H1Lon had orderod the "George Wash1ngton" to Brest. The aotion fell 21ke a thunder bolt, It was so unexpected, so challensing, so tinal, that balf the newepepere wowld not at first believe 1t. Our press bureau wae directed to make the bare announcement without explanat1on. But no explanation was necessary; it was olear to -veryone that the President had reached the extrome limit of his pationce. The effect was astonishing after the first outburat. 60 IbLd.. p. 396.
61 Tbtd. p. 397.
Ibld. p. 872. 
of agitated oommont it produoed a suddon hush in the world. For - time the oritloien in surope almost completely ceaced.

On Apr12 8 appeared one of those extraordinary 21tt2e 1tens in "Le Temp" whioh overyone rooognized as a kind of rinal deolston upon a great polloy. It was headed: "France's clales," and was as lollows:

"Contrary to tho ascertions sproad by tho Gorman prose and taken up by other foreign newepapars, we believe that the French Government bas no annexationiat pretensions, openiy or under cover, in regard to any territory inhabited by a corman population. This remark oplies partioularly to the reglons ooppriged betwoen the frontier of 1871 and the front 10r of 1814, $" 63$

This latter rogion was the Saar Valzey, and this statement symbolized turning point in the Conference. There was an inmediate toning down of the demands, and now effort on every hand to get together. Above all, there was a marked change in the attitude of the Press toward President wilson. Hils bold gesture had oleared the alr, and from that moment forward the progrese was wach more rapld and deossive. 64

On the morning of April 8, Lloyd Coorge suggested to the "Counoll of rour" that the sear Valzey should not be annexed to Franoe, but should be formed Into a neutral state, 'a klnd of Luxemburg..... Hould make this distriot bigger than the saar valloy, onlarging it so as to bring in the industrial seotion upon whlch the saar valley depended.... He would make It an independent state in the oustome union of France with its 63Baker, R. S., What wldeon D1d At Par1s, (1920), p. 66 . 201d.: P. 67. 
own Parllament. 05

House was not greatly taken w1th this plan, although ho agreod that if the aggested state woro placed under the protection of the League and not economically united to France it should be considered. In the afternoon, fresident Nileon returned to the council and rofused absolutedy any allemation of the saar from Germany. Ho would concede the minos to Erance, and weot the difficulties cortain to arise from cerman ownership of ths so12 and Fronch osnership of the sub-so12, by the inetitution of a mixed Commission of arbitration. 66

On April 9 Clemenceau distributed another note to the haads of delegations in whioh they labored to show that an arbitration comasion would not provont conflicts from conatently arising between Germany and Franoe and that it would uaber in a "regime of porpetual Lawsut ts." They therefore las lsted that German soverelenty mat at least be suspended for a period of fifteon years, and a peolal politioal and adminietrative regime established.

Despl te Lloyd Beorge's approval of the French position, how-ver. President Wilson found it unaoceptable. In the afternoon of the same day ho adranced an alternetive plan for the government of the region for fifteen years by an International administrative commiesion. 67 On being ase ured that German sovere1gnty in the territory would bo suspended during this period, that 65 seymour, Chas.. ․․ ㅅt.. Vol IV, p. 405. 66 Told.: p. 405 . 67Tardieu, Andre, op. c1t.. pp. 272-6. 
the Commisaion would have full power, and that the Inhabltants would no longer be represented in the German felchstag the Frenoh acoepted the plan in princlple, 68 and agreed to leare the detallo to the committee of three, already tontioned. 69

The plan, Inally aocepted, was to hand oror tho coal-winea, which had been the property of the Prussian Government, to Franoe as some coapensation for losees in Northern Franoe and to plece the government of the Territory under the League of Nat1ons. 70 The Counc12 of Four accepted Apr11 10 the draft of olauses made orernight by the comatteo of experts, which gave Franoe at least a favorable prospet of obtaining what ahe wanted in the Saar Valley.

In acoordance with their report, Wilson's proposed commission of Arbitration was converted into a cominsion of Admin1stration under the League. The ultimate destiay of the territory. as a whole or by distriets, was to be deolded by the Loague in acoordanoe with a plebisclte to be taken after fifteen years. The latter prorision was the nore willingly acm oepted by President WILon because it gare the League of Natsons something Important and Immediate to do. 72

A treaty was drawn that gave full consideration to the chlef French olalme. The auggented basle for agreement was carried beoune all progreas in the drafting of the Poace Treaty threatened to be stopped unless Ingland and Amerlca gare way.

68.1.d. p. 276. 69 touse \& seymour, ag. cle., p. 59. THouse, E. M. op. Ale. p. 60. TI Tardieu, Andre, ep. elt., p. E76. 
The compromlso was aceopted, although it did not sat1siy President wileon. "The time hes not come," sald the president in confidence; "we eannot risk broaking up the peace conterence yet." The League however was being rashloned. The saar was to be 1 te tiret charge. The future walfare of duropo wes involved in the settlewent. 72 It was not foreseen at the time that the oompromise left Europe with a new problem.

The drafting of the terms that doterminod the Bear settiement was placed in the hands of a comittee which consioted of representatives of three oountries only, namely, Andre Tardieu for Franoe; Headlam Morley for England; Prof, Chas. H. Haskins for the United States. Tardieu presided with the resouroefulness and ak111 which he brought to all matters of the Conforenoe, and the final draft of the treaty articles was tine unanImous work of the committeo. It was alded by specialists, such as geographers, mining experts, and legal advisers, On the American side the work of Devid bunter Hiller was all importent at critical points in the negotiations, as regards not only the drafting of pealfio clauses, but also in all larger questions connected with the new form of government. The determination of certaln questions of boundary was feolliated by apecial visit to the distriot. 73

The starting polnt of the committee works was a statement formulated on Maroh 29, by Hoadlam, Morley, and Haskins, with

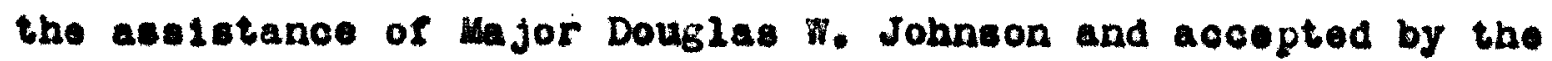
${ }_{73}^{78}$ Baker, R. S., op. c1t., Vol II, pp. 39-40.

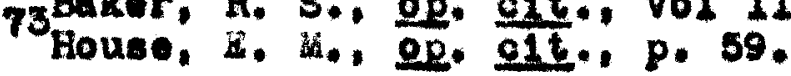


Counoll of Four.74 By th1s it was agroed in prinolple that suld ownorahip of tho coul minos of the sanr Basin should pase to France to be oredited on ber olalms against cermany for reparation and that the fullest economic raollities chould be acoordod for thoir exploitations, while the political ond administrative arrangenent necesary to secure these reaults should be the subjeot of curther Inquiry. ${ }^{75}$ The draft aubmitted to the Counctl of Four, who acoepted 1t, became 3ec. 4, fart 3 of the Treaty.

There was another difficulty encounterea when the Treaty was handed over to vermany to s1gn. One of tho most powersul polnts of attack by the Germans was the Saar Valloy settlement, both on the ground that it offended the princifle of solf-determination, and that ite coonomle aspects wero botit unjust and unworkable. There was a provision la the draft tresty by whioh - tinal voto of the population of the Sasr for Germany was to be erfective only if she wore abie to redeen the coal mines from Franoe with their value in gold. The German attack was - ffeotive and a new proposal, arawn by the saerican kxport, Haskins, was accopted on hisy $24,^{76}$ It was practicelly the only change made in these oections of the Troaty. Cermany was given the assurance that no obstacles would be interfoged to prerent her repurchasing the Saar mines, should the Inhabitante eventualif deelie for German soverelgnty, 77

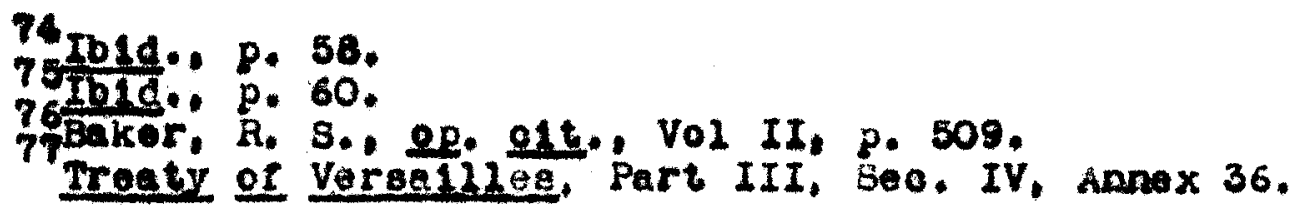


In criticizine the saar settlenent srom the point of viow of reparation, the Germane argued, Just as the American oconomic oxperts had done, agalnet the bodily transfer of the Saar mines to France and proposed lastead to make fixed doliveries of coal to Franoe a a substitute. 78 The offer, however, was vague; and 1t did not, after all, meet the cruclal french demand, which was more for seourity, both immodiate and in the future, than for reparation.79 As Haskins, the Amerioan Expert sald, "A wine in hand is worth many contract. to deliver." 80 Acoordingly 1 th was agreed in princlpal, 2ate in itarch 1919, that the full ownerenlp of the coel mines of the sear Basin should pase to France, to be eredited on her elalus againet cormany for reparation. ${ }^{81}$

With sull and unenoumbered property in the mines tho troaty gave the fullest eoonomic fac121ties for their oxploitation, Inoluding the acquisition of all subsidiaries and dependenoles, freedom of traneportation and sale, exemption from other than looal taxes, and full noblilty of labor. 82 The mines wore pleoed within the French oustows unton, and payment in connoction with their operation alght bo made in French money. 83 At least this muoh reparation was assured to France and in a form absolutely essentlal for the revital of her wrooked industries.

The problem as rar as the poace-makers were concerned, was

78 Baker, R, 8, og. 21t.. Vol II, P. 509.

79 Iuid.: p. 510 .

Bithakins and Lord, 2p. alt.. p. 243.

Gersallies Ireaty, Artiole 45.

6 ibia.

B3 I010.. Par. 31 . 
-olved in prinoiple. The self-determinists ald not like it, but they consolod themselres with the thought that, after all, the saar would be better off under the contemplated rale than it It had beoome an oecupled area, which would otherwise hare been 1ts fato, with French owning and working tho coal mines, and as for the undenocratic character of the proposed government, 1t was, after all, only a temporary arrangement auring whioh cerman soverelgnty would be in suspense, the fate of the poople being in their own hands arter fifteen years. 
C HAPTER I I

THE TREATY PROVISIONS 
THE TREATY PROVISIOAS

The provisione governing the saar Basin constitute a separate seotion of the Versallies Treaty, Section IV of part III, oompriaing Articies 45 to 50 , together wth an Annox which 18 subdirided Into three chapters and forty paragraphe. For the totality of these provisions the nawe "Sear statute" has been colned. Articles 45 to 50 of the Treaty contain the general principles of the saar settlement, the objects of the latter and a desoription of the boundaries of the newly-oreated unit, The detalls are set forth in the annex. The three chapters of the annex deal with the oession and explo1tation of the mining property, the government of the territory of the Saar basin, and the plebiscite.

As compensation for the destruction of the coal mines in the north of France, Cermany was forced to cede to France the full and absolute possession of the coal mines situated in the saar Basin, unenoumbered and free erom all debts and charges. 1 As owner of the coal mines the French atate was expressiy recognized as having complete liberty not to work as well as to work them. ${ }^{2}$ If 1 desired to transfer the right to work the mines to a third party the Treaty sanotioned it; if it wishod to Import workmen from outside the Territory for the mines

Ireaty of Versa11les. Part II, Sec. IV Art. 45. IbId.. Fart III. Sec IV Annex Par. I. 
and their accessories, It might do $\operatorname{sog}^{3}$ and it was to enjoy oomplete liberty to determine the distribution and price of the products of the mines and thoir acoessories and subsidiaries." The right of ownerablp of the Frenoh state applied to all coal mines In the saar, no matter whether concesslon were grented for them or not, whether they were worked or not, and irrespective of their previous owners. It also extended to all the accessories of the minos, Irom the extraoting machinery to hospltals and schools, and to all outetanding claime. 5 The ralue of all this property was to be determined by the Reparation Commiselon and was to be oredited to dermany as part of her reparation debt. ${ }^{6}$ A number of provialono were Inserted with a viev to giving the Fropch state a maximun of liberty in working the property; while others were desisned to grant France certain privileges as agalnat the Governeant oet up by the Laggue. Thus, the Fronch state was given the right of - tablishing primary or teohnical sohools for 1 ts employees and their ohlidren, ${ }^{7}$ obrlously relating to the Eronch miners who would sottle in the Saar. Schools in which French was the language of Instruotion were naturaliy laoking in the Sear. On the other hand, the Fronoh state was to contribute to the $200 \mathrm{l}$ budget of the saar Basin and to the munlolpal rates and oharges, with due rogard to the ratio of the value of the mines to the total taxable wealth of the distriot.

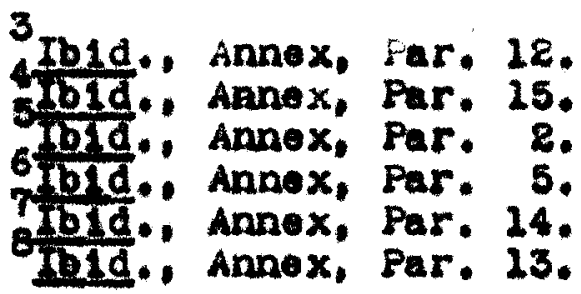


"In order to asaure the rights and velfare of the population and to euarantee to France complete troedon in working the mines, ${ }^{9}$ Oermany had to transfor the governwent of the sear Bas in to the Lague of Nations acting as truetee. 10 The Lageue complied with this provialon by appolnting a Governing Comission of the sar Basin, consisting of $\mathrm{l} 1 \mathrm{ve}$ memers, 21 whose doric1le was at saarbruoken. Its mbera were nominated by tho loague Counc12 for a term of one year, but could be remppointed. Mombershlp had to Include one Fronohmen and one native Inbabltant of the Saar not being oltizen of France, while the remalning members had to belong to three countries other than Franos and Germany. ${ }^{2 E}$ Thus Germany was not represented at all on the Combission. The chalrman of the lattor was appointed from among 1 ts menbers by the Counc1l of the Lague for one year and was 21kew1me subjoet to re-appointment. He acted as the oxooutive of the comission, whose declelone were taken by a mejority. ${ }^{13}$

W1 thin the Saar Basin the Governing Commiest on exorcised all the powers of government previousiy rested in the Cerman Bmpire. Pruesia and Bavaria. 24 It had the evil right of user of all the property sltuated in the Saar Baeln formerly belonging to the Government of Germany or that of any German federal tate, except the mines. ${ }^{15}$ on the excoutive and adminiatrative side it also had sull power to appoint and diswles offleials, to administer and operate rallways, canale, and the different public services, 16

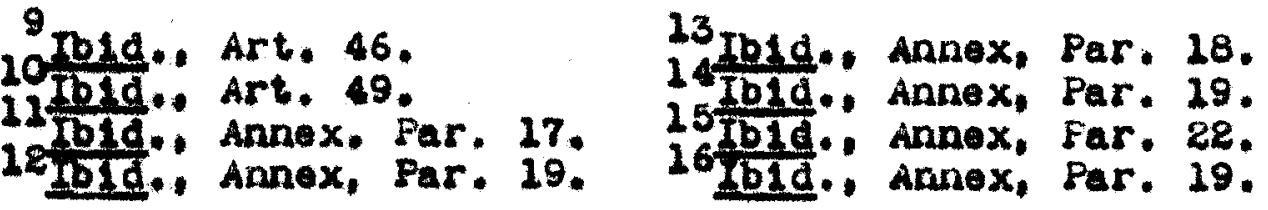


and the power and duty of providing for the protection abroad of the interests of the Inhabitante. 27

The leglelative powers of the Comalsaion Included the creation of administrative and reprosentative bodies at diseretion; ${ }^{18}$ the power to modify mining legialation in torce in the Territory after conaultetion with the French state; the power to efrect modIf loetions in the laws and regulation in force on November 11, 1928, In the Territory, after consulting the elected ropresentative of the inhabitante; the power to $I \mathbf{L x}$ the oondition and hours of labor of men, women and ohildren; 19 and the sole power of levylng taxes and dues, 20

The judielal funotion were lett to the existing oivil and oriminal courts. A supreme court acting as a court of appeal. was added to them and this court had original jurisdiction in matters "for which these existing courts are not cowpotent." 21

The nationality of the inhabitants of the Saar Basin was in no way affeoted by the tipulatione lald down in the Saar statute? The Inhab1tants of the saar Territory might belong to different nat lonal1ties. Par, 27, of the Annox states "that no hindrance thall be placed in the way of those who wish to soquire a differont nat1onality. "2s There 1s no doubt that the Idea of "1nhabitant of the saar Torritory" should be extended to all those persone, without dintinction of nationality, who inhabited this Ter-

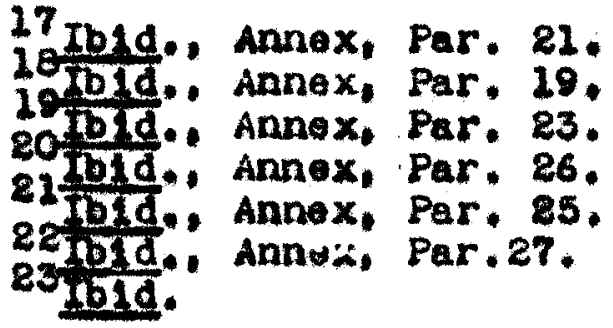


ritory. Howerer 14 was necessary te $f(x$ procise rules laying down upon what oonditione and by means of what formal1tien a pereon can be admitted to the enjoyrant of the status of "1nhabltants of the sear Territory."

The decree defining the term "Inbabitant of the Territory or the Saar Basin," reoognized persons born in the Territory and those resident in the Territory on November 11, 1918, as 1nhab1tants "by right." Other porsons might eoquire the status by residing in the Territory for a period of three years. This perlod of residenoe was reduoed to one year, however, in case of publio offiolale and others who could prove that they hold - "position whioh requires that their main residence be in the Territory of the Saar Basin. "24 Any person residing in the Torritory but not onjoying the atatus of "inhabltant" was henceforth to be considered a forelgner.

The Ooverning Commisaion stated it had in mind the aseuranoe of equal righte to all the Inhabitants of the Saar; that those of Oerman mationality had anjoyed "oonsiderable pritileges in oomparison with the nationals of other states;" and that 1t considered it necessery, therefore, to provide that nationality should ne longer be a binarance to the inhabitants of the saar Territory, and that the logislative provialong in force whioh conflioted with this prinotple should bo withdrawn. That German natlonals who did not posases the status of Inhabitants of the saar should be considered as aliens within 1 ts boundariea was only an ineritable oonsequenos of the provistons of the Treaty 24.1010., p. 842 . 
of Peace. 25 Under the control of the Corerning Comission the Inhabitants wore to retain tholr local assemblios, tholr rel1glous 11berties, thoir sohoole, and their language. 26 Militury service, whether compulsory or voluntary, was prohlbited throughout the dietriot; and only local gendarmerie for the alatenanoe of law and orcer could be establishod. 27

The flucal yoten existing on November 28, 2928, was to be meintained, and no new tax exoept cuatome duties might be $1 \mathrm{~m}-$ posed whthout prevlously consulting the elected representatives of the inbabitante. 28 customs duties were excepted because the saar Basin had been Inoorporated w1th the French Customs yyetem. 29 Unti2 November 21, 1928, the Saar Torritory, AlsaceLorra1ne, and Luxemburg were under the German oustons admin1stration. The mine and netel working establishments of the Territory exportied the greater portion of their products withIn th1s ame oustoms zone. The Armistioe Convention however, In the first place, and the tho Treaty of Peace of Versallies, placed Alsaco-Lorraino, Luxomburg and tho Saar Basin outsluo the Berman oustoms unlon. There was therefore no customs barrier between the Saer Bas in and Lorralne fros which it obtained 1te Iron ore: nor botween 1 tself and lts former customors in Alsace-Lorralne, 30

Because of the inexpediency of an immediate and complete

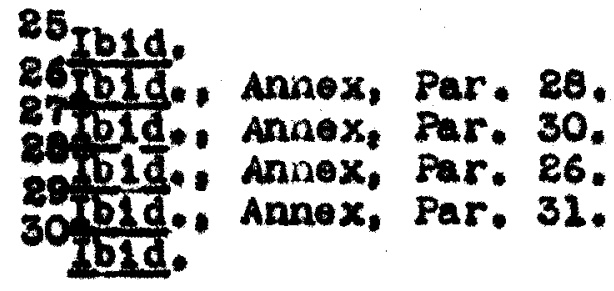


conomic severance of the saar from Germany or even the erection of unacoustomed economio barriers between the two sectal provisions rogerding oustoms were to be in force during a traneitory period of 11 ve years. (1980 to 1925). 31 During that period no export tax might be imposed on coal and motallurglcal products exported from the Saar to Gormany, and 11kowise jerman imports for the use of the industries of the sear were not subject to an Import tax. 32 Natural or manufactured produote originating in the saar wore not subject to oustoms duties in transit over German territory and producte coming from cermany were not to be oubjoot to traneit charges over the saer. ${ }^{33}$ No prohibition or reatriotion was to be Imposed upon the circulation of French money in the Saar Basin. 34

The Gorerning Commission was the legal authority for the protection of persons and property in the Sear besin, 35 and 11kew 1 se the protection abroad of the 1nterests of the inhabitanta of the saar. 36 Any of the Inhabitants of the Saar who desired to leave the territory had sull liberty to leave behind the ir Immorable property or to sell it at feir prices, and to remove their movable property free of any charges.37 The coverning Commiseion was obligated, through the local rallway administration, to provide equipment and personned necesery for the transportation of the products of the wines and their accessories and the

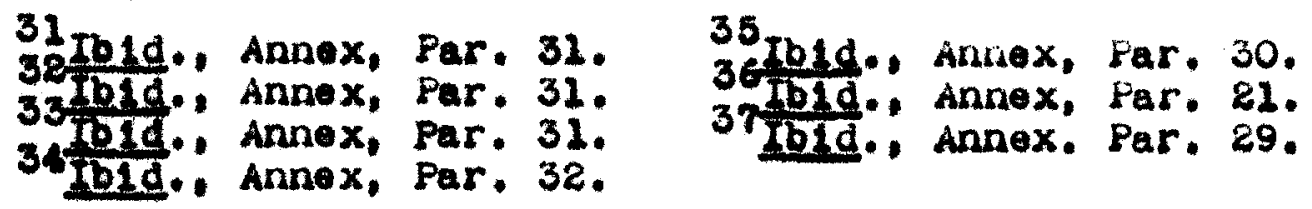


employees and workmen of the French state, 38 and, 21kew18e, no obstacles were to be placed in the way of the Improrement of any of the raliways or waterways $1 f$ deemed neceseary for the transportation of the products of the mines. 39 The employees and workmon of French nationality were to have the right to belong to Frenoh 2abor unlone. 10 Tinally, the Commlesion was to have power to decide all questione arleing from the interpretation of the ecoond chapter of the saar statute, Including those concerning differenoes of opinion betweon Germany and France. 41

At the termination of a period of 1 ifteen years from the coming into force of the Treaty. (January 20, 2935) the population was to be palled upon to Indicate 1 te desires regarding future status. 42 For this purpose a ploblsolte was to be takon by communes of by dietriets on the three following alternatives: alntenanoe of the regine established by the Saar statute; union with France; or union with Germany. 43

Al2 persone more than twenty years old at the date of the roting, resident in the territory at the date of the signature of the Treaty (June 28, 1919) wore to heve the right to vote. The other conditions and partioulars were to be Ilxed by tho Counoti of the Lague of Nations in such a way as to seoure the freedom, secrecy and trustworthiness of the roting. 44 The League was then to make a derint te decision ooncerning the territory, taking Into account the wishes of the Inhabitants ex expressed

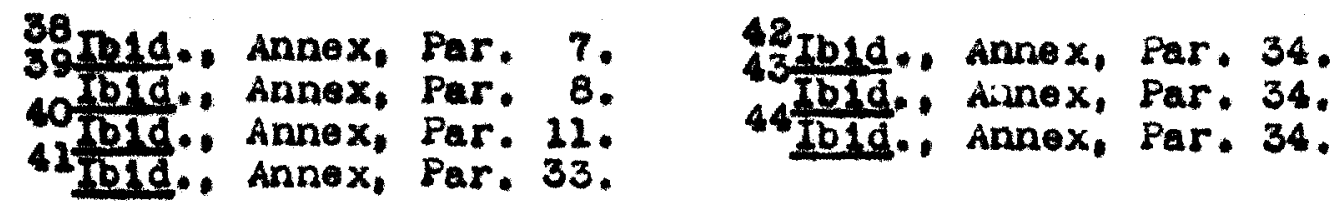


by the voting.45 If, In conformity with the plebiselte, the saar was reunited with Germany, Germany would have to repurohase from France the coal mines at a price payable in gold to be determined by a committee consisting of three mombers, 46 and France would be entitled to purchase ae much saar coel after such rounion as aho might require. 47 It was expressly provided that Gormany and France might oome to a different underetandint concerning the mines and that they might modify the provistons relative to the repurchase of the mines and the subsequent $8 a 2 \theta 8$ of saar coal to france. 48 


$$
\begin{aligned}
& \text { CHAFTER I I I } \\
& \text { ECONOUIC DEVELOPUENT }
\end{aligned}
$$


ECOHOMIC DEVELOPUENT

Natione have quarreled about eoonomio mattere from time Immenorlal, but it is only in comparatively recent years that mineral resouroes hare become an laportant caus of war. The reason for this is simple. The world is juat boginning the intene Ive use of these resourees. The curres of production indicate that a greater rolume of mineral resources has been used sinoe 1900 than in all the preoeding reoorded biatory of the world. 1 Within this short time the question of the possession of these resources has changed from one of Inoidental coneern to nations to one of vital ingort to their prosperity and even to their existence. It 18 beooning clear that the antion without control of certain eseential minera2s, suoh a ooal, o11, and 1ron, can look forward to a position of inferiority, both in war and in poaee."

Whether it 18 right or wrong that coonomio considerations of this kind should play a dominating part in international arfalre 1e another quettion; thelr influence is here merely recorded as a faot. It ma be safely aesumed that the international 1 aportanoe of mineral reeourees w112 gron rather than

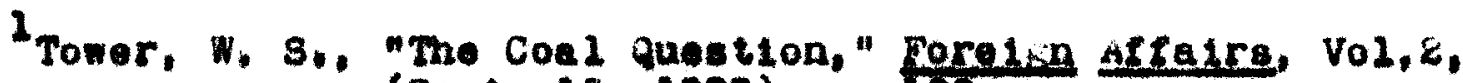
(Sept. 15, 1988), p. 100.

8smonds, Frank H. andimery. Brooks, The Great Powers In World Pol1tiag, $(2935), p, 67$. 
Awindze. 3 Reonomic power in the twentieth century is as Lapertant a faotor in war as in man-power. 11 not more important. 4 Therefore, soonomie atrength was one objective of Frenoh polloy. Jerman superiority in this respot would be as great a nomee as her auperiority in popazation. France must here, therefore, pursue the eame polioy as in her military, diplomatie and polit$10 a 2$ plans, add to her own ocononte strength and reduce that of Derman.

Thare are three main geogrephis und ts of the iron and steel Industry. By "unit" is meant the whole notmork of $150 \mathrm{n}$ mines, coal minos, tranaportation 1ines, water and rall, blast furneces, steol plants, fintobing plante, factorios using iron and steel produots, whloh goes to make up each of the prinotpal googrephic groups in tho iron and steel busines:. The firet unit is in the United States: tho oecond in Bnszand. The third group inoludes German, France, Belglum, Luxemburg. The ereat 1ron ore supply of Continental Burope is oentered in North Eastorn France, Inoluding Lorraine, and overlape into Luxomburg. The coel bede whioh furniah the coke for the smelting of this 210 mainiy in Weatphaila, in western Germany, with extensions into Belgium and Northorn Franoe. Tho detaohod saar Basin furniahes an inferior and relatively suli supply of ooke. The Iron and ateel Industry besed on those raw torials is 200alized prinolpelly in the region of the Cerman ood I1elds, Ith

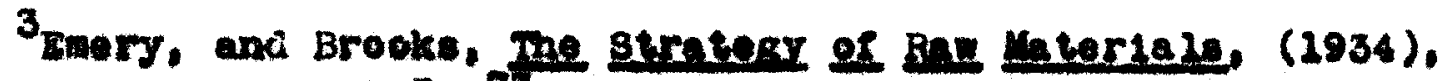
Foke 1. B. C. Coal. Iron and whe (2930), p. 67.

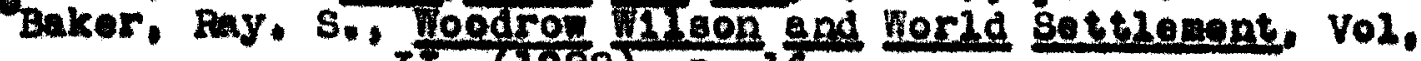
II. $(1982) \cdot \mathrm{p} \cdot 16$. 
subordinate oenters in Belglum, Northern and North-iastern France, and In the Saar Reglon. The valleys of the finlne and 1t. tributaries conneot the cosl and Iron ore flelds. The Industry is to be regarded as a single great unit, regardiess of natlonal boundaries. 6

The considerable economic importance of the saar is due to 1ts extensive induetrial activities. Among the coal-mining distriots of Cermany it holds the third and among the iron produolng and Iron-working oenters it holds the second position. After the Ruhr, the Saar Basin, containe more extensiro coal deposits than any other single diatriot in Wostern Continental Europe. The sear consists emsentially of a coal basin from which before the World War, Germany obtalned $\%$ of her total coal supply, or more than 27,400,000 metric tons. 'The teohnical inportanes of the sear coal is attributable to the Iact thet it is rery aultable for use as gas coal, boller coal and manufacturing ode1. On the other hand, it 18 less sulted for coklng coal, although recent teohnical innovations make tt posetble to ut121ze it for this purpose as we 11.8

The sear territory 19 also an Integral part of the FuhrLorraine Syetem. 9 The dependence of the Lorraine iron Industry on the Ruhr for its coke supply was specifically recognized in the Treaty of Versallies. Among tho most important

6Lith, C. K.. "World Iron and steel sttuations," Forelen 7 Aftelre, Vol. I, Mo, A, (June, 1983), P. 199. 7Bowman, Isalah, we yer Horid, (1928), od, p. 172. ow, Green, The Bohr-Lorralne Industriel Problem, (1925).

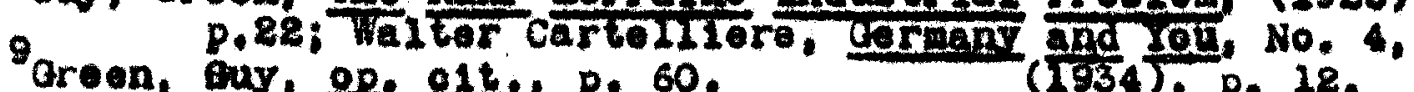


proviolons of that treaty was the atipuiation that of the coal deliverles to be made to rranes sor a period of ten years, ${ }^{10}$ a certain proportion, to be seolfied by the fleparations commisalon, was to be in the form of motellurglcal coke, in the ratio of three tons of coke to four tons of coal. 11 Thie atipulation was the result of a carefully considered plan on the part of the peace oonference to insure the continulty of the fahrLorralne syoten. 22 The Ruhr was the very hoart of German industry. produotas as it did elghty per cont of the country's coal, Iron and steel, and belng responglble for seventy per cent of 1to oomerolal railway trate10.23

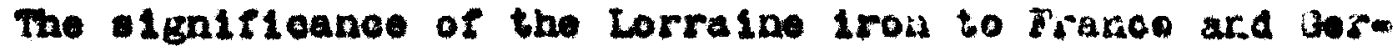
many before the war my be indieated briefly by a foll Ilgures. In 1913, of 88t a1111on tons of 1ron ore extrected from Gorman s011, over 21 allilon tons oame from annexed Lorraine. In the same year Germany Imported in addition 24 milizon tons of Iron ore Irom forelign countries, this 14 gure belng the annual produotion of the Briey F1elds. 14 In 2913, on the other hand, France produeed 22 atilon tons of 1 ron ore, but owlat to the deflcleney of the oountry in coel nearly half of th1s was exported. N1netenthe of the total ore of the country were rased in Fronoh Lorraine. ${ }^{15}$ How Iron has both an industrial importanoe and a

20 Yeras1lue Treak, Part VIII, Seo, 1, Annex, 5, Par, 2. 1276ta. Par. 7 . 130reen, ouy, ap, ctin. p. 95. 13Langeas, Walter C." me worid since 1924, (2933), p. 165. 14iowbicen, Marion. Aftermsth A Ceogrankical study of the 15 Bence itorge. (1920). p. 21 . pid. 
m111tary one. The Iron ladustry of ang country 18 usually taken as convenlent index of its laduetrial development, for all industries Involve 1ta use. Ageln, lto importanoe in war does not noed emphas1s. The posseselon of the Iron rielde of Lorrata is thus not purely an 2ndustrial question, elther for France or for Cerwany. In the hands of a military power they are of Infinite1y greater Importane tban any strategie erontier. Thls add a now complication, beds of Iron ore are of little use without ooal, 16

Trance as whole is poor in coal, a lact whioh bindered her full development of the Iron f1elds of Frenoh Lorralne, and nocossitetod the export of a larige amount of ors, muoh of whioh was weltod on the Nestphalian coalfield. The destruction wrought by aermany in her northern oodeleld dialniahed her output for Iive years after the war. This is tho reason given in the Troaty for the ceseston of the saar coalfieldy as we have seen. But, nost of the coals of tho Baar area are not sultable for coke prodvotion, and ooke is largely required in the meltiag industry. Thus hor possession of these flolds does not solve her Iron problem. ${ }^{27}$

Although tho saar has proctically no 2 ron ore it is only about thirty miles trom the Iron gines of Lorraine and as a rosult of the short haul to the ooal diatriot of the saar. cokerles have beon ostabliobed and great 1 ron and steol works 16 rbid.: p, 28.
17 Tbld.: p. 23. 
have grown up. 28 These motal works and other large taotories employ about 60,000 people, making a total of about 130,000 persons employed in the mines and in industries olosely connected with and to a great extent dependent upon them. 19 The iron-produeing Industry is represented by the metallurgical works at Barbach, DLLLlingen, Balberg, Nounklrchen and Volk12ngen. About $90 \%$ of the Iron treated by them consists of "minette" ore from Lorraine. There are other industries of oonelderable importanoe. The glase industry ranks next to motallurgy, omploying in 2913 sive thousand workers. It conPines Itself almost ontirely to the manufacture of tablo glase, hollow glass and pressed glass. The making of table glass is mainly in the hande of two large glase worke altuated at st. Ingbert. The ceramic industry pottery, porcelain, terra-cotte, mosato articles, the takes third place, omploying about 3,000 workers. The ceramle industry 18 chlefly represented by the worke of the world-renowned firm of V1lleroy Booh, the most Important establishmont of 1 to kind in Europe. Other minor Industries, employing altogether several thousand persons are the chonloal industry, explosive raotories and paper m111. 20 Among the minor industries of the Sear partioular mention must be made of the induetry of foodstuffe, beverages, tobacco, 18 Brooks, A.H., "Saar Digtrict," U.S. Deal. Surroy, Bull.

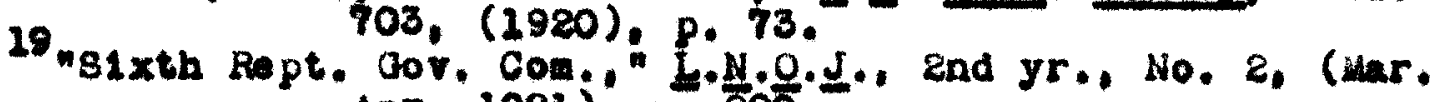

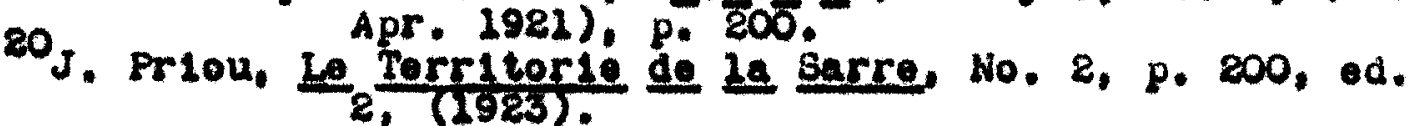


wood, 2eather, and the manuegture of surniture, shoos, text11es, soaps, and perfumes, all of whloh are soncentrating primar12y to supply domestic demands. With the oustome separation from the Roloh a mamber of now Industrial enterprises have 21kew19e dereloped, seolelizing in vartoue kinds of merohandiee manufestured in Oorman quality and taste. One of the most 1nteresting features of the esonomic aotivity of the saar is its handiorafts. There 18 also oomprobmelve banking business. A 02080 not work or ral2ways doals with a traffic comprielng $60,000,000$ puseengers and $80,000,000$ tons of Irelght annualiy. and approximately 20,000 motorized reblolos opeed orer the highwaye of the oountry. 82

The Iron working laduetry is represented by a large mamber of works turning out wachinery, Iron struoturas, cablevays, holeting and oxtrasting platis, ctoel construotions above ground, -toel bridges, sorews, stean bollers, llttinge and pumps. All the worke named exeept Halberg are of the mixed type i thoy prom duoe ple 1ron, rain steel and rolling-mil2 products. Among the -orke spocializing in verloue iron producte wention should be wade of the following: Halborg. (cest 2ron plpes and tubes); the Boohling refined-otteol worke at Volkilngen (rof ined stoel); the Mannosmann tube worke at Bous, (steed tubes); the Homburs Iron worke whloh aro affiliated to Nounkirchon, (steol tubes and permanent-way eorews)! and the st. Ingbert 1ron workn, (band 4ron, wire and wire producte). Altogother, thirty blaet furnacs were used for the purposes of the 1ron-produeling Industry,

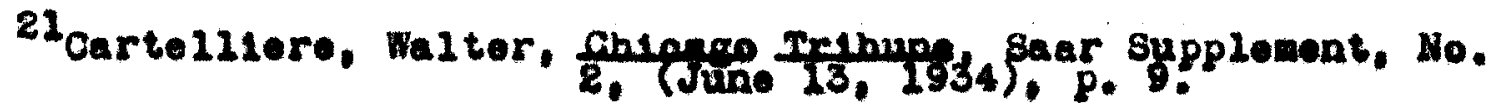




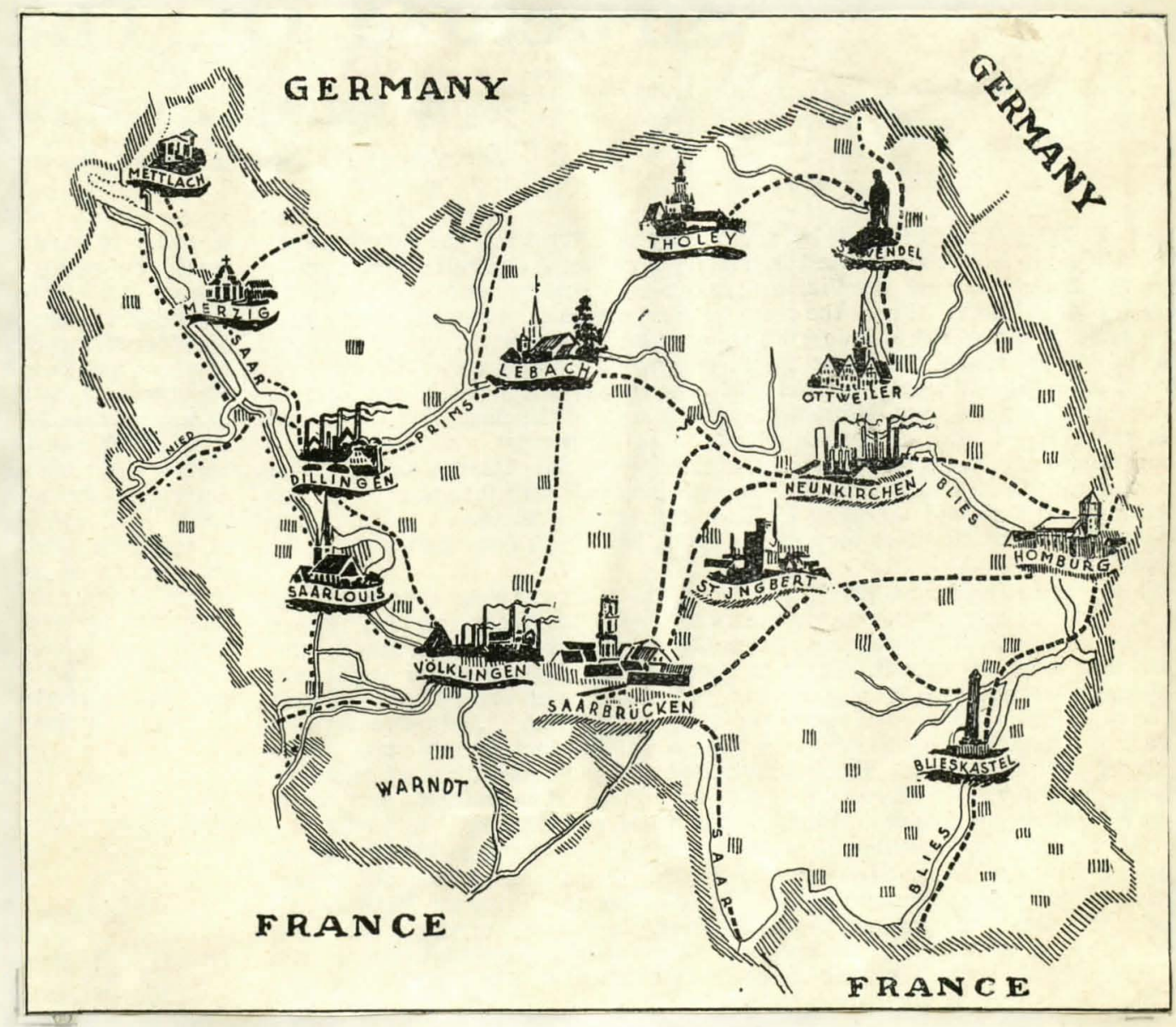


ninoteon of whioh were in operation in 1933 , 28

At Burbech tho principal conoern is called "Arbed," a Luxemburg company employing 8,000 workmen. Before the war the production of the blast furnaces at Burbach was 400,000 tone, wh11e In 2928 it amounted to 550,000 tons. With the dismantling of three furnaces and the modernization of the other fivo belongIng to this oompany, the production capacity will remein at about the 1928 elgare, but costa w121 be considerably reduoed. Acoessory equipmont at Burbech bas alwo beon improved. The rem ouperat1te coke ovens, numbering threombundred alxty, with a monthly capacity of 56,000 tons, wore inoreased by forty during 1931. $81 \times$ thousand tons of anmonlum alphate, 8,000 tons of benzo1, and 25,000 tons of ter are produced annunily as byproducts when the plant 1 operating at oapactis. 23

AlI cervices connected with the worke have been reorgan1zed. All of the blast-furnace gas is now ut1lized whother in the proheaters, to drive the blowlag engines or otherwise. The ooke-oren gas is wold to a publio ut121ty. Folling mille and waro-houses have been rearranged so as to poralt a continuity of sorr10e, wh1ch 1s accomplished almost entirely by eleotrie traotion. Two-high-preseure elootrio generators were lnatalled in 1928 and a third added in 1931. The plant has been oomplotely modernized. 24

The prinslyiz 2 teel worke at Neunk1rohen is that of the 28 Butts, Thos.. "The Frenoh Iron \& Steel Industry \& Trade," Chap. "The saar," Trade Inforester Bulletin. 23 Ibid.. p. 59 . No. $800,(1932)$, p. 58 . Lbid.. p. 59. 
"Nounkircher Bloenwerk" tormally stuam Eros., which exploya about 6,000. As at Burbech, the blast turnaces have been modernized, the eapaeity of the blowling machines increased, autometic chargers installed and pulverizers orected. Through these improvewanta the pig-1ron capacity of this plant w112 be 50,000 tons monthly, the inorease in tho production of plg iron raking additional coke ovena necesary. Twenty wero put into gervice in 2928 and another battery of twenty in Fobrusry, 1930, thus asouring. With those previousiy in operation, a monthly output of 60,000 tons of coke. Wuah attention 18 given to the recovery of the by-produots of coke manufactured at Nounk1rchen, and Installation have been made for the distillation of tar. Through the concentration and comordination of labor at this plant the number of employees has been reduoed while cepaolty has been Increased. 85

At Halberg tha old-typo blast furnaces have been rotalned, Innovations being 21 mited to the erection of one now furnace. Thls additional unit necessitated the installation of a now and larger coul waber and the construction of another battex of ooke ovens. A ptpe and fittings toundry and a two-hundred-ton capecity coment m111 ware acded in 1930 , $^{26}$

The D12119on Company employs between 6,000 and 6,500 mon. Th1s company has made 1 ts polloy to manufacture a product whioh would tiad a ready markot. Provious to and during the war it specialized in armor plates. wh the produotion of bars as a 25Ibig: p. 59. 
secondary teature. When a change in polley beoame neceseary, the manegement decided upon the production of galvanized shoete and plates, paying particular attention to boller plate. 87

The prinolpel concern at Volklingen 18 Roeohling, employIng about 7,000 workers. In the effort to adjust 1 tself to postvar conditions the company made a complote ronovation of 1 to plant. The ooke oren plant was transformed, not to produce more but rather botter ooke, the cinder content, it 18 claimed, beling reduced from twelve to elght per cent.

Here as at the other plants in the Baar, Increasing attention 18 pald to the recovery of blast-furnace and coke-oven by-products, while now uses are belng sought for the surnace residues. One development has been the erection of a cement 111, and promielng experimente have beon made in making alag paring blooks. Excess gas production 10 sold to public utili108. The eleotrio plant of the works, formerly operated by ooal, 16 now gas operated. 28

In 2913 there were about 17 coking plante in the dietriot, a large number of which wore by-product plants. These coking plants included 2,240 ovens. Ten of these belonged to the Prussian Doternment, one to a French Company, and tho others to German companies.

Had the saar coal not boen in c20se competition ith the better fuel from Wostphalla, the fleld would undoubtediy have been more extensively developed. In this competitive trade 28.pogd:: p. 60. 
the sanr ooal finds 1 to best uwe for steam, gaa, and domestie purposes.

In 1913 twenty-nine blast furnaoes baving a total da1ly oapecity of about 4,370 tons were operated in the saar distriot. In the same jear nine steel plants were operated, and these conamed not ony practically all the plo 1 ron produced in the dietrict but also some 500,000 tone laported from French Lorraino. The steel plants wore equipped with 21 Bessemer Converters of an average capacity of 21 ton and 32 sartin furmaces with an arerage capacity of 21 tone. There wore also $1 \times$ eleotrlo furnaces, at least seven rolling m112s, tour foundaries, 20 puddilng surnaces, one tube $=121$, and one armormplate plant in the distriot. These furnaces and plants produced 2,375,000 tons of p18 1ron and $8,060,000$ tom of raw ateol. No accuratio statietios regardIng the output of sinished and semi-finished products are evailable, but these producte in 2923 probably agsregated about $1,000,000$ tons. 89 since the war the production of p1g 1 ron has steadily inoreased ( to 1,918,000 tons in 1930), although steel production deorosed elightly from $2,080,000$ tons in 1913 to $2,936,000$ tons In 1930, dropping to $2,515,000$ tone in 1932 .

statistios of the production of the saar in recent years contrasted with 1913 follow. 30

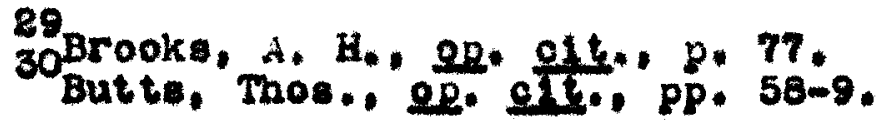


Coal. Iron, and steel Produotion in the Saar, Pramar and $1988-1932$ (In thousende of metrig tons)

\begin{tabular}{|c|c|c|c|c|c|}
\hline Products & 2918 & 1928 & 2929 & 2930 & 2932 \\
\hline Coal & 13,216 & 23,107 & 13,579 & 23,236 & 21,364 \\
\hline P1B Iron total ${ }^{2}$ & 1,371 & 2,205 & 2,200 & 1,936 & 2,515 \\
\hline Basto Bessemer & 1,883 & 1.728 & 2,898 & 2,692 & 1,351 \\
\hline Foundry $\mathrm{P} 1 \mathrm{~g}$ & 148 & 209 & 207 & 223 & 264 \\
\hline Faw ateel, total & 8,080 & 2,072 & 2.808 & 2,936 & 1,538 \\
\hline \multicolumn{6}{|l|}{ Ingots-- } \\
\hline Bastc Bessemer & 1,719 & 1,561 & 2,648 & 1.456 & 1,116 \\
\hline Open hearth & 356 & 498 & 544 & 456 & 407 \\
\hline - lootric Castings & 5 & 19 & 28 & 24 & 25 \\
\hline Sent-finished products & 256 & 174 & 257 & 168 & 135 \\
\hline \multirow{2}{*}{\multicolumn{6}{|c|}{$\begin{array}{l}\text { Ionly principal grades shown } \\
\text { Production of Prinoipal Finishod Products, Pre-war and 1928-1031 } \\
\text { (In thoueande of metrio tons) }\end{array}$}} \\
\hline & & & & & \\
\hline Products & 1913 & 2928 & 2989 & 1930 & 2932 \\
\hline $\begin{array}{l}\text { Raile, Froge, F18h- } \\
\text { plates, Switchos }\end{array}$ & 332 & 222 & 230 & 805 & 152 \\
\hline Beame & 303 & 283 & 258 & 198 & 247 \\
\hline Wire rode & 126 & 169 & 257 & 245 & 183 \\
\hline Sheets & 38 & 128 & 280 & 99 & 76 \\
\hline P1 pe & 76 & 86 & 84 & 53 & 48 \\
\hline Plates, thin & 93 & 94 & 97 & 95 & 93 \\
\hline Plates, heary & 56 & 89 & 262 & 265 & 208 \\
\hline Merohant Shapes & 482 & 183 & 497 & 447 & 354 \\
\hline Total & 1,494 & 2,537 & 1,598 & 2,407 & 2,106 \\
\hline
\end{tabular}

${ }^{31}$ Ibid., p. 59 . 
It 1s of Iundenontal Importanoe in the study of Gormany's position in relation to her nolghbore to look at the geograph10al distribition of hor hoary industries, hor agricultural population, and her conters of ooal produotion. If France elaimo that hor industries, her oanals, and hor large olt10s 210 dangerously elose to the Gorman Irontier, so also may Germany polnt to a olmilar conoentration, both oast and wests silesia no less than tho saer and the Ruhr are dangerouely nowr an International boundary. 32 Frontsers in murope galned new oconomie algnifloance. The fhine region to of partioular interest because the new boundary botween france and Germany divides Lorraine iron from Ruhr ooal. Beforo 2929 thoy wore undted by a highly efflolont raliway syoten that largely canoelzed the $250 \mathrm{mLles}$ of distance that lay between. The Muhr basin has tho largest reserves of oos and the hlghest lerel of production in al1 surope and ite coking ooal 1o without rival.

About 76 per oont of Lorraine coed requiremonts wore supplied from the Ruhr and Rhinoland and Lorralno sent to the 2atter about 28 por oent of 1ts ore. Nearly the whole export of Iron and steel from Germany. Franoe and Belgium originated in the Rubr-Lorraine syoten. These two reglone became united by oapltal combinatione and formed the greateat Inchatrial oenter in the world.

It 18 arguable that the oloser the union between industrial Franee and Germany the 20os denger there is of future war. Franoe 38 Bownan, Isaiah, The NeI World, (2928), p. 261. 
holding the Iron and Germany the ooking coal is different from Germany holding both as in 2914.

The most important angle industrial region is that of the Ruhr. Its western and is marked by a groat transportation portal (fubrort and Dulsburg) through whioh are sont coal and coke and iron in rarious form, and where grain, wood, and irop are reoel red. 33

The reault of the dirision of the industry along present natlonal boundaries leavea Franoe nearly all the 1ron ore, but inourficient coking coal. Germany has nost of the coking coal and no 1ron ore. Eoonomic Int Zuence of the Francomoerman coal, Iron and toel unit can hardiy bo over-oatimatod. Nearly all remalning Industrial aotivity of Western Burope 18 dependent upon it in one way or another for 1 to driving power, raw mater1als, sent-tiniehed and tinlehed 1 ron and steel produote. The remalning ateel capacity of Europe ts only one third as large and wettered in many units. 34

The Iron and steel Induetries of the fahr form the core of alngle eoonomic unit whioh overiage into France, Belelum and Luxembarg. The bulk of the ple iron and steol production is In the kahr territory, near the coal; the remalning production In Bolgium, Franoe, and Laxemburg is srom abordinate and tributary units. In addition to blast furnaces and steol m1128, there are many plants which put the steol and Iron into fin${ }^{33}$ midn... p. 262 . Tote. 
lohod and somi-finiehed forme; theee, 11kew 10e, are centered In the Ruhr. 35

The economie Influence of the Franoomderman coal, Iron and steel unit can hardly be over-eotimated, for nearly all of the romalning industrial activity of western burope is dependent upon 1t in one way or another for 1te driving power and for 1 ta raw, semi-ilnished, and Sinished Iron and steel products, The remaining teol oapacity of Burope is only a third as large and 18 soattered in many 8 mall und to. 36

The preponderant position of the Franco-cerman unit 18 of comparatively recent origla. The real use of the Lorraine-BrieyLuxomburg iron orea began oniy with the invention of certain wotallurgloal processes in 2880 and the production has roached large rolume oniy in the last two dooades. 37 In the ear2y porlode of emall production of Iron and steel many scattered mall unlts oould supply 2004 needs, but in It now glgantio proportions the ophere of influence of the Franoo-German industry cannot be so divided. Tuture sottlemente of auropean boundary questione have this new oondition to deal with. 38

The politioal control of th1s great induetrial weapon means politioal supromacy both in war and peace. The blatory of the Inoreasing bitter truggle betwoen France and germany for control of the induetry Indieated a groming recognition of this

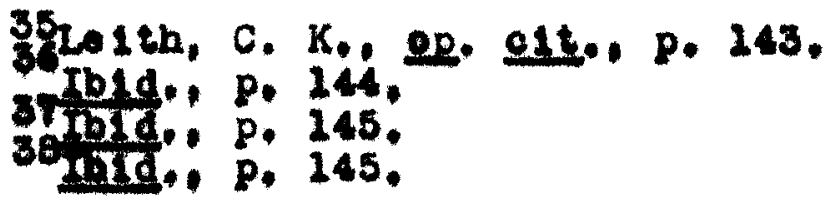


saot.

The Lorraine ore deponite are by far the most raluable in Europe, beoause

(1) they contain the largest reserves occurring in ono Rleld:

(2) they are readily aocessible and within easy communlestion of large coal rlolde;

(3) they are of auitable oomposition for the basio procese; and

(4) they are mined at oomparatively low cost.

The total reserves of Iron ore in the Lorraine field are estimated to be 5,000,000,000 tons. This estimate, becalued of the comparstive regularity of the deposits, 10 probably nore near $2 y$ accurate than those wade for most iron-ore dietriote. The distribution of the Iron lands and reserres by countries and distriets 10 as rollowe: 39

Area and ore reserves of Lorratne 1 ron f2eld, 2923.

\begin{tabular}{cc}
\hline area & Ironore reeervos \\
(heotares) & Tons \\
\hline
\end{tabular}

$\begin{array}{lrrr}\text { Fronch Lorraine } & 67,610 & 3,000,000,000 & 58,80 \\ \text { Lorralne Annexee } & 35,860 & 2,830,000,000 & 35,90 \\ \text { Luxemburg } & 3,670 & 270,000,000 & 5.29 \\ \text { BoLg1un } & 400 & 585,000 & .02\end{array}$

A Valuable charaoteristio of the Lorraine Iron deposits is thet they contain both calcaroous and 121000us ores, making it pos${ }^{39}$ Brooks, A. H., op. alt., p. 18. 
alble to obtaln the proper mixture cor blast furnaces. 40

The regularity of the Lorraine ores, which oocur in beds, and other favorable conditions tend toward 20: minlng costs. In 2913 the cost of mining was erom 3 to 4 srence ton. Thls 1. Lower than cost of mining in most other furopean iron fields. W1 th the restoration of the Lorraine Annexee to Prance the has more or lose of a monoply of the avallable iron ores of cont1nontal Europe.

There are $\$ 1 \times$ coal 1102 de w1thin 250 k1lometers of the Lorraine iron districte whioh have a total knom reserve of about $86,000,000,000$ tons of coal, of whtoh at least 10 per cent to oultable for coking. Under present tallurgio practice it w111 require total of about $2,500,000,000$ tons of coking coal to onolt the entire iron reserves of Lorraine. Therefore, there 18 moh more coking ooal in these flelds than is noeded for ald the known Lorraine ores. About 74 por cent of this coking coal 18 In the Woetphsilian lield of Germany. 48 me Westphallan coal I102d of Germany is in the 20wer Rhine Basin, oblefly oast of the river. Being olose to tidewater, it is favorably situated for export trade. What is more important to thle discuselon, it 1. conneoted by railway as well as by rivere and oanals with the centere of 1ron and eteel manufacturing of Lorraine and of Bel81uan. This fleld contalns 56 per oent of Germany's promar b1tualnous opal reserves. Without the saar ooal t1eld, the Fest-

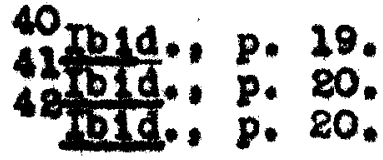


phallan $1102 d$ contelns about 70 per cent of tho coal roserves of the German ropubl10.43 The Wostphallan coking coel 13 anons the bost in Burope. This faot, coupled with 1ts geographic 20oation w th roterened to the Lorraine tron ore on one hand and to t1dewater on the othor, has made Westphalle not only the greatest coal producing center of Cermany, but also the scene of the most extenesve manurecture of 1 ron and eteel. 44 In 2913 some 4,500,000 tons of Lorralime iron ore were smelted in the Weatphalian distriat. In addition about $2,240,000$ tons of pig Iron made Irom Lorraine ore were refined in westphalla.

The Iron mines of Lorraine Aanexee in 1913 produced 75 per cent of the 1ron-ore output of the German ampire, and their reeerves then constituted 47 per cent of cermany's total. In oapaelty the Lorraine furacoes and steel plants are second only to those of Westphalie. The Iron ores of Lorralne Annexeo can be shlpped by water grade down the Moselle valley to the Fhine and to the Hestghelian coal Flelde, and they are in easy communication with the saar ooel fleld. It is this geographle position thet gave them under the pre-war conditions an oven far greater Impartance than the above stated percentages of reserves would seen to indioate. 45

The efflotenoy of sear coul in blast furnace practice 18 about 67 per cent of that of the Wostphalian doul. The saar coke oan be effectively used in blast furnaces only by mixing

$$
\begin{aligned}
& \text { 437bld.. p. } 24 . \\
& 4 \text { fold.: p. } 24 . \\
& \text { ibte., PP. 80-1. }
\end{aligned}
$$


1t with at least 80 por oent of Westphallan or equaldy good ooke. The sear tield has extenalve undeve loped reserves." 46

The boundartes of the saar ooal $\$ 1020$ are $f a 1 r 2 y$ well known on the north. south and east. On the west the cosl beds plunge under a heary cover of younger atrata and the limits will be determined by the depth of profitable mining. The coal formation has been treoed weetward to the old boundary between French Lorraine and Lorraine Annexee, but it is here undevelopod. It 1s also known to oocur in Mrenoh Lorraine north and northeast of Nanoy. where coal beds have been found by boring at depthe of 800 to 2,500 moters. Woat of the developed field $210 \mathrm{~s}$ in the saar distrlet of the Fheinland, but thore 1s some of $1 \mathrm{t}$ in the Bavarian Palatinate, and In Lorralne Annoxee there is a very large area in whioh wore or 10 so col bas been found by boring. It is imposeible, therefore, to givo exact ligures on elther the area or the tomage of the 5102d. The following table sumarizes the avaliable intormation on the area of the ent1re Iseld. Of the output in 2923,78 per cont was taken from the aines in the Saar diatriot proper (Fho inland). 4 Ares of tho Sanc coel Fleld. in savare kilometerse Area of known Area of poselbze coal 2ands. coal lands.

Fholaland (sear district) $\ldots . ., 200,000$

Bavarlan Palatinate .......... 5,000 40.000

Lorrain

Annexee............30,000 $\frac{60,000}{135,000}$
47ibid.: p. 25. 
The best information avaliable indieates that the saar cosl I101d contains from 27 to 32 workable coal bode, aggregatIng 38 to 43 moter in thioknese. Hany of the coal beds are separated Into a number of benoho $B$ by soame of bono and shale. 48

The coal beds of the saar fleld are commonly tilted at rather low angles but are broken by faults. The altitude of the beds favore ohesper minlng than can be done in tho ooal rlelds of Testphal1a, Northern France or Belgium. As the coal beds are for the most part under a thick oover of baren atrata (75 to 1,000 meters), the mining 10 done by skafts. So far as known the depeet ahats ere 800 moters deep, but the average depth of mining is probably less than half of this. 48

In 1913 fourteen Dovernment mines produeing $13,000,000$ tons of poal and seren private mines produelne 4,000,000 tous were operated in the sear region. About 70,000 men were mployed in the coel ines. The size of the minins operations in the saar fleld 1s Indieated by the annual cosl output per mine, whioh is about 800,000 tons 50

The totaj coal reaerves of the saer Basin to depth of 2,000 metere have been estinated at $16,548,500,000$ tons, or th1s total 9,769,000,000 tons occur in beds lying within 1,200 weters of the surface. The total coking cosl to a cepth of 2,000 matere is estimated at $0,299,000,000$ tons, of whlch $4,086,000,000$ tone 110 within 2,800 moters of the surface, Only about

$$
\begin{aligned}
& \text { 467b1d., P. } 73 . \\
& 49+610 .: \text { p. } 75 \\
& \text { Ibld. P. } 76 .
\end{aligned}
$$


$4,500,000,000$ to $5,000,000,000$ tons of the total coal reserre 110 in the developed part of the rield. The rest of the coal (about 75 per cent) Is in such areas or at such a depth that it is known oply by drizling. 52

The ooking coal of the saar fleld is of an inferior grade to that of the Fronoh, Belglan, and Westphalian I1elds, with which it comes into compotition. It most direct conpetitor 1. the Westphallan coal, which yielda about 78 per cont of coke, as compared to about 50 per cent for the Saar coal. Bven in the saar distriot 1 tself, as is shown below, wat Westphalian coe1, as woll as wome coke, 18 used, Horeover, the Saar ooke 1. not otrong enough for blast-furmace use. The best coking praotioe In the saar $\mathrm{rleld}$ prorides for an admixture of 80 per cont of mostphalian ooal in the ooke orens. For surnace charges 250 tons of Fostphnilan coke is oons Idered the equal of 180 sons of Saar coke. Rodueins these Inotors indicates that the ralue of tho Saar coking coal for furnace use 1862 per sont of the value of the Festphalian ooal. In blast-furnace praotioe it 1. customary when conditione permit to make the okarge of equal quant1t10s of saar and Westphal1an ooke. 58

Before the war the coal flelds $2 y 1$ ing in the sear distriet (Fholiniand), was owner and oxplosted by the Royal Pruselan Covernment. The Bavarlan Government also owned coal land and operated two mines in the Palatinate part of the r1eld. In add1tion to the Government-owned land Iow concessions had been

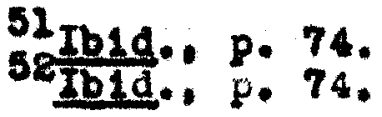


made in both the Saar and the Palatinate to private oorporations. The following table sives the approximete areas of the coal lands in Government ownership and in private ownership. 53

Cosl land in Government and private ownershlp in Saer $1102 d, 1913$ in heotares

\begin{tabular}{lrccc}
\hline & Fheinland & $\begin{array}{c}\text { Bavarian } \\
\text { Palatinate }\end{array}$ & $\begin{array}{c}\text { Lorraine An- } \\
\text { nexee }\end{array}$ & Total \\
\hline \multirow{2}{*}{ Government } & 120,000 & 4,370 & $\ldots \ldots \ldots$ & 114,370 \\
Frivate & 112 & 630 & 48,570 & 43,312 \\
\cline { 2 - 6 } & 110,118 & 5,000 & 42,570 & 157,682
\end{tabular}

The dotells in regard to the German ownorship of coal mines and lands and ooking plents are sumberized in the following tablo. 54

Ifetimated value of derman holdings in the Saar district, 1913 in eranes.

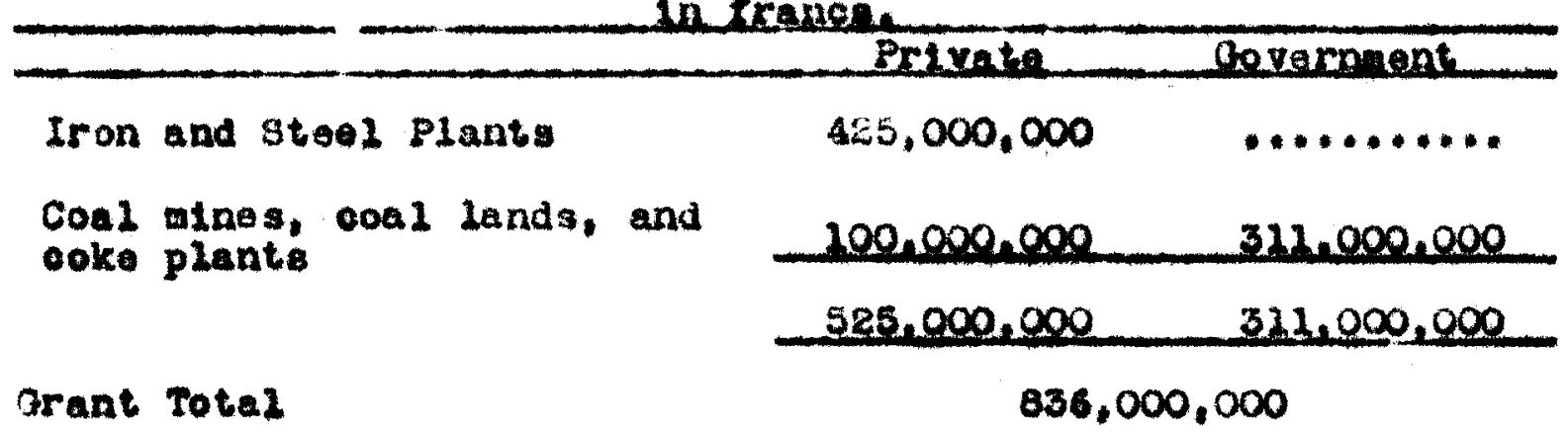

The saar Territory, and as it 18 , Involves one of the stirring, even noute questions of tho civilized world today. In a messure, something appreciable in the future of Europe-Europe's peaee, security, goodw112 ard roconc1liation is bound up with the pate of this nugget of induetrialisa, this "dimin58 Ib1d., p. 74 . 
ut17e mass of preolous wetel." It is one of those interse matters on whioh a oriale, in wose sense, depends; in which overy word and every action matters; in which almost avery gesture is fraught with possible oonsoquences of tar reachlng good or 111. The Treaty of Versallles added the sinal touch in the prom coss of making coel a lirst rate politioal lasue. It was perhepe only natural that the I1rst ereat coonomic war hould be followed by a treaty in whioh econonte consequenees were prorided for on a ceale nover dreamed of before. Feparations in the form of speclsted deliverlos of oond and ooke to rranoe, Belgitu and Itely. woro a $2081 c a l$ provision, slrot because of planned Injury done by German armles to Tronoh mines, and sooond bocause coal represented the one great exportable commodity which the allied natione readily could take erom Gormany without undesirable effeots on their own laduetries. $\$ 5$

Provision for "sanetione" or "produotive guarantees" in the orent of the pon-fulf 121 ment of treaty obl16ations not unnaturally opened the way for the poselble oecupation of tho Ruhr distriot. partiy because it was a convenient and desirable Industriel center to se1ze, and partiy because the output of the Wostphalian coal 8102 das vital not only to the reparations ooul dellveries but also to the whole ecoponte organization of Ladustrial dermany. 56

The tranefer of coal flelds by the treaty, as in the cases of silesia, Tesohen, and the Saer Basin mas magalfiec tho imo 85reaty of Vercillee, Part VIII, Annex V, Par. 1-10. 
portance of the politioal oontrol of these resources. Under formor conditiong a oertain degree of balanoe between the ood output and the dependent industries had been esteblished as a result of long processes of economlo adjuetment. That balance of interrelations hes been disturbed by the shift of boundaries.

The oeteneible reason for the eedzure of the fuhr distriet was to force Germany to pay her reparations. This invasion aroueed an outburat of rage, revolt and batrod anone the ferm man Nationaliots. The Germans folt, however, that it was not beyond doubt that France's roal intentions wore to selze the woalth of the Ruhr, in order to get monopoly of the coal, just ane had gained the monopoly of the iron by anaexing the Lorraine mining beein. 8 ?

The real auses of the oecupation of the Fiabr are rooted in the slustion oreated by the Troaty of Versallies. It w111 be remembered thet during the Peace Conforence two fundamental problems demanded oolution: The problem of rrenoh and allied seourity, coonomie and military, and tho problem of repairing the danages aused by the wer, 58

As far as the Fuhr-Lorraine Industrial problen is copcerned, the oequpation had this negative ralue: It has demonatratod the diffeudty, not to say tho imposelbility of solvIng a problem which 1s essentlally eopomis by the application of polltioal and will tary toroe. 69

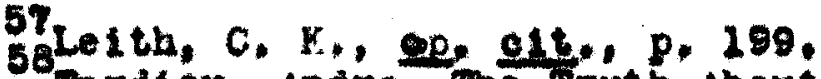
59 Tardiou, Ancire, The Truth About The Treaty, (1921), p.261. Langsam, $N, C .$, op. Git.. P. 164. 
60

It woula be abourd to Lgnore the poseible future consequences of Interfering w1th Buropean ooud supplios. Burope must be thought of as a vastly complex industrial organization In vehich coal is the indispansible ractor, In the cortast for control of thl cheap and coarenlent sourse of wochantcal onergy there 18 roos for mah trouble and futurs conflict.

It must be admitted that the question of cosl sugplies hae cened to be a purely eoonomio mattor of $20 c a l$ interest. The ooal queation as it is doveloping in surope is an 2nternational lasue of major importanoe; and as Europe stands in relationship to the reat of the worla today there se tow nations whloh are not concerned in the anewer. 


$$
\begin{gathered}
\text { CHAPTEA IV } \\
\text { THE OCCUPATION(2980-2935) }
\end{gathered}
$$




\section{THR OCCUPATION (1980-1935)}

On February 13, 1920, the Counc1l drew up for the fovernIng Commisetion inotruotions which ombody a statement of principles and rules of procedure based on the Treaty provisions. It laid down as Iundamental principle that the Commiesion's sole Interest should be the welfare of the Inhabitants of the Territory and that the Commiseion wes responsible to the Laague for the execution of 1 to mandate. It was instruoted to keep the League regularly informed of all questions of intereat to 16.1 The Commision acoordingly submitted offictel quarterly reporte, which were olroulated to all Members of the League and printed in the Offletal Journal of the League. It sent epooial reports on matters of particular interest. The Commission wae required by the Versaliles Treaty to secure the views of elected representatives of tine inhabitants bofore any change in the laws could be wade, or any new tax Imposed. Unt11 1982, It considered for this purpose the hunielpal and Distriot Couno118. 8

Four of the sive members of the Governini Comienton were appointed at thls session of the Couno1l, to hold office for a perlod of one year erom date. They were M. Rault, State Coun-

${ }^{2}$ zr10 Drummond, Ten Teare of World $\frac{\text { Comoperation, (League }}{\text { Of Nationa) }}$ Ibld.. p. 382 . 
c1110r of France; Alfred Von Boch, Landrath of Saer2ouls; Major Lambert of Belgium; and Count de Holtke Kultfoldt, a Daniah netional. The effeh member was to be R. D. Haugh, of Canada, although his name was not announced at the time as h1s acooptance had not been recelved.

The four meabers of the Coverning Commission were prepared to aseume office immediately and, in vien of the desirability of relleving the population of the sear of the m111tary réglme to whioh it had been subjeoted since the armistice, they deolded to proceed wi thout delay."

The Governing Comilesion arrived at Saarbrioken on February 21. Even before 1ts official entry into the olty it held several metings in Councli, at whloh it examined and decidea some Important questions. The first task of the Gorerning Commisalon was to deolde on 1ts own intermal organization.

A tentative dietribution of duties was therefore one of the P1rst matters to be deolded. The administrative work was distributed among the members, each having obarge of several departments. The obatrman, M. Bault, essumed the control of the departmente of Agrieul ture, Publie Health and Soclal Inourance; Major Lambert, the departmente of Publie Worke, Ha12ways, and the Postal and Tolegraph services; Count do Moltke-Huitfeldt, the departmente of Eduoation, Re11gion and Just1ce; Mr. Neugh, the departments of Finance and Food Control."

The oholce of the seat of government was another task, and ${ }^{3}$ League of Nations ofricial Journal No. Z, (2980), p. 49.

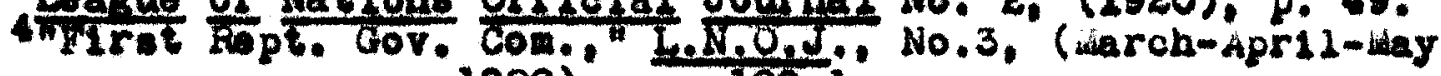
5. 2980): PP. 100-1:

"gecond Rept. Cov. Com.," ibld." (June 1920), p. 192. 
this constituted a probles at the outset. Both Saarbrïcken and Saarlouls desired to be ehosen. A petition from inhabitants of Saarlouls had been sent to the Seoretary General of the Loague asking that the saarlouls be designated, and the hayor of the o1ty was aotive in behalf of 1ts selection. The Commisalon deolded, however, that, "In splte of the historical claims of saar10u1s," the more populous Indastrial center--Saarbrucken--should be chosen. Saarlouis was consoled, however by the dectsion of the Commiesion to establiah the C1712 and Criminal Court of Appeal there. 6 Thooe proliminary moasures were merely an introduotion to the atupendous takk the now government had to face. It Involved the oreation of an ontirely independent administretion which was to provide for all the activities of a modern induatrial state.

On Fobruary 25, the day before the Commisston asoumed power. 1t posted and had printed in tho nowepapors of the Baar a proolamation to the inhabltant designed, doubtless, not only to Inform then of 1ts general policles but also to antiolpate opposition to its authority."

The proelamation went on to assure the Inhabitants that the Conmission would enforee respect for thelr rights and well-belng, that 1t would endeavor to restore the prosperity of the Territory, that it would pay partieular attention to the develogment of Industry and to the 1mprovenent of the conditions of the workers, and that in the exerolse of 1 ts authority and in 1 ts administra-

6"mrst Rept, Oov. Cos." op. O1t.. (March 25, 1920), p. 102. Ibe.. P. 107 . 
t1on, It would be "Inapired by the prineiples which directed the establishment of the Loague of Nations. ${ }^{8}$

The rogime of the sear had romalned practically unchanged since the Armitice. The ooming into force of the Peace Treaty bad not aoftened it in any way; notwithotandine the ability and taot of deneral Wirbel, the Suprene idministratur of the Saar, to whom the Prosident of the Commiesion made a point of paying - public tribues on February 26, the military occupation and the dlotatorial powers implied by 1 t welghed hoarily on the popvlat1on. 81noe Norember 12, 1918, the Saar had been 11ving under a provietonal réglane without any legal basis; none of the numerous and serlous questions arising since that date had been settled. The Comiselon, instead of devoting all its strength and time to organiaing ite government and carrying into effect the Treaty of Vermallioe wes consequentiy obliged, immediately after Ito Intel2ation, to deal il th urgent and complicated problems. 9

From the first, the coonomic position of the Saar seemed to the Commisation to be oritical. The minas, which are the great wealth of the Territory, had been given to France for tho purposes of oredit on keparation, the country thus belas deprived of 1ts principal resource. Loreover, the Treaty stipulates that the Sasr Basin shall bo inoluded in the Fronch customs róg1me. The taking over the mines and the custome by Fronch agente, consequent upon the coming 1nto torce of tho Troaty. Ipre.: p. 108 . 
oould not be arranged without distarbing the normal couree of business and damaging mapy interests. Further, the supplies of the oountry, hither to assured by Cermany, soemed to be more and more endangered. 10 The sltuation was rendered still more difficult by the proxinity of the French frontier, which emptasized the differenoe, at the rate of oxohange then existing between the irane and wark. Goods bought in France (In trancs) reached extromely high IIgures (In marks) whon they were sold in the Saar. Wages had to be continually lnoreased. Persons liring on flxed Inoome and those on the rotired 11 st were expocially afteoted by the depreolation of the mark. The oris1s became st111 more aoute when the Irenoh state mines, aralling thomselves of a right conterred on them by the Treaty, pald tholr workmen, and oompolled thom to make tholr purchases and ales, In Irancs. The absence of all polltioel 21fe, the economic difficulties, and the constraint of a prolonged milltary regime, had undeniably provoked unrest among the 1nhebitants. 11 The1r disoontent had been aggravated and exploited by those, who, within the saar as woll as elsewhero, had not accepted the Treaty of Versallles and wore proparing elther to tear it up or to ovade 1ts stipulations. The Commesion had proofs that the population had been worked upon by agents whose objects were altogether removed from the Interests and welfare of the inhabitants of the Saar. When the Commision entered on 1ts duties, these agents attempted to profle by the oocasion to promote disorder in the country; certaln of them delivered inf lammatory peeohes at public meotings. 10.mid.: p. 102. 
The agltetion colncided with the attempt made at Berlin to estab110h a military diotatorahlp. It was inspired by tho ame 1doas, and the same hopes, and doubtlese, by the same men. 22

Confronted with this eltuation, the Governing Comiseion refused to take any serere measures; no publ10 meting was prom hiblted, no nowspapor was suspended, and not a single Inuividual was expelled. The president simply called together the leaders of the political parties and explained to them the lino of conduct that the Governing Commisaton bad chosen, stating that 1t was resolyed to malntaln order in the Territory. The Commission had the satisfaction of noting that its advice was ro- peoted. Contrary to the otatements of certain soreign nowepapors, there bad been no disturbance within the ontire Torritory of the sear. Oniy one manifestation, on the part of a few hundred parsone and lasting not over an hour, took place in the atreets of saarbrücken. It was without inoident, save for the olnging of petriotic songs, and a patrol of fifteon men was surflolent to disperse 1t. The fen strikes that took place all origineted in the demande of workmen for higher wages. They were of ohort duration and were settled without the least difreulty. 13

The foregoing genoral remarks on the politioal and economic altuation in the Territory of the Sear were necessery in order to explain the diffioulties Ith whioh the Commeston had to deal and the precautions that it had to take in organizing a new régime.

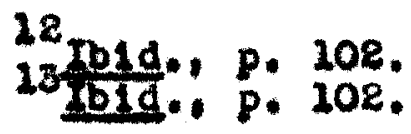


Its Irst conoern was to substitute a civil administration for the miltary adminiotration. To this end it reteined the groater number of the officials appointed by the Prussian and Bavarian Governments. As to cholce of new wen it wae vory difficult to Find Immediately among the native inhabitants of the Saar, a country almost exclusively industrial, mon ouffiolently trained for publ10 of 1100.14

The allitary odministration proper completely disaypeared; 1ts representetive in the Diatriote (Krelee) had been relieved of the ir offlces. The Contiston endeavored to organize lts services in the shortest poselbie time. Immodiately after 1 to arrival in saarbrucken it established a Secretarlat-General, whose prinolpal duties were to prepare tho meotings of tho commission, to draft tho minutee and to keep the Archives, and fimily, under the direction of the prosident, to malntain relations with the League of Nations. It has organized a Do partment of Publie safoty, without which it would not have been possible to dispene with the Fronch Military pol10e, and a serrice for the Inepection of Mines. Mithout the latter it would not have been able to guarante to France the free explostation of the mines whioh was conferred on her by the Troaty. 15

There is no question but that the Coverning Comalasion of 2980 was otrongly pro-French In 2ts mako-up. H, Rault was a Frenoh Counse1lier d'atel. Ho spoke no German, a language of whioh Hr. Waugh also was 1 gnorant. Major Lambert was a jolelan.

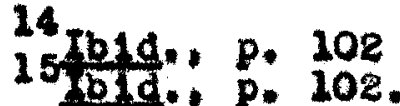


Count Von Moltkomfulteld, although a Deno by b1rth, was a realdent of Paria. For thirty-tive years his ether had been the Denish Minister to France. 16 As the decisions of tive Coverning Commission were to be mado by a jortty vote, the preponderance of the Frenoh polnt of view ma assured. 17

The majority of the original members of the soverning conatasion were all known to be Fronch in their sympathios at the t1we thoy woro appointod. Indead at least two of tham were prom posed by France. When tho Saar nember, Von boch, roalgned in August, 1980, Dr. Hootor, who had recotatsonded himself to the Frenoh as early as July, 1929, when he was mayor of Saarlouls, by h18 expressione of loyalty to Erance, 28 was ohosen by the Counc12, on the recomendation of id. Caolsanos, as Von Boch's sugcessor. 29

Dr. Hector ald not at all represent the wiahes of the great majority of the Saar inhabitantis. He was ragaried as a tool in the hands of Prestdent fiault, and eventually he had to resign when he was virtualiy oonvioted of perjury in oonnection with a pro-Prenah 1oster he had writtan to Clemenoean during ino Peaoe conterenoe. 20

France therefore enjoyed from 1920 to 1923 alwost as much power in mattere pertalning to the saar as sho would have poscessed had the proteotorate demanded by her in 1919 been granted.

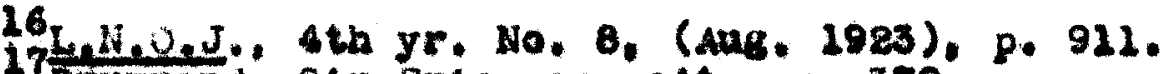

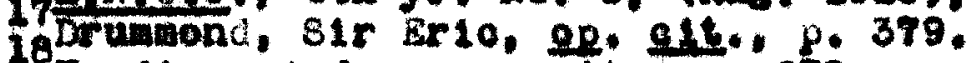

19 Tardiou, Andre, op. Qit., p. 279.

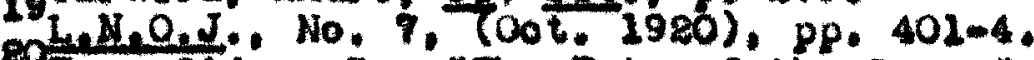

Tay. Slaney B.. "The Fate of the saar." Current Hlstory. (Jan. 1955), p. 403 . 
The moane of soouring a politioel and adminlstrative rogime in the Saar favorable to Frenoh Intereats lay in the control of a majority of the mombere of the Governing Comiseion and in haring the ohairmanthip of the Comalesion in sriendiy hands. Tho oheirwankhip, and, as ansequence, the executive power of the Comiseson, was given to the Frenoh member at the time the CounQ12 set up the Commiesion. 21

When Dr. Hetor was forced to resign hls post, he suggested a b1. subetitute $M$. Julius Land. When the question of choosing - avecesseor to Dr. Hector eame before tho Counc1d, M. Hanotaux, the Vigilant Frenoh representative, proposed the nome of H. Land and the latter wes then eleoted. $2 E$ Thus the French virtually controlled four of the five members of the Comiseion.

WI th these racts in mind there was no ocossion for gurprise at the attitude taken and the policles adopted by the Gorerning Comiseion. Furthermore 1 wae not strange that $M_{0}$ Horize, a Frenchman, was appolnted Seeretary-General of the Commission to aseist the Frenoh Prasident, that the majority of the foreign officials brought into the Torritory by the Governing Commisaion were Frenohmen, and Inally that the French representative on the Councsl of the League of Nat1on was the one who rose to a Vigorous defense of the Governing Commsaton when it was eer1ous1y attacked. 23

In acoordance w1th the Treaty of Veraallies, the Saar Ter21L,N.O.J.. No, 2, (Warch 1920), p. 46. 22L.N.0.J.: 4th yr. Book No. 6, (June 1923), p. 598 . 23 Ibld., No, 8, (1923), pp. 859-862. 
ritory was to retaln 1 te C1712 and Criminal Courte. 24 Howerer under paragraph twenty-five of the Annex, to seotion IV of the Treaty of Versallles a supreme Court was to be established in order to hear appoals agalnst declotons rendered by tho local tribunals. This was necessary to eliminate from the saar the juriediction of any tribunals constituted beyond its eroutiers. Cases which formerly went upon appeal to courte alttine at lolp218, Berlin, Muntoh, Cologne and Zwelbruoken were to be heard by the new Court. Th1s court was duly organized in June, 2920. In setting up this court the Commasion decided that the judges should be selected from countries members of the League, of Its - Levon judges two wore searlanders, two Frenoh, from Alsace and Lorralne, three were swies, one Belglan, one Hollander, one Czecho-slovak, and one Luxemburger. Professor A. Nippold of Berne was appotnted preeident of the Court. 25

The power of the Commission over the public ofticiale of the Territory was carefully provided for in the Treaty. 26 The GovernIng Comiesion Inherited from 1ts predecessors, the states of Prusala and Bavar1a about 30,000 offictals of all grades in the saar. 27 The oreation of a 01711 serviee drawn entirely from the ranks of the natives of the Sear, which was legally withln the powers of the Commission proved to be a practical impossibility

24" "Th1rd Fept. Gov. Com.," ge. Q1t.. (2982), p. 238.

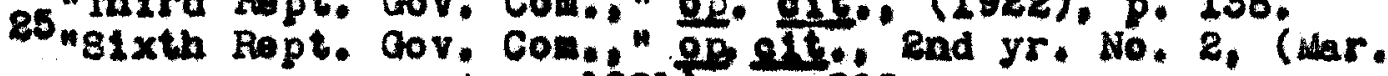
26 Apr. 1921). P. 805. eq Verealliee Treaty Part II, 800 IV, Annex Par. 19.

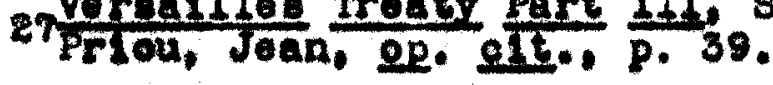


due to the lack of suffiolent number of trakned men and in viem of their reluctance to take the place of their dismased colleagues, natives of the other parts of the Reich. Considerable friction developed between the Governing Commieston and the permanent offlolals regarding the conditlons of service under which these officlals should be taken over. The matter came to a head as result of the publication of the Civil servents statute in August, 1920, which led to the strike of all state employese and aypathetic atrike of employeos in the publio service.

The strike was accompanted by the proclamstion of a "etate of slege" and the eurrender of polles powers to the officer commanding the Fronoh garrison, roquisitioned the services of the rallway omployoes, and obtalned from the French hruy of the Fhine - Tleld Rallway Company, in order to inoure uninterrupted train service through the saar. At the same time, in order to prevent the etrike erom proading to the mines and metel workers. Presm Ident Fault undertook the task of enlightening the unions, "as to the true cause of the strike." 28 all efforts on the part of the strike commiseion to induce the minors and motal-workers to make oommen cause with the offlolals proved frultiose. A number of expulalione were ordered. Public meetlaga were prohibited, ceneorahip of the prese was ectablished, and two newepapers were suspended for having published articles without the permisesion of General Briesaud-Desma1liet, Commander of the troope in the sanr. 29 The strike onded on Auguet 14 ; the of80"Confidential Report of Auguat 18, 2980 from Pres. Rault 29 wrifth to Lague," Coune12 Doounent ${ }^{A O}{ }_{2}$ (Aug. 28, 1980). 


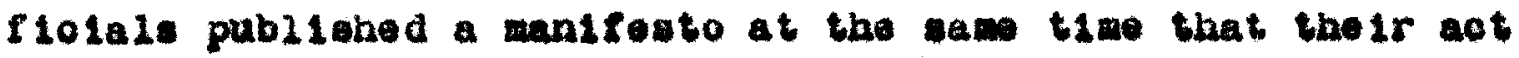
was not to be interpreted as an eoeptanes of the Goverains commiasion's position. The general twenty-tour hour otrike that took place at the last was an expreseion of sympethy for the ofr101ale on the pert of the workers of the Territory, and a a proteat against the aotion of the Governing Commiesion. The Coumisaton oongratulated 1teelt, however, on the suocess of ite resolute policy.

The anthority of the Governing Connlssion had thus been otrengthened as a reault of the orisie. If the Comminsion had not adopted suoh a Irm attltude disorders would have rosulted; the Comisalon would have lobt all prestige with tho population; and to suecees would bave beon irretrievably oompromlesd. 30 The strike, however, proved uneuoceserul and the Clvil SorTants Statute oontinued in operation. It released the Prussian and Baverian emplovees from thelr former alloglanoe to the fioloh and made oompuisory the taktng of an oath to the Goveraing Commieston. 31 The rights of elvil employees as to pension, ansor1ty. and promotions were expeguarded. After the termination of the otrike wost of the employeos were reappolnted and a nuber of sentenees imposed by the courts martial were commuted. 32 The Coverning Commiesion, reserving its provious dosialon on acoount of the high oost of $217 \mathrm{ing}$ authorleed payment to be wade to the 80

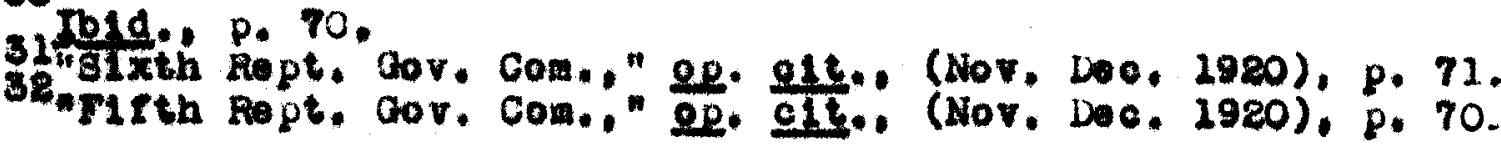


offielal workers in the publie sorvices for the days during wh1oh they were on strike.

Oae of the consequence of the eontroversy over the olvil cervante was the renignation of Berr von Booh as the Saar momber of the Comisalon. 33

The decision of tho Doveraing Comiseson to intrust the prom teotion abroad of the intereste of the Inhabitants of the saar to the French diplonatio representatives proveked considerable protest on the part of the Germans. 34 The German Government retused to rocognize this doolelon on the ground that the troaty siplidated that the "existing mationality of the imbabitante" which is German, would not be affeoted. 35 The representation of Saar Intereats abroed by Franoe and the definition of MinhabItante" by the Commiseion were two stepe tomard oreating a saar Nationality.

The Ordinanos of June 85,2981 , which defined the statue of Inhabitante of the saar Territory provoked maoh approhension In Germany. 36 It was complloated by the provision of the peace Treaty which doelared that the "exioting nationality of the inhabltants ${ }^{87}$ remained unaffected, and thls provision was reprodueed in Artiole I of the Ordinanoe of June 25. M. Falt stated In b1s report to the League of Nations that "the status of "Inhabltant of the saar Territory' oohstitutes a new kind of position

33 34pld.. p. 66. 3.tbid.. p. 67 .

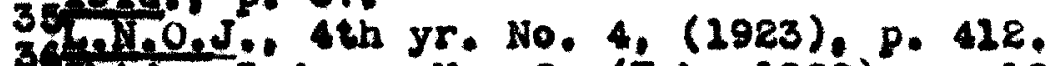
37bid. 3rd yr. No, 2 , (Fob. 2922), p. 226. 37 rreaty, Boo, IV, Annex, Par, 24. 
before the law," Article 5 of the Dooree lays down that no inhabltant of the Saar can be expelied. hay person, therefore, who can legitimately claim this qualification has froe acoess to the Territory of the Saar, oven if previously expelled. The decree was necessary to essure the equality of the riguts of the inhabitants, whether Gormans or not. 38 In virtue of this 1esislation the Governing Commission proceeded to 188 ue sear passports. The status of "inbabitant" was not 11 mited to porsons ectually born in the Territory or who lived there before wovember 11, 1918. It could be acquired by any person irrespective of natlonality and sox, who shall have had his legal residence In the territory of the saar Basin for a period of at least three years, during whleh period ho shall have been subject to direot taxation. 39 The period of three years wight be shortened to one year, lin the case of person appointed to public office or oocupying positions which required that the Territory should pe tholr main residence. The status of 1mhabltant for the latter group oould be lost by a transfer to residence outside the Territory after the explration of one year. 40

The Treaty had otipulated that the Sear was to be an "autonomous country Independent of Germany." Acoordingly, the Commission abolished the Cerman Ilag and designed new one of blaok, white and blue, for the Territory. The Imperial aeal was superseded by one incorporating the coats-or-arms of the

$$
\begin{aligned}
& { }_{38}^{38} \text { L.N.O.J., and yr. No. 8, (Nov. Dac. 1921), p. B42. } \\
& \text { 39 L.N.0.J., 3rd yr. No. 2, (Fob. 1928), fr. 126-7. } \\
& 40 \text { tbldes. } 127 \text {. }
\end{aligned}
$$


four principel sear towns. Gorman postage stamps were replaced by those more becoming to an autonomous province. They joined the Univereal Pootal Union and tho Undrereal Telographie Convention. The nev Ilag, eeal and stamps oaused no end of oppoe1tion. 41

The treaty provisions for the incorporation of the sear in the French tariff eystem and the right of the Frenoh to use the Frenoh trano instead of the German mark ${ }^{42}$ were used, so the inhabitanta selt, to break the oconomic bonds with ciermany and t10 them more closely to France. The derman Government argued that the Introduction of the franc into the public services was a riolation of the Treaty. The Governing Commiselon however presented a legal case based on the provisions of the Treaty in justifying what it had done. 43 The Governing Combisston adopted the use of the tranc in the postal and rallway aervices on iay 1. 2981, and for the payment of 1ts employees on August $1,2921.44$ On June 1, 2923, the trane was proclatmed the sole legal meane of payment in the saar Basin. 45 The saar profited by beling under the ${ }^{6} 6_{\mathrm{g}}$ ime of the frane rather than the mark--the frane havIng suffered lese from inflation. Of thoir gains the Searlanders have sald $116 t 1 e$.

Several more questlons arose to increase the aldagonism between the Governing Commission and the Stur Inhab1tants. The

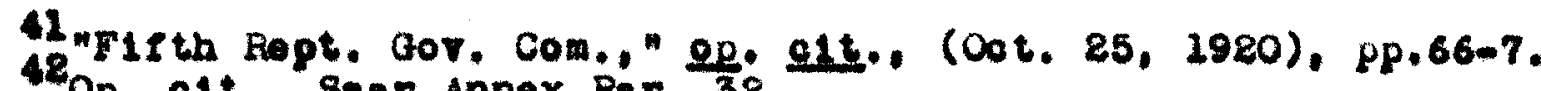
48. ple. Saar Annex Par. 38 . 43. L. O.J.: End yr. No. T. (0ot. 1920), pp. 688-9. 44mereath Rept. Gov. Com., " L.i.,0.J." and yr. Nos, 5-6,

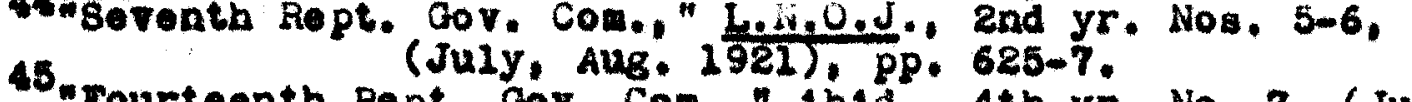
ig23). pp. $74 i-2$. 
latter wanted the Frenoh troop withdramn and roplaced by a 20cally reoruited Baar gendarmer10, as contemplated by seotion 30 of the sear statute. 46 The army of oooupation was eteadily dininished after February, 2980, but never complete withdramn. Those who remalned were called "rallroad police." Fault, as chairman, mainteined that it would be impossible to tind four thousand logel saarlanders to serve as offleers; furthormore, the Territory could not afford the cost. The Coverning commiesion rotained the Frenoh troop unt12 it could organize the looal gendarmer1e, but stated that they would have the status of garr1son troops and not that of troops of occupation. 47 The $100 a d$ gendarmerle was constituted by a deoree of the Governing cenmiss10n Ju2y 7, 2980, but the Frenoh troops were st12 rotainod and court-martial procoeding and deportation order by the military authoritles were sanotioned by the Goveralng Commission. 48 The Governing Commisetion defonded its decision to rotain the French troops on the ground that it was required to frovide in all cases for the proteotion of persons and property in the saar Basin. 49 Nevertheless, the retention of Frenoh troops gave substance to the Saarlander' compleints. The League Counc1l approved the Comalesion's rotention of the French troops as a temporary moano to the proteotion of 21fe and property. German propagandists made the mont of 1t. The derman Government addreened to tho League of Nations aeries of proteste agalnet 14.50 The covorn-

467reaty, Part III sec. IV Annex Par. 30. 48" Hrat Ropt. Gov. Com." op. glt.. No. 2, (Mar, 2980), p. 104. $48 \mathrm{Op}$. alt. End yr. No. 7. (1920). P. 684. So bid.. p. 684. soln...J." 4th yr. No. 3, (1923), p. 368. 
Ing commiseion in ite observations on the German note reiterated the Impossibility of reoruiting an edequate gendarmerio on aocount of the young won belng attracted 1nto incustry and bocause of the expense 1t would Involve.51 the $100 \mathrm{~s}$ gendarmerie would be Inoreased as the financial altuation might allow but the Commission was convinced of the nocessity in any case of retaining the garrison force of 4500 men in the Territory. 52

8ir Austen Chamberla1n, Britloh Forelgn Secretery, proposed at the League Counc1l Heoting Haroh, 2925 that when the Sear pol10 reached the strength of 1,000 won the French troops should be withdrawn from the Saer, but retalned near the frontier, and that the sear Governing Commission should be given authority, in the erent of serlous disorder, to call in those troops. Seargemund and Forbach were only ton k120meters frow Saerbrücken and therefore the Franoh troops could be stationed withln quiok re0.11. 58

In engwer to 81r Austen Chamberlain's proposal the Counc1l In Haroh 2925 rosolved:

"The Council of the Loague of Nations, after having heard the Italian representative's report, the observations of the representative of Great Britain and the explanations of the presIdent of the Coverning Comiseion:

(1) Approves the Governing Combesion's proposal to increase the local polloe by 250 won during the sinanclal year 1926-1926.

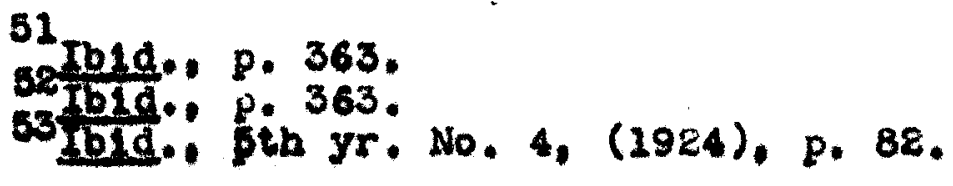


(2) Requests the Gorerning Commission to submit to it for consideration a report on the manner in which it would be poselble, In the abeenoe of troops, to carry lnto exfoct aub-paragraph three of paragraph 30 of the Saar Aanex to the Treaty of Versa1210s, which lays down that 1 t $\$ 111$ be the duty of the Gorerning Comission to provide in all cases for the protection of persons and property in the Suar Basin. In proparing 1 ts report, the Coverning Commisiton should take Inte soovant the poseibility of obtaining the assistance of troops stationed oute1de the saar Territory.

(3) Requests the secretary-General to commanicate a copy of this resolution to the Oerman Oovernment, in reply to 1 to note of Fobruary 19, 1925."

Tho Governing Comnise1on's report of January, 2986, emphasized the sarious nature of the responsibl21ty imposed upon it by the Treaty of protecting 11 fo and property in all circumatanoes; stating that suoh rosponsibility could not bo not without a po11ce force of at least 3,000 men; objecting that the I Inanoiad resources of the saar territory were not equal to the provision of so b1g a force. It quoted the deolation of the Councll of the League of Nation of February 13, 1920, whereby the Counc12 was empowered to demand the malntenance or the recall of the French troops, In whole or in part, to preserve order in the saar, pending the Constitution of the pollee torce prescribed by paragraph 30 of the Saar Annex; steted that the polfce foroe had now reached the 21mit in strength imposed by the I Inancial oonditions,

54 Dold.. 7th yr. No. 4, (Apri1 1926), p. 527. 
but that it was insdequate to meot the full Implications of the responefbilities imposed upon the Commission of safeguarding persons and property "In all oases," and thorefore submitted that the Commission should be ontitied at any time and immediately to call upon troops otationed outside the territory, but near to 16 .

In the same report the Commissi on went on to quote paragraph 33 of the Saar Annex: "The Coverning Comission ahall have power to decide all question arising from the interpretation of the preceding prorislons......." It stated, as 1ts own interpretation of that paragraph, that in caes of noed it was ontitled in an emergenoy, on 1to own reaponalbility, and immediately to oall upon troops atationed outside the Saer Territory to protect persone and property within the territory, and partioulariy to protect the aining installations and tho railwey aystem, the use of which, in the Commission's view, ought to be areguarded in any contingenoy and by all ava1lable and appropriate means. It therefore formulated as 1 ts considered view that only the power to eall in troops from without the torritory could enable the Contasion to discharge one of the most Important obligatione conferred upon it by the treaty. The report onded with a statoment that the Comassion had asked the Frenoh Government to withdraw from the Baar territory a battalion stationed at saarbruoken so that the garrison would be reduced to one regiment of infantry and one of cavalry. 56

56 sefold:. p. 528. 
On Maroh 18, 1986, the Lague Couno11 coneldered that report. The rapportour announeed that the Frenob Government had confirmed the Information Biren by the Saar Commiseion about the French troops in tho Saar, and had also doolared that the w tharawal of the troope that remalnod in the tarritory would bo effocted stop by top. He onded with a sugestion that pending the completion of the Frenoh withdrawal the Governing Commiesion should be reminded of lte duty to sareguard in all cases the froedom of trans 1 and transport over the rallways of the sear territory, and that the Coninasion 1 tself be invited to subalt proposal. In that sense in time for the next mooting of the Coun011. 57 The Couno11 theroupon pased a resolution "noting" the Goterning Commiselon's report and approving tize susgestions made by the repporteur. 58 The proposels thus invited srom the GovernIng Commleston were made avaliable to the Counc12 Harch $22,1927$. They were abodied in a new report dated February 28,1227 , to whioh the saar momber of the Govorning Commlest on had rofused to agree. 59 It proposed!

(1) that thore ahould be placed at the Commiseton's diaposal apeolel Rallway Commission whose activities must be limited to the protection of rallways, telephones, and telegraphs, and a -pecial dofence force of 800 men whose exolusive purpose it would be to eafeguard tranelt and traneport through the Saar territory:

(2) that in the event of any danger arialng to the saar rail57 , N.O.J., 8th yr. No. 2, (Tob. 2987), p. 163.

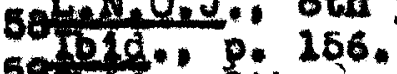
59.10X.". Bth yr. No. 4, (Apr 12 2927), p. 404. 
82

nays, tho rallway oomission should have at its direot alsposel not only the apectal defonce Fores now proposed, but almo two bettalions of Fremeh troope to be etationed outside the territory at saareguemines and Forbach, the partloular duty of thoes battalions to be the proteotion of oertain speoifled eectore of the Saar railway 11 nes. 60

The Lague Coune1l at that meeting pased a rooulubion which pronised that the proposed Falleay Comission and Rallway Defenoe Foroe should be constituted within meximu delay of three months. and therefore the troops statloned in the Saer w221 bo withdrawn wthin that period." 61 The particular need for a pecial foree to defond the rallwaye arose from the olrounstances that the 21 hos of communioation of the Fronch Army of deoupation in tine Finineland passed through the Saar torritory.

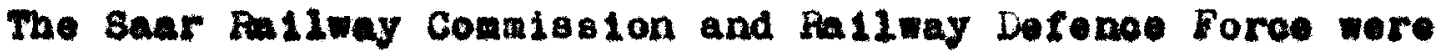
duly oonstituted eceording to the Counel2's resolution. The Detenee Foroe vas composed of conlingente from the Fronoh, BritInh and Belglan Armies of Oooupation. It arrived at saarbrioken near the end of June, 2987, by whiob tine the remnants of the Frenoh troops had boen withdrawn frow the territory. 68 at the end of 1929. the British Army of Oooupation left the chineland. and the Rallway Defonoe Foroe thereafter was composed only of Fronoh and Belgian troope.

Then December 12, 1930, following the evacuation of the Fhine Provinces in June, the Hallway Comidelon and the Rallway

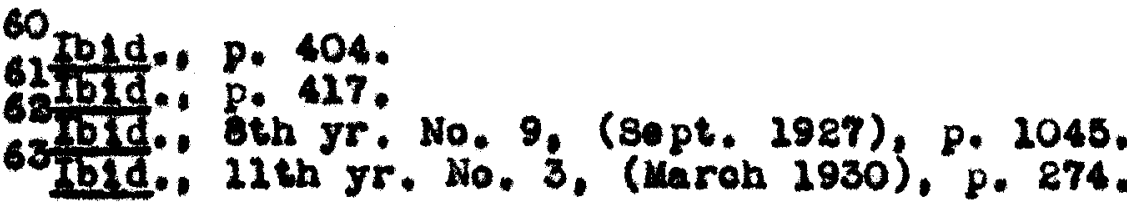


Defonce Force left the Saar Territory. The malatenance of peace and order in the saar Basin was thus loft entirely in the hands of the Govorning Commise 20n, the 20021 pelloe and the gendermerio. In case of emergenoy the Commision could call for help from Fronoh troops within oasy roach frow Saarbruoken.

At the Loague Counc1l meating of Soptomber, 2934, the late M. Barthou, then Fore1gn Minister of France, declared that Franoe "had no intention of repudiating or erading her obligation $1 f$ an appeal be made to hor." 65 The revelant tacte were that the French troops were posted ready for aotion; that the saar GovernIng Commission regarded itgelf as ontitied of of its own right and Independently of the Lague of Natlons to call upon them in case of need. That right was not disputed by any party except Qermany.

From the beglaning there was hostility between the Governing Commlesion and the people over whon they were appolnted to rule. Protests by Saar inhabitants to the Counc1l of the League at Geneva orentually brought some rellef, idarch 24, 1928 the Couno11 granted the requests of the Saarlander for the creation of - Saar Parliamant or Adrisory Council (Landearat) of thirty representatives elected by Inhabitante of the Territory for a throe yoar termi and to grant the right to rote for members of this advisory counoll to all persons more than twenty years of ago who could claim the atatus of "inhabitants or tho Saar." 66 65Ib1d., 12th yr. No. 1, (Jan. 2931), p. 9; 101d:. No. 3.

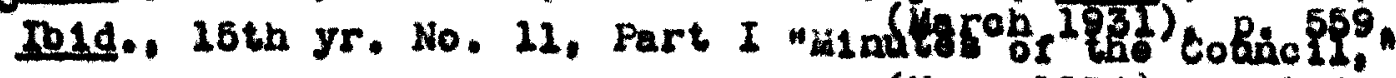
${ }^{66}$ Do1d.. 3rd yr. No. 5, (May 2922), pp.413-15. (Noy), p. 146\%. 
The qualifioatione for seat on the Advisery Counell vere: Persons must be more than twenty-rive years of age, and must be native inhabitants of the Territory "who do not 8111 any -10ct1ve or pub210 post outside the Saar Territory..." The Cha 1r. man was to be appointed by the Governing Comission from among the Inhabitants of the Territory. 67 The Advisory Counc12 was to be convened by the chairman of the Governing Commiseion, wae to mest at leest overy three monthe, and was to be presented at the time of 1 ts convocation by the Chairman of the Governing Comalasion, w1 th agenda to which it must confine $168015 .^{68}$ The jurladietion of this body was 21 mited to changes in oxisting lawe and natters of taxation. It was densed the right of initlative or Interpeliation. Any disoussions on other subjects was to be considered null and vold. "In partloular, all disoussions, notions, or resolutions tending either directly or indirectiy to affect the 1egal ituation oreated in the Saar Territory by the Treaty of Versailles or by the subsequent deorees of the Governing Commeslon thall be null and rold." 69

The eleotion of members to the Adrisory Counctl was fought on German party Ilnes, resulting in the cholce of 16 Centre (Romen Cathol10), 5 Soolal Domoarat10, 4 Pooples Party, 2 Communists and 3 other mombers.70

The Commiseion also oreated a Teobnical Committee, consist-

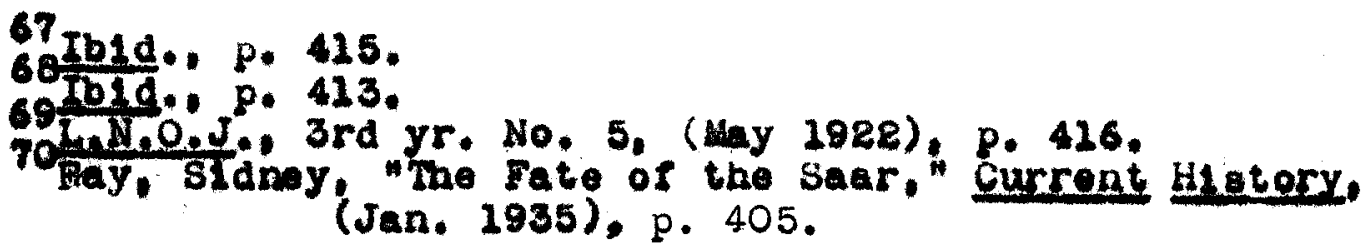


Ing of eight nembers appointed by the Comalesion for one year. 72 Ite nembers were to be nat1vo Inhab1tants of the saar, and it was to advise the Commiesion on all logisiative matiors which the lattor might seo it to refor to 14.78

The nemepapers and political parties in the Territory bitterly attacked the deoree esablishing the Advisory Counoll and Tochnical connittee. 73 Thero was a deand thet the Advisory Counoll be given the right to put questions, to present grievanoes. and to partiolpate in the drawing up of the agenat for its meot. 1ngs. Other demands were for the right of 1nitiative, and garILmentary immantty. They alao objected to the appointment of the Chalrmen of the Advisory Councll by the Coverning Comisaton. They objected to the establishment of a Teohnioal Conat tree as being "an ant1-democratic institution--the object of which was to discount in the eyes of the world the wises expreseed by the - Lected representatives of the Adrisory Couno1l. 74 Tho Docasion was need also for the purpose of drawing attention to old grievanoes which hed not been remedied.

\section{BDUCATION}

No other 1eaue, probably provoked more bltterneas and andwosity than the question of the Frenah echools. "Under the control of the Governing Comidesion the inhabitants $\$ 112$ retain the1r 200al assonblies, their religlous 11bertie日, the ir sohools and

71 op. g1t. 3ra yr. No. 5, (May 2928). p. 416.

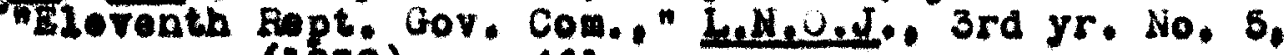
73 (1630), p. 461 .

"Tweleth Rept. Gov. Com." Ibld." 3rd Jr. No. 8, Part 1 74 (1931), P. 768. D.19.. No. 9, Pp. 1046-58. 
the ir languge. "75

"The French state sholl always have the right of establishIng and maintaining, as inoldental to the mines, primary or technical chools for Its employees and their chlidren, and of causIng instruction therein to be glven in the Fronch languege, in aecordance with suoh ourrioulum and by such teachers as it may soleot." 76

An acute oontroversy has raged around these two artioles in the Sear Annex to the Treaty. They wore not Intended to be incompatible, but the action of the Frenoh Government and the interprotation pat on the Artioles by the Governing Commission produced a groat deal of trouble for the Loague. The Saurlandere complained that the Frenoh used politioal and economis presesure to Induce the Inhabitants to send their chlidren to French sohools at the mines where they might be weaned away from their natural loyalty to dermany. Plotures were olrculated showing bow the Fronch provided buses to traneport oblldren to their soloole wh1le those who attended the German schools had to walk. Necording to the Germans they have tried to attract the children of the native aerman population by all kinds of privileges such ac the national schools cannot offer, for instance free school outItts, clothes, less eqvero discipline, great laxity in case of non-ationdance, prom1se of rewards to Individual ohilaren 15 they Induced othor ohlidran to attend the Fronoh sohools. Th1s means, according to the Germans, that the very foundatione of the saar 75. Verealliee Treaty, Sar hnnex, Par. 28. $76 \frac{\text { Iftan. Par. }}{16 .}$ 
Territory settlement as la1d down in the Troaby was abaken and that one of the most important clauses of the Treaty was aetualIy rolded. 77

In Dotober 1920, tho Governing Commision apointed a oomaltee of resident professors and teachers to draw up acheme for the reform of public education which would take into acoount the whes of the Inhabitante who nere anxious for a uniform systom. 78 A priest of the saar Territory wee placed in aharge of the Department of Educatien. 79 July 10, 1980 , two decrees were Iesued by the Ooverning Commiseton. 80 The irst decree permitied oblidron of employees of the ulaes Administration, regardiess of nationality to satiefy the oompulsory education requirement by attendenoe at the sohools of the Mining Administration. The eesond one allowed oblidren of persone not mployed in the mines to fulf 111 the oducational obligations presortbed by law by attendanee at these schools. 81 The Commission atated that this step was taken in response to numerous requests from parents of Germen nation 11 ty to allow thalr ohildren to attend the sohoola et up by the Mines Aduinistration. 88

In 1928 to meet the neede of pup12s who desired bsfore 10 arm Ing the primary sohools, to prepare themalves for golng to seoondary sohools in whioh Frenoh 18 compulsory subjoot, cpoolal clesses in French were orgenized in addstion to the rogular

77, N,O,J, 4th yr. No. 4, (Apr11 1923), p. 415.

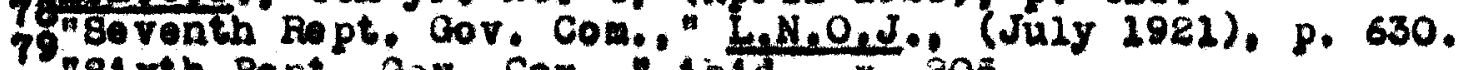

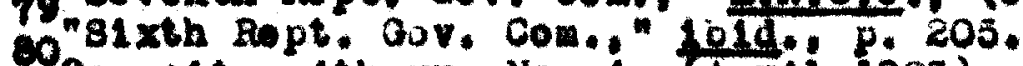

81Op. alte 4th yr. No. 4, (Aprii 1923), pp. 417-20.

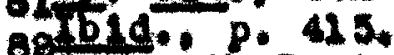
goventh Rept. Gov. Com." L.N.O.J., (Aug. 1921). p. B30. "alghth Rept. Gov. Com. "1blde (Oot. 1921). p. 846. 
courses in rrench. 83 To trein the stalf required for these courses forty teachers were sent to the racation courges in France at Boulogne-Sur-Hor and Nancy to Improve the ir knowledge of Frenoh. The selection was made from those, who as a result of a written and oral examination were elngled out as the best qualifled. These persons vere all volunteors. In addition, a oertain number of speolal courees were instituted for less-advanced teachers who ulght desire to toach Fronoh. 84

As a watter of raot. evente proved that the number of parents desiring to have their ohlidren educated at the schools walntalnod by the French alnes was by no moans negligible. On Jamuary 15, 1983, the total number of chlldren on the regloters of theae sohoole which are only twenty in number was 4,408; of these, 3,798 were of German nationel1ty including 8,286 ohildren of employees of the mines.

These Irgures aleo show that the existence of the national schools in the Territory were in wo way endangered by the growth of the schools malntained by the Mlne Administration. The total of 4,400 praplie muat be compared with the number of pup1la attendIng the national schools, amounting to $223,000.85$

A higher technical sohool was also establishod so the people of the sear rerritory aght be ablo to oomplote their profeselonal education in their own country. 86

The Governing Commission pald considerable attention to ed83" "It ghth Rept. Gor. Com.," 1b1d., (0ot. 1921), p. 845. 8tbid.. p. 845.

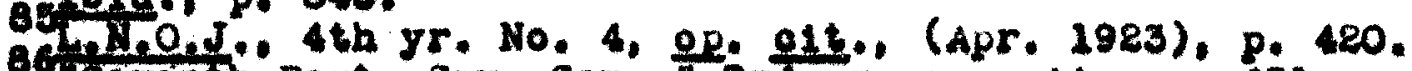

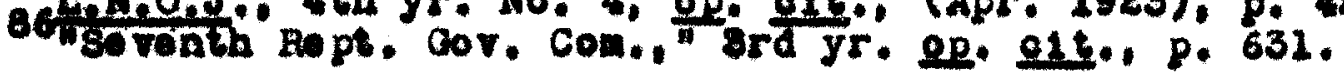


veation. Its reporte to the Comell give opglous information on the education reform and the development of vocational traln1ng. During the yoar 1926 the san authorit1es sent a nuber of teachers to the Fhine Provinoes in order to aequalnt themselves wh new German wethods.

The Department of Education studied tho propagation of the Lague 1deals. It odited a paphlet on the history and prinolples of the League and on sultable nothods of instruotion on the subject in publio oduoation. This pamphlot was sent to a 11 teachers w th a olreular reootaending that onliarea should recelve in-truetion in the extatonee and alms of the Laguo. The Department of Audoation a 280 sent a certain nunter of teachers and professors to the international courses organized at Geneva. 87 In Apr11 1930, the Centre aroup of tho Saar Advisory Coun- 11 subitited to the Governing Comiesion a oompla int sonoeratas ortain caces of preseure exereised in connection with the enrollment of pupizs in the primary sohoolo of the Fronch stato mines in the saar. It was assertad that oertain miners had been urged by teschere or off 10182 of tise mines to eand their ohildren to the wines sohool, under more or less explicit threats of uppleasent oonsequenoes is they falled to do so. 88 There aocu* atione are hardly abbtantiatad by the emallness of the number of Gorman chilaren in tho schools, more than wale of whom, too, are not oblidron of niners.

The Governing Conmission also bed before 16 e dossier subo 87.n.0.j. 8th $y r$. No. 3, (Marah 1987). p. 303 .

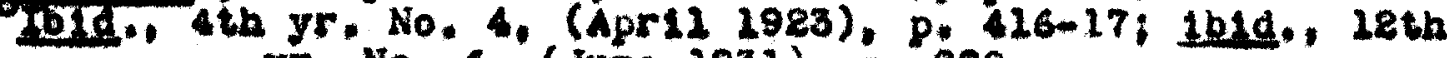
Jr. No. 6. (June 2931), p. 992. 
alttod by the uines Administration, making similar complainte agalnat cortain toachers, nember of the olergy and munlelpal administrations. Who were acoused of having brought prosoure to bear by various means on the parents of chlldren attending the mas schools. It is impossible to declde to what extent these allegation are well founded. 89

The Governing Combiasion orcorec an inquiry to be carried out as a rosult of which it found That, as regards the Centro group's complaint, the inquiry had not provod that dirsot or indirect pressure hed been exerulsed upon tise minors to induce them to send their ohiloren to the mines sobool; that the daministration had falthrulzy observed the Goveruthe Comatsston's declarat1on of Fobruary 6, 1925; that, at the ast, a few subordinate off1c1el. or maters of the mines achool way have acted contrary to this doolaration; that, as regards the complaint of the Hino: Adulnistration, the oharges wers in wost cases not proved, but 1t 1. Tound that certain aotiritiog were contrary to the Coverning Comilasion's declaration of Bubruary 6, 2925.

The cosmisston also noted the propaganda carried on for or againat the mines sohool, but was of the opinion that it had nolther the right nor the power to lorbid propegenda, provided no unlawful means were used. It acked the persons congerned to rotrain from any aots or words whloh might agpear to involvo compulsion, and to arolic oven ans appearance of such compulalon. It added thet the attor was solely one for the froe decision of the ${ }^{89}$ Iblg., 4th yr. No. 4, (April 1983), p. 426. 
parente, and thet this deolsion must be unirerseally respected. 90 In 2934 the Education Department, in ite anxiety to provent

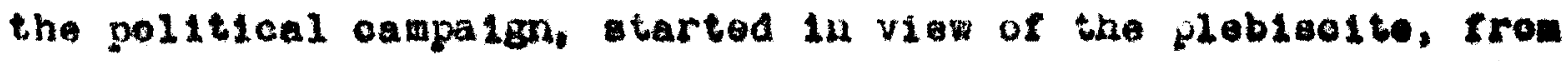
Inveding the sohools, was compelled to take rerious steps. These Inoluded the probibition of leave of absence for politioal exoursions of pupils eltier in the Saar or outalde the territory strloter instruetions regarding the prohibition to introdue schuol text-books without the previous approval of the aupervisory authority: proaloition to stop instruotion or to deoorate tho sohoola on the occasion of political festivals; promibition for the school-ohildren to sing polltiond songs wion walking out under the auperviaion of thoir tonebers; inatructions to the teacho ing otaff and to the chlidren regerding their relation with Jowiah ohilaren; prohibition to diatriblite tracts in the sohools without the opecial approval of tho iduoation Depertweat: problbition for the teaching staff and the pupla to bring political uniforma or badgee into the sohool; prohibition of politieal propaganda vithin the sobool and at echool festivals organlzed by the sebool outside tho ochool ostabilshments. 92

${ }_{91}^{90}$ Ib1d., (1930-31), p. 195-6. p. 2135 . 


$$
\begin{aligned}
& \text { CHA TEK V } \\
& \text { THE POLITICALSITUATION }
\end{aligned}
$$


CHAPTER V

THE POLITICAL SITUATION

On all important 18sues that have arisen in the Saar the 2eaders of the prinolpal politioal parties and the most influm ential newspapers of the Territory have made common cause with the Cerman government against the Coverning Commission. The German Government has sent notes, the political parties have dispatohed petitions, memorlale, and protesting dolegations to Geneva; and the local press, as well as the German press out-1de the sear, has constantly attecked the Governing Commisgion and 1ts pol101es.

On November 25, 2923, certaln political parties represented on the Advisory Counc1l sont a petition to tho League oomplainIng of proponderant French influence in the government of the Territory, and oritleized the economic and financial policy of the government as well as 1 te handling of the housing situation. 1

The nowspapors and political parties bitteriy attacked the decree eatablinhing the Advisory Counoll and Technical Comittee. The political partiea represented at the first meeting of the Adrisory Couno1l grasped the opportunity to revien their grioranoes against the Governing Comisalon. The Centre Party stated that the Advisory Council "11mits our political rights much more

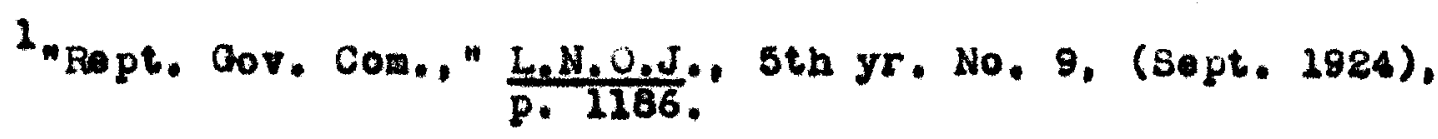


atriotiy than does tho Treaty of Versaliles, "R Their ohiet conplainte were to seoure "the withdramal of the Frenoh broops; the abrogation of the deoree defining the status of a Sar Inbabitant; the abolition of the French schools in their prosent form; the withdrawal of the foreign off101ale in the service of the Saar adminiatration; in short amplete reversel of the Frenchifying polley which has been sollowed hitherto." The oondition upon wh1ch the Centre Party would oooperate with the Governing Commie- Ion was the fulfiliment by the latter, "In a opirit of striot neutrality the mission ontrusted to 1 t by the League of Nations; to have no duty and no interest other then the welfare of the Saar Territory."

The Domooratio party held the opinton that "no cooperation oan serve any useful purpose unless the Joverning Comission completely change the polloy which it has nitherto pursued. This polioy, the sole aln of whlch was to separate the saar Territory from 1te mother country, has produced a deep sense of disappointment in the people of the saar."

The social Democratic party protested aloo "agalnst the establishment of a Teobnioal Committee-can anti-democratic Institution--the object of whioh is to discount in the eyes of the world the wishes expressed by the elected representatives of the Landesrat" (Adrisory Couno11).4 The Social Democratic party lald down the following condition:

"The Indiepensable condition for the comporation of the Enopt. Gov. Com.l Lbld., 3rd yr. No, 9, (Sept. 1922), 3 Ib1d.. p. 2046. pp. 1046-52. Ib1d.. p. 1048. 
Social Democratic Party is that the Governing Commiselon should cease to follon the French annexationtat poliey, whlch loade it openiy to propose to transfor the suar Territory, in elfteen years, into a country polltioelly and intellectually ripe ror annexation to Franoe," The pokenen of the other parties expreseed simlar sentiments."

Binoe 1920 the political history of the saar has been a long series of proteste from political parties, labor organizations and publio bodies, agalnst what thoy have coneldered attempte to deprive them of their national institutions, and to force them under the politioal, oultural and economio Intluenoe of rrance. The Counoli of the Lagkue of Natione was burled ander an unceasing strean of petitions and objections, coming from both the Saer and the Reloh.

These activities greatly increased attor the advent to power of the National Soolalist party and the approach of the plebiocite. The Radioal-Soclallst party belleved that the ollmination of political oontroveray over the future of the Saar would make possible an coonomle agroement with Germany. Th1s polnt of viow was much in evidence during the Franoo-cterman rapproohoment in 19261929. In 1989 the radicel "Llque dee Lrolte de 1'Hegme" made a otudy of the saar question and in Ite sindinge adrocated the ebandonment of tho plebiseite. It wished to wee the return of the saar to German soverelgnty, and an coonomic agreement between Germany and France that would saleguard Fronoh 1nterest. september 87, 1989, Ariatide Briand opened with the Berman Government 5to1d. P. 2048. 
offlelal negotiatione which had been prepared by a long preliminary exohange of views between stresemann and hinself. These negotlatione prored sut1le. Strosemann died October 22, 2929 ; the Briand Government was overthrown and the promiership pased to Tardiou,

The ostablishment of a lational Soclallot gorernment in aormany affectod the attitude of the Frenoh radicals. Hany of those who were unroservedily in tavor of an imtidate return of the saar to Gernany adrocated the maintenance of the atatus quo on the ground that it would mean defeat to the Kitler rule.

In July, 1933 the Deutsohe Front ceme Into existence as a

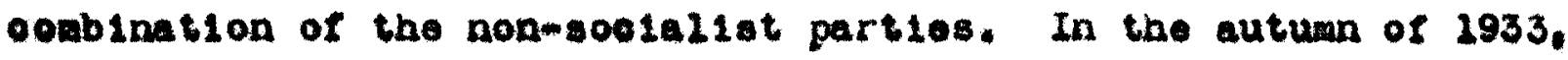
212 parties in the Baer, with the exeeption of the Social Domoorate and the Cosmuniste, disolved, nerged themselves in the Deutsche Front. It numbered about 450,000 persons, claiming that it reprosented 93 per cent of the future pleblaclto roters, and controlled the polloy of most of the sear newepapers." The Deutsche Front was oxtromely woll organized and had ramiflcatione all over the Territory. ' Bach member was cormeliy registered, had a mombershlp card, and pald wonthly dues of one tranc. The unemployed peid ton contives. Inis organization profesed to be above party and to havy ns wjoot but the restoration of the saar to cermany. The two most obvious oharacteristies of the saarlanders are that 6 Trey. Sidney B." "The Fate of the sear." Current Hetory. 7.t., O.J." 25kh yr. Ho. 22, Part 1, (Dec. 2934), p. 2647. tord.. p. 2647. 
wost of then are Cathol10s, and that an even larger majority cons1sts of Industrial workers. When the relations botmeen the is and Catholice within the Reloh were otrained, the saar Catholles became Inoreasingly uneaby. In March 1934, thorefore, through the Influence of Papen, then Fieloh Comassioner of the sear, and Roohling, the great Iron magnate of Vólk12ngen, the Doutsobe

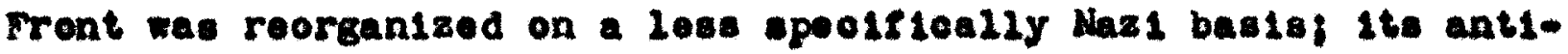
elerioal leader spaniol, was replaced by P1rro. P1rro domanded the malntemance of the striotest disolpline and the avoldance of any breaches of the law, an attitude wh1ch was moreorer essentialif in the tradition of the Saar people. 10 The Deutsohe Front worked with number of advantages. In the first place the searlandere are obriously derman by race, language, and hablts, they natura $22 y$ resented the presence of French troope, they reeented Froneh oftiolals in the Lague administration and in the mines whloh were, according to the Peace Treaty taken over Irom Gormany by the Fronch State. The League Comises on which is not only international, but also authoritarian, aroused ineritable Indignation. The second advantage of the Deutsobe Front my be desoribed as the praotice of Nazl tooknique. Germany placed un21mited runde at the dieposal of the Naz1s of the saer. The Cerman wireless deolared that the saar was imporerished by 1 ts neparation from the fwioh and would te ruined if 1 t was not returned. ${ }^{21}$ Without doubt many jolned the Deutsohe Iront simply beouse they

2071orlnoky, Mloheel I., "Tho Suar struggle," (2934), P. 233. 20 Tb1d.. D. 236 .

12 Inkewann, Elizabeth, "In the saar This sumer," The Gentenporary Revien, (sept. 2934), pp. 327-18. 
Loresaw unpleasantness after January $1035 .{ }^{18}$ The troatment whleh the onemies of the Nazis in Cermany recelved at the bands of the Dovernment was not without its effeots.

Ot the three large morning papers which 0all theselelves "organs of the Deutsobe Front" only one, the "Deutsche Front" is der1nitely Naz1. The other two, the "saarbrioken 2e1tung" and tho "Landes-Zo1tung," were mueh more reserved the "Landes-ze1tung," an orgen of Roman Catholics, orten spoke sternly of tho ooniliot between Hitler and the vatiean. The Deutsohe Front therotore wade Ite right for rounton wh chermany not booause it ondorsed the whole of the Hitlor polloy, but bevase 1 te members balleved that the Saar 1s German and mast go back to Cormany. The Leader: of the opposition parties and the oditors of the opposition newepapers complained of recelving memeing lotters, but they continued noterthelese to go about unmolested and very much as they pleased. 18

There was no orgenization or eampaign for the union of the san with Franee. Those who opposed reundon were wade up of eeveral olemente united by their common refusal to be inoorporated In Germany under Hitler. The Deutsche Front oalled them "separatisten. They were supporters of the stetue quo. The on2y proFronoh elewent in the opposition was on organizetion in the clty or searloula, organized by Dr. Heotor. It olalmod to have a merahlp of 10,000 and many more followers. The political

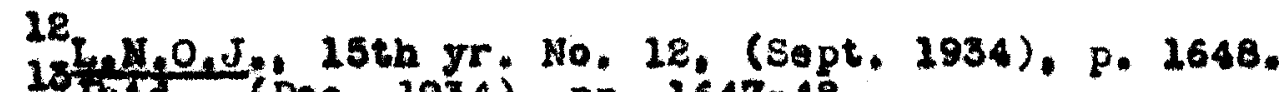
IbT.*. (Doc, 1934), pp. 1647-48. 


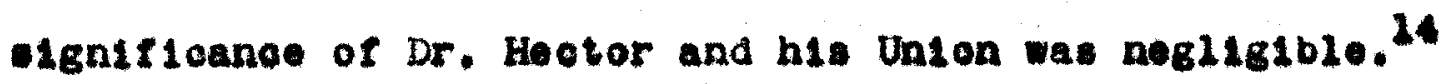

A loose organization of the socialiote and communists known as the Fretheltefront or anti-Faselet front was far more important. Ite roougnized leaders wero Hax Braun, of the German Soolal Domooratio party, and Fritz Ftordt, Comunist. Hax Braun was a etaunoh supporter of the Oerwan cause before the rise of Hitler. He mainteined that the saer was German and that 14 wanted to go back to Oerwany, but not to Hitler's Gormany. The Braup program comprised three pointe. Ho demended a demorat10 gyatew, perhape with a Loague Cominaloner et the head of 16 , to replace the Coverning Conemieston; the insertion in the Saar's nex oonetitution of provision for a now plebleolte, to take place wthla given number of years; and lastly, the joint ownership of the alnes by the French and the saar dovernments. Simliar V10we were expresecd by Frite Pfordt, 2oader of the Communist party. Both belleved that the saar was German and must go baok to Germany, but to a sree Derwany. 25

The third element in the opposition was a seotion of Catholle opinion. This eroup pabilshed the "Neure ganr-Post", nenspaper that began to appear in the spring of 1934. Like tho socialist and the Communists tho "Neure Sagr-Pegt" declared 1 tesif in favor of union with Oerwany but agalngt Hitler. For thea, too, tho statue quo was moredy a tomporary expedient.

The last yeare of the sear interlude were obarecterized by an intenee propegandizing ativity. Mis tine the intiative sut

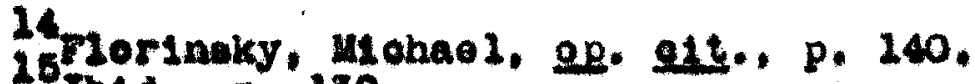
Ip1... p. 239. 
taken by Germany. An underground campalgn beginning after the abort17e rapprochement of $1929-30$, bore 168 iruit in the mualedpal eleotione of November, 293R. Of the 4,301 munielpal oouno11lore leoted that month, only ceven were for a continuation of the atatus quo. If the Saar pleblecite had been held that autumn (Hitier had not yet come to power) it would probably hare ohown a 95 to 5 per cent, perhape 98 to 2 percent, desire for return to cormans 26

The rise of Adolph Hitler had Imeaeurably oomplicated the 1tuation. HLs ILret acts were to oxpol many Jews, to diminiah the power of the Cathol1c Centre party and perseoute the Soolal1.te. Many Jow rled to the saar and began a counter-campaign. Bear nowspepers representing Centre and Soolalist parties at flret opposed Hitler. But they too quickly aucoumbed to the ldea of a Ereater Germany. Conorete manifestation of the strength of the German Front came in Augunt, 2833, when 80,000 Saarlanders at Niederwald demonstrated the ir loyalty to the flelah. By October 1934 impartial observers estimated that 80 per cent of the qualifled voters were nembere of the United Front. 17

The rlee of Hitler also greatly complicated the poestion of the Governing Commision. Binoe April 1932, Geoffrey G. Knox, a nember of the Britiah Alplomatio service, had been tho Conmiesion's Cheirman. The other nembers of the Commiesion in 1932-34, were Dr. Dighrnrooth, FlnLend; Herr Kosaman, Sarr: H. 16Dean, Rdgar Packard, "The Saar and Human Nature," Harpere 17 Ibld. p. 232 . usenglng, (Jan, 2935), p. 233. 
Mor1ze, France; and Dr. Zor 2cle, Kugonlavla, Mr. Knox's predeoessor, Sir Ernest W12ton, had been Very unpopilar and the ohange of ohatrwan was moat weloowe. 10 For a whlle things seemed to be very satiefactory but this did not last lons. The atmosphere became heated and tense by the sharp protests from the pollt1oal parties and the measures taken by the Coverning Commiseion. The growth of the National socialiet party caused the ilrat serlous trouble for Mr. Knox. As head of the Department of the Intertor he was direotly rebonsible for police measures, although the more important declelone were submitted to the Com miesion. In the auner of 2932 the Governing Comiseson prom hiblted barohes and night drilling, and put severe restriotions on the manufacture, posseselon and toring of explosives. In November it ordered the Imadiate alseolution of all the National Soolaliat organizations, espelaliy of the storm troope and desenee troepe with all their auxillary oervices, including the Q 20sing of the1r barragks. In Maroh 1933 the Ooverning Conndeclon prohlbited, provielonally, all politioel meetings and lseued an ordinanoe whioh renewed the ban on wearing uniforms and decorations. ban flrat deolared In an ordinanoe of 1988. Th1s moasure was epeoliteally directed agalnet the National Socialist party. All gatheringe of this party, inoluding inrormal evenlag discussions were to ceses unt1l further orders. 19 On May 20, 1933, the Coverning Connisaion Iseued three ordinances which greatly extended 1ts polioe powers. The Deeree lald down 18 mpieteenth Rept, Gor. Com. L.N.O.J., 13th yr. No.9, 19 (Sept. 1938), p. 1558. Ib1d. 14th yr. No. 6, Part 1, (June 1933), p. 719. 
stricter regulationa with regard to polltioal meetings and domonotrationg; 16 empowered the authorities to prohlbit moctinge and processions in certaln cases, or to break them up. $\$$

The Deutsche Front was quiok to capltalize upon the unpopular mores of the Commission, even though thoy were designed colely to safeguard the rights of the people. Thoy dubbed the Leaguo 's admintetration as "Negerregterung" or "Migger Government" with a Kolonial systommoolonies syatem of rule.

When the open air politioal gatherings wore stopped--to prevent clashes between the Commuliste and Brownahirte-- the Nazis promptiy rented every avaliable ball in the territory for $81 x$ monthe-or unt1l the plebiseite was held. They thought to prevent legal asseblage of the Opposition. 21 From acroes the sear's eront1ere--irom Frankfurt, Cologne, Wanhe1m--Nasl radie stations nightly saturated the atr with denunotations of the Lague, Ito Comniesion, France and eren the Plobieol to connittee.28

The mohine of propeganda, oosrolon, and terrorisn began to funotion. The Nazis intenalfied their saur propaganda. There 18 no doubs that Nasl clube in saarbriboken, Saarloule, and other towns were Insplred by Berlin.

Knox reported to the Loague that he sound unimpeaghable ev1dence that Nes olube in the saar corresponded with offlolal last organization in Cermanyt that the letter bad taxed each of the three and one half m11210n members of the German Workers Front

20yb1d., 24th yr. No, 10, Part 2, (00t. 2933), p. 1286.

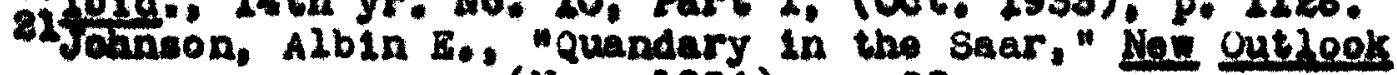
28. (Nov, 2934), P. 22. LeD. O.J.. 15th yr. No. 22, (Deco, 1934), p. 2648; 1b1d.. 15 th yr. No. 10 , p. isei. 
ton cente a month for campasgn funds in the saar. Thousand of dollare orossed the front1ers to buy saer papers, bribe the doubtful, and strengthon the zealote. Hany young mon went frem the sear to Germany to receive training in Nazl military campe. 23 To Insure oomplote anecess in the olections, the Nazis oomanaicated with sarlanders living abroad and offored the trips to the homelend with all exponees pald. The Nazls own praotioally all the newspapers. 80me were so vitriolle in their oritiolam that knox was obliged to censor then; othore coming from Germany were prohibited. 24

A police detechmont, sald to have been led by police commisstoner wachts and aoting under tha authority of tsr. Knox, made aearch of the prenises of the Gerwan Front in Saarbrucken on Juig 20, carried off a quantity of documents, turned off the gese and water, and olosed and sealed the doors. The cermen Front demanded back its papers. A Barr Court of law, after exam Ining thea, ordered their restitution, but isr. Knox olted a olause In an old Prussien law as justification for rotaining then, thus bringing himede into diroct conflict with the saar courts.

In a Liter to the League of Nations, wade public on soptiomber $I_{1}$ and giving extrects from the selzed papers, is, Knox declared thet thoy oontainod eridence that the Germen Front was watalnirae constant relationo with the Naz1 authoritios in the Re1ch; was ongeged In esplonege; that somo 16,000 young searland23 potd., 28th yr. No, 12, Part 2, (W00, 1934), p. 2656. 24Doan, Edgar P.. op. c1t.. (Jan. 1935), p. 234. Fay, sianey B., De. ALE.: (Jan. 2935), p. 406. 
ors had been serving in the German Labor Camps and that ho reared thoy wero gotting a mlltary tralning and might try to use force at the time of the plebiselte. The German Front and the German government publishod statements alming to show that h1s sueplolons and reare were without foundations, 26 Moreover, Fronch troope olose to the frontier were prepared to intervene if the Nazis had attempted any kind of a putrech on January 13.

A dozen different thread weare in and out of the thisled skein which goes to make up the economic, political, and cultural fabris that is the Saar today, all or any of which oould have hopelessly snarled the beet lald plane of pleblsolte campaignors. Aside from sontimentalism and emotionalise, that inderinable affection for the land of one's birth, the tongue of one' ancestors, whlob alone would have been sufficlent in pre-filtLer deys to ratee 98 per cent of the volces in the sear for Germany, the religlous element was unquestionably the most potent factor 1mediately before the plobisolte. In estlmating the role the churoh oould bave played in the determination of the future status of the saar one met take into consideretion the faot that the Imhabitente of the territory are about 73 per cent Roman Cathollos.

The assasalnations of Erie Kleusener, politioal ohlel of Cathol 10 Action, and of Adezbert Probet, head of the Catholic Youth Movement, the outlanry of the Centre Party of ex-Chanoelzer Bruning, the persibtent persecution of Cardinaly raudhaber and other rel1glous leaders in Bavaria, the Fhlneland,

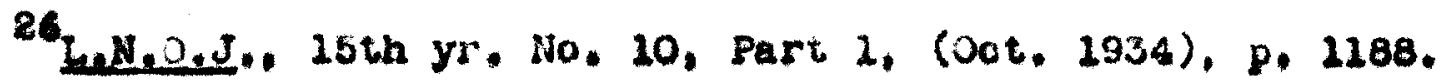


the saar and the Pelatinate, kindled a resentment whioh w121 smolder for years. 27 The extreme importance of the catholle question in lte bearing on the lapue of the pleblsolte was reoognized both in the Saar and in Berlin.

Torn by oonflicting political passione, orushed between economic millatones, dominated by deop-rooted religlous conVlotlons, the saarlander bad but ono common anohor, thelr ractal homogenelty with gormany. Aooording to O, C. Knox, Chairman, of the Corerning Board, 2,000 additional pol10e, reorulted from noutral rogions, wore needed to malntaln peace and order, "Without then the 'free, secret and truetworthy' plobisolte preseribed by the Peace Treat1es guaranteed by the Loague Counoll and 'promloed" by Berlin w112 be a farce," Knox and, His long-atandias plea for additional pollee was granted when an International aruy of 3,300 troop were reorulted from sngland, Italy, Sweden, and Holland, to keop peace between Franoe and Germany during the suar Torritory Ploblacite.

27 Johnson, Albin E., op. Q1t.. (Nov, 1934), p. 19. 
C HA PTER VI

LABOR AND SOCIALRULATIONS 
CHAPTER VI

LABOR AND BOCIAL RELATIONS

Soolal condition in the Saar are largely determined by the oharmoter of tho distriot, whioh 1 s that of a bighly developed and donsely populated industrial rogion. Agriculture 1. of minor importance, the saar belag oapable of producing only part of 1te domestio requirements. Three-fourthe of the population are engaged in trade, Industry, commorce and rallway work. The miners and their familles alone constitute a third of the total population.

One third of the minors own their hows, many of them possessing land and oattle, whereby they are onabled to alleviate the hardship of oritical times. There is a strong in0l1nation, unequalled anywhere else, on the part of the workIng population to settie pormanentiy in the saar Territory.

The density of the population ( 432 inbabitants per square k1loweter), dus to the conglomeration of b18 massen in a comparatively small area, is three times as high as that of the rest of Dermany (139), and even hlgher than that of angland (264) and Belgiun (266). I In the wide saar Valley, as well ae In the sulzbach and Fishbach valleys, between saarbriloken and Nounkirchen, the center of the coal mining industry, an unin-

Icartell1er1, Dr. Wilter, The Territery of the sear, Chicago Tribune saar supplement, No. 2, (June 12, 1934), p. 8. 
termpted succeses on of sottloments and v1llages 18 to be found overywhere etretohing for many k120meters along the highways. And yet the land of the saar bas preserved its manifold scenis charme, partioularly in the lower Saer Valley, along the kiver Biles and in the Warndt reg10n. The risitor, prepared for the banal aspects of an industrial center full of nolse and smoke, cannot fail to be pleasantly surprised by the harmony between Industry and the rurel landscape. One third of the country is at1ll donsely covered with torests. Prince wilnolm-ieinrioh von Nassau-Saarbruoken, one of the former rulers of the land, Introduced, In the middze of the elghteenth contury, the use of coal and charcoal for combustion, in order to save the rich woods Irom destruction. The eining distriot proper borders to the north and outh on the agrloultural reglon of the country, the population of whioh oupplies the industrial centers with a coniderable contingent of workers. ${ }^{2}$

Nearly 200 years ago the Pruselan mintng administration alded the einere in aequiring land and howes. Often this ald was extended through a miners" soolety called the "Knappoohatt," whloh dates from the middle of the elghteenth century. Thls organization has bohlnd 1 a tradition of accompliahment and progrese. Wombers of this knappsehart, as in cortain lodges of America, wear distinotive uniform on gala daye-ma bjack relvet coet, het with badge and reathers, a miner's lamp and a cene. For more than 150 years all Saar miners wo have been in every Inta. 
way mon of good repute have been eligible to join the Kasppsebaft. It grante pensions to won pest so, and alds members in buying nomes. 3

In this way thousands of dwe2ling bouses passed Into the ownershlp of the workers, many of whom also kept 11 re stook on surrounding pastureland. About two-thirds of the married workmen belonged to th1 olass of small holders before the war. The Fronoh adminletration of the mines discontinued the social polloy pursued by the Pruselon Government. Instead of providing the workers with howes of their own, they bullt large tonement houses for them where numerous workmen and thelr Iamllies live olose together. In other rospects, the soolal status of the Sear workers deteriorated in consequence of the post-war changes. If It were not for the contributions reoelved from Germany, the social 1nsuranee syste of the Star would hare disoontinued.

Les than ten peroent of the sacr population earn the ir 117ing trom the tarm. Some ninety per oent spend all or most of tholr working houre in mino, mi11, trade, tranaportation, or al11ed pureuits. Before Industry absorbed so many, Saar workmen used to tranp all over middle Europe es peddlers, tinkers, and doere of odd jobbe.

M. P. Waelbroeok who made for the Ifternational Labor oftion a most interesting Investigation of industriel relations in the Frenoh mines of the Saar, writes: "In this mining country, whe "siapich, Frederick, "mat Is The Sear," The Nablengl Geotrpla.. p. 248. crophte Uscezing, (rob. 1935), p. $2 \overline{47 .}$ 
ooal has been used for Industrial purposes for over a century, a real alning population bas come Into existence whose ocoupation 10 honored above all othors so that a young man, as ale, has no ambition other than to follow his father down into the pit as soon as he has reached the proper age. Hany workers employed in other Industries, even those in which they are better pald, suob as the bullding Industry, would be happy to go down Into the alnes, if only they could gain admiseion." In the saar minos omployment has almost a hereditary oharaoter, paselas srom father to son. 5

saar mining offere oertain edvantages which one does not alway find in other industries. The most important is the seour1ty of employment. Once admitted, the miner is reasobably sure that be w112 continue to work unt11 the age of rot1rement, whioh 18 about fifty, when he begins to draw a pension. In recent yeare howerer the situation has changed to his disadrantage. The Fronoh Adminietration carried on a work of remorganization whioh deoply affected the alners in their work. The adminiatration achlered considerable succese in increasing the per capita production of the mines. This was done by applying to the minos the prinoiple of efflolenoy. It was not accompanied by an inorease in total production and had the soctal coneequence of Intensifying unomployment. 6 Drastio obanges wore diotated by the depreseion in the coal market and the acounulation of coal. They were also aooompanied, beglaning in 1927, by a mass dismissal of workers. The first to go were miners realding outsice the territory of 5Morinaky, Mlchael T., The sear struggle. (2934), pp. 91-2. Ib2d.. p. 57. 
the saar. The other groups to 1080 their jobs ineluded men who were eligible tor ansion and those who had a better chanoe of finding other employent. "Mining aleo offers opportunities for advaneement and higher earnings. The standard wage of a fullfledged miner is not reached unt12 a man has worked under ground for six years, his rate of pay inoreasing in the wantime every two yoara. Highor rewards are pald sor professlonal sk121. In the oompatation of monthly wages thore 10 kept open a variable whioh reflects the average productirity of the worker in the couree of the conth. Finally he bae the opportunity of obtainIng the position of "orerman" by studying in the special olasses maintained by the mining administration.

To we how thoroughly ae ran the regloc 1s, in speech and sentiment, one has only to mingle with any holiday orowds and I1sten to the songe, the speahos, and the mele, or read the papers, or soe what orowds 11sten to radio broadeasts from Frankfort and stuttgart.

On any anniveraary of the battles of 1870, some of whlob were rought hereaboute, one sees men in old style Prince Alberts and top hats waking speeches, bands playing taniliar German alrs, and orowds slooking out to lay wreathos on the war monuments about searbricken.?

From the econonic polat of V10w, the situation in the Saar Torritory, during the year Ootober, 2926 to October, 1927, pre-

Trold., P. 96.

Tbta. p. 94-5.

simploh, Froderiok, ep. Q1t., pp. 245-46. 
sented certaln diffioulties owing to rapld appreosetion of the Irane, which caused some disproportion between the economis conditions and the export requirements of the Territory. The main effort of the Governing Comisesion bore accordingly on the economio adjustment of the Territory to the new monetary conditions. The prinoipal noesures taken were the roduction of the price of ooal and rallway tariffs, the ostablishment of opectel tariffa for the export of Saar produots to Germany and ria Antwerp, and a reduction of the income taxes. They were acoompanied by a tall in wages and a 0171l service salary reforw.

On Norember 20, 2986, the Frenah and Derman Governments oonoluded an arrangenont for the parpose of adjusting the saar oustoms rogime to oonditions resulting from the oreation of the steel Truat. This arrangemont gare the saer Ilnighing industry oertaln export caolistion as regards Cermany and onabled the Latter to export duty-iree to the saar oertain products and machlnes. The measures resulted in an improvement of the sitwation, more partioulariy as rogarded the cost of living and the labor market. Nevertheleas, the diftloultiee experieneed by the coal mine in marketing their produote did not disappear. 20

The conoluedon of the Franco-German Commerelal Treaty of Auguat 17, 1927, was an event of considerable 1mportanoe for the Territory. The German and French Governments agreed to begin negotiations in Ootober with a vien of adjusting the FrancoOerman agreement on the commercial operations of the Territery 20 The League of Nat1ong trog Year to Year. "The saar," (cot. 1026-27), p. 134 . 
to the situation ereated by the now comerelal wroaty. ${ }^{22}$ The work of the Commiesion was not 11mited to enouring the eoonomio prosperity of the Territory, or to measures agalnet unemploywent. Dwell1nge were bullt to cope with the howalng erisis; a general road improvement program was executed; the number of telephone lines between the Saar and Cermany, and the Saar and France was 1ncreased; offlelale were appointed to study methode of Intensire oultivation; a lood inspeotion office was creatod; hoepltals were onlarged and Improved; and rellet was provided for warmdieabled and war viotime.

In the economio 1102d, the most 1mportant erent during 19871928 was the elgnature of the Franoo-berman agreemont on comarce between the saar and Oermany. Th10 agreement extended the Gerwan warkots for the Saar hoery Industries and the I Inlehing, prooelein, glase, chenioal and tobacoo industrien and provided frech markets for the furniehing and paper industries and the agriouztural produets of the northern part of the Territory. It replaced variou provielonal arrangemente, and regulated the entire trade between the saar and Germany. The Commission stated In one of its reports that it was "a guaranteo for the stability and the developeent of the economic 1190 of the Territory."

The European coul orisis made it difficult for saar coal to find a warket and the state Mining Administration was obliged to Introduce compulsory daye of unemployment and to disoharge a certaln number of norkmen. Between Ootober lat and December

12Th1d.: p. 135 . Ib1d.: (0ot. 1929, to Nov, 30, 1928), p. 209. 
31, 2928, approximately 3,800 workers were dismlesed, 2,000 of whom were inhabitants of the Territory.

In pite of those disoharges, the effectives of the saer wines remalned hlgher than the 1920 rigure. Towards the middle of June, the number unomployed only amounted to 2,005 as wh 4,285 in April of the samo year. To aseist the discherged workaen, the Governing Commisesion deesded, In March 198B, to employ then on Government or subseldieed work.

It began nogotiations with the French government for the revieton of the 1984 Regulations concerning the contribution of the mines to the sear budget. The Governing Comiseston oam to an agreament with the French Governeent besed on the maintenance of the status quo as regards the contribution of the mines to the budget of the Territory. In oubeoribing to this arrangement. the corerning Commiasion bore in alnd that tho depresalon in the ocal market would wake it diffsoult to inorease the burdon of the mines, and that any new taxes would reoult in a rise in coal priees in dietriets where there was no oompesition, wore partioulariy in the Baar basin 1 teele. 13

The nueber of unenployed roee trin i2,900 in Docember 1930 to 24,800 in llay 2081. These Rigures are twies as blgh as those for the oorreoponding monthe of 1930. The epproprlatlone for unemployment rollef, however, had been baced on the 1930 siguren. The Coverning Comiseion was therefore raoed with a deflest, whloh was inoreaned at112 further by the ralling off in ra1zway trast10. 24

13.019.9. 210.

14.0.0.J.: 15th gr. No. 4, (Apr12 1934), p. 399. 
As trofi Ju2y 1st, 2931, and provioionally until april lat, 1938, the besto galaries and allowances of officlels were reduoed by six per cent. Although their salaries were $11 x e d$ by the Loague Council, the memere of the Coverning Compisaion apontaneously deosded to give beck $1 x$ per cont of thoir aciaries to the saar Territory. In the hoarymotal industry and in the saar mines, the collective wage contracts were denounced and wagea were redueed by approximately $2 \mathrm{Lx}$ and one-balf per cent. 15

The ceneral budget adopted for the elnanolal year April 2at, 1932 to Laroh 30, 1932, showed a total expenditure of 521 mil210n Irano with a credit balanos of approxinately 1,400,000 erancs. In order to balance the budget, a sum of about 35 mi111ion eranes

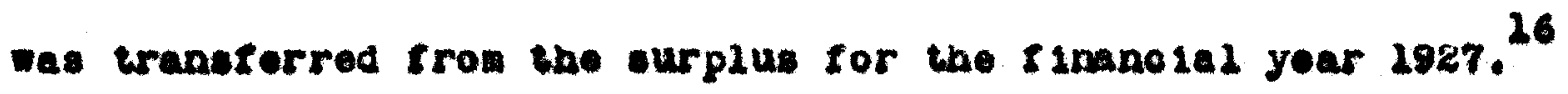
The assets of the Governing Connisesion amounted, on Harch 10th, 1931 to $180,000,000$ erance derived from the surplus of previoue finanolal years. The eapltal expenditure for purposes of general ut111ty amounted to some 74,000,000 francs. The t1nanolal situation made it neceseary for the Comasesion to exeroiee oven eroater care than hithorto as regards the liquidation of 1 ta assets.

The Governing Comisesion stated that only the reserves buldt up In prosperous yeare with a V1ew to meoting omergencles enabled it to arold or postpone reoourse to turther taxation. 17 In the opinion of $M$. Weelbroeck, the trade unions were large${ }^{15}$ The Leasue of Astiong Froe Year to Year. "The saar," 16.jo1d.. p. 295.

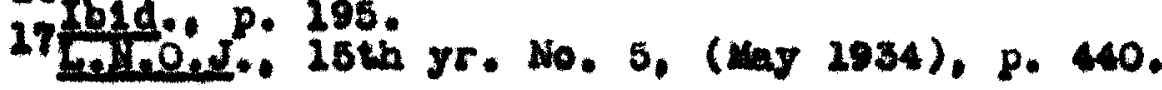


1y instrumental in making 2abor ccoopt wlthout a protest both the drast1e mothods of "afflotency" wh10h so bany resented, and atmultenoous diswiseal of thousands of workers. It was hoped at the time that these ahanges would make unnoceseary any further dismlsals, and thus restore to the remalning workers that soourity of omployment which they so deeply needed. These expeotatione talled to matorializo. In 1910 the sear mines enployed 61,000 men. In 1984 the reoord 11 gure of 75,000 was reached, but continuou doolin set in during the following years. In 2930 the mines oployed 57,000 men; in 2932, 46,000; In 1938, 45,000. In June 2034 the total number omployed was 44,714, at the and of Deoember $2054,45,029,{ }^{28}$ Th1e does not compare favorably w1th the of,000 exployed in 2913, onpeola21y If one takes into oonsideration the growth of the nining population in the preeedins twenty years, No wonder the trade union leadors and tho taen thomelves epeak today with considerablo bitlerness of the effloleny polloy of the Fronoh Admin1 stration. 18

The antive membershlp of the Kngpoughath has been reduoed by 38 por oent with the falling oft in the number of niners omployed, and 2 to penaion list bas inoreased by 68 per cent. In 2934 so 45,000 aotive nembera were supporting more than 26,000 penstonars. In oplte of the aseletance given to the Knappachatt by the Ooverning Commission (3.6 fll110n trancs in 2938-1933), 18.tbid.. No. 9. (sept. 1934), p. 1227.

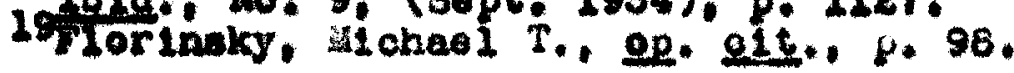




\section{4}

penelons were reduced. These Ilgures, whloh were quoted by KLeter, were widely used in tho plebiecite campaign and they were much nearer to the heart of the miner then elaborate arguuentio about internatlonal exchangea, 20 The introduction of the eovon and a half hour day for underground workers, an achlevewent of which the French Administration is rightiy proud, would have been more appreciated by the men $1 f$ it mad not been 201 lowed by unemployment and the reduotion of wages.

Aocording to Information obtalned by the Department of Labor, the grants by by the Gorning Comission for repairs to dweliIngs provided angiderable amount of work. At a coneervative estinate thoy prooured 73,01E working days. For the I Inanoial year 1934, the Governine comiseston roted a grant of $1,400,000$ franos. 21

\section{TRADE UNIONE}

The trade unions in the Territory of the saar were, Irom the time of their counding, nomber of the central trade union organizatione in Cermany. Wen the Saar on January 10, 1980, was romoved from the admindstrative soverelenty of Germany, that fact did not in the least ohange their relations with the central organizetions in Germany. They remained a part of the cerman trade unl on moromons. The hesdquarters of all trade unione In the saar were in tho derman Leh. The central administrations of the varlous trade unton. In Germany were the Iinal authority 80 Ibid.. P. 99.

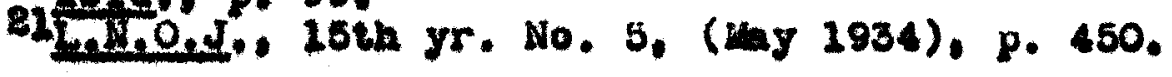


for the nomber organizatione in the saar. Thle arrangement of trade union conditions wet the wishes of the workers in the saar, who refused with the greatest deteralnstion every effort to separate thom from the contral organizations in Gormany. The sear Government Commission had to take account of this determination, 28

The worker's movement in the Saar took as many direoblons as it did in the Reloh. The workers of Chrietian-Nationalist tendenoy belonged to the "Douteoher Gowerksohaftsound," Those whose polities were Soolal Democratio belonged to the "Aligemeiner Doutsoher Gewerkschaftsbund" and Liberal Democratio workers in the saur to the "Deutsoher Gewerkechaftering." In the Saar, the "Deutsoher Gewerkschartsbund" hod the most members and the "Doutscher Gwerkechartsring" the fewest.

Th1s 11ne-up of unlons oesend after Juno, 1933. May 2, 2933 the whole cerman trade union in the Eleh was united in the "Deutseno irbelterront." That put an end to the varying tendenotes of the trade union morement. But tho trade unions in the saar Territory oould not transfor to the "Deutsohe Arbeltseront." The speclel econoulo and soolal oonditione in the saar as well as the Territory's 20 gislation and adminlstration compelled the various trade unions to remaln independent organizatons. Furthermore, changes in the 3aar loglslation covering organization in the Reloh made imposelble the incorporation 82 Kiefer, Feter, "The Baar Workers " Contral Organization," Ghleage Trlbune, Saar Supploment, No. \& $(1934)$ p. 16 . 
of the trade unions of tho saar Torritory in the "Doutsche Arbeltefront." 23 The sear trade unlone, now independent, no 2ongor had oontral organieations in Germany. It becamo doalrable to establieh a new central organization to serve in the best way possible the coonomio, soolal, and general interests of the workers. The all was to unite all existing organizations in one great oerman trade union organtation. On Oetober 21, 1933 the members of most of the trade unlone wo and founded the "Doutsohe Gewerkeohaftesront Sear" (Corman Trade Undone front In the saar). It was joined from the rery beginning by thirtoon trade unions representing all the 20002 industries, seren assoosations of employees working in private enterprises, and three unions of government employees. It represented 73,000 workers of all polttieal oolorings, except the Soolallsts. Ths organization was not Identioal with the "Deutsche Arbeltsfront," but had eriendiy rolations with 1t. Peter Klofor, the wellknown miner leader beoand lte leader. The alm of the new organlzation was the cafeguarding of the workers interests. It also almed to eduoate lts members in the profonsions and trades, and furthor their intel2eotual well-belng. It not only realeted with the greatest determination any effort to separate the saar Irom Germany, but worked for the reinoorporation of the saar in the German RoLeh. 84

23 8trold. 


$$
\begin{aligned}
& \text { CHAPTEA VII } \\
& \text { THE PLEBISCITE }
\end{aligned}
$$




\section{THI PLEBISCITR}

There was something grimiy humorous about tho situation in the saar Territory. On Sunday, January 23, 1935, noar2y 500,000 Inhabitants of the saar region went to the pollo for one of the most Interesting aleotions of the swentieth oentury. They were to deolde whother the saar Basin was to be roturned to Cormany. handed over to Franoe, or romain under the control of the Lague of Nalions. As the saar is rich in coal, and was taken from Gerwany as ar Indomity move to belp France, both cowntries look- d forward to the eleotion with deep interent. The vote itself was not to decide the disposition of the region. After the pleb1801te, scoording to the Treaty, "the Leagu shall deolde on the soverelgnty under which the territory (or any part of it) is to be pleoed, taking into account the wlshes of the inhabitante as expreseed by the roting." ${ }^{2}$ It is ceen from this that great power and reeponeibi11ty reat with the League.

Cerman coneern over the outeome of the January plebloolte found exproseion In a sigantie open-air denonstration at Coblon, on Auguet 26, 2934, In favor of the roturn of the allenated territory to Cermany. The ovent was ataged at th spetacular 120ur1shes. The elty was bodeoked with slage, the streets resounded to the warch of parading leet, plgeons were released, and nos-

Iyerasules Treaty. Seotion IV, Annex Par. 35. 
sages of good-w111 arrived by relay runners trow polnte soatter-d all orer Germany. The bigh epot of the oscasion was apeoch by Adolf Hitler in whieh bo urged his auditors, wany of whon had travellod from the Baar itself to hear him, to rote for tho return of the sector to the tatherlend. Ho mado a bld for tho support of rellglous organizations in the sear by deolaring that he stood for the froedos of the ohuroh, provided it did not moddle in politica. Bron Frenoh aselstance was called for, on the grounds that a "redemption" of the ood distriet would remove one of the major obstacles now etanding in the way of Franoeaermen eriendehlp."

Chaneel2or BLtler made it no seoret that bo was anxious to rogaln the sear as soon a poesible. Ho did not wish to wait unt12 the election and propoesd that the Frencin reach an agreoment ith cormany whloh would turn the Bhar over to that country lawediately. 3 The Frenoh, naturally, refueed, saying that the matter rested with the League of Nations and that the procedure deeided upon after the war would have to be oarried out. 4

Whon the Counc11 of the League met, 1 to most important task was to set in wotion preparations for the holding of the plobisolte. And 1 was then that the gravity of the eltuation eame to 1ight. Petition wore f1led with the League by saar residente requesting that aotion be taken to prevent the Nasis

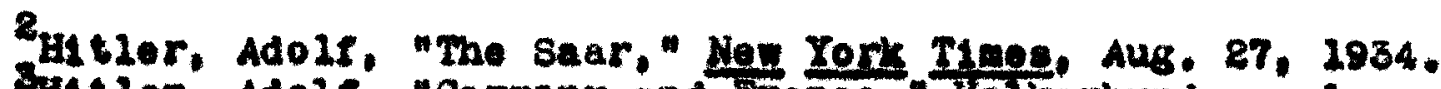

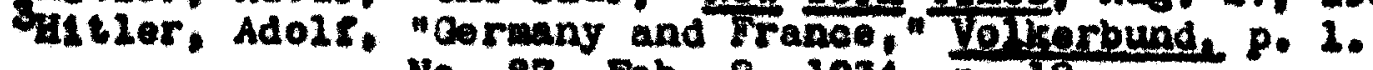
4 No. 87, Fob. 2, 2934, P. 12.

Bditorial Correapondence, "Peace in the Baar," The Christian centiny, Vol. LII, No. 1, ( Jan, 2, 2935), P.8. 
from intinidating the pooplo of the dietriet. 5 It was charged that Germany was exerting suoh "intolerable prossure upon the population.....that there ean ne longer be any gusation of freedow of opinion." The Nazis, it was sold, throatonod to treat those who voted against union with Germany as thay hare treated Jews, Conmuniste and other enexies of tho Hitler government in Germany. The worde "atter 1935" became a souroe of terror to wany saar rosicente. 6

The Hitierites did overything they could to ssouro result rarorable to then, Thoy accused the Frenoh and the League Corornm Ing Commiesion of disoriminating against thom. They sald that the majority of the people in the saar wanted to be rounited with Gorwany, and that other powers were dolng overything they could to keop this from happening. In juotice to themselve tho Nazis Insieted that they must give battle to those foroes whloh seek to degriva then of what 10 rightfuzly the 2 rs."

It Is obvious that when the Counoll of the League of Matione met in January 2934, to consider preparations for the plebiecite, 1t was faced with an exceedingly difrioult task. On the one -1de the re was atrong sentiment for the placiag of an international police rores in the saar aran during the timo of the plobisolte. Coupled with this was a desire that Germany be re-trainod frow Intimidatins the saar inhabitants. On the othor wes cermany's refuel to oopperate with the Lague and her al-

5.H.O.J.. "Petition sent To secrotary-Oeneral," (Doo.

"Tb2d.. "Pet1210n' Sent To Couno12 of Loague of Nat1ons," 7 (Dec. 2934). pp. 1684-25. "Intd.. "Potition To Counoli of League of Nations," (Not. 1934). p. 1219. 
ready expreseed wlah that the sar be turned over to her before 1935. And on a third alde was a desire on the part of many saar realdents that the pleblecite be postponed for ceveral yeara. or at least until a tair vote could be assured.

It we up to the League to compromiae the se conflioting riews. The French were anxiouo that gtrong action be laken, but tho BrLtish and Italians vero unw 1 llikg to offend dormany. Ascorcingly the councli ald the usual thing under sush oondition. It drew up resolutione turning the whole matcer of studying prem parations for tho saar plobiscito over to a apecial comibalon. This oomiasion, oonsiating of repreaentatives of Italy, Spain, and Argentina, was set up to cuparviee the work of ensuring a regular eleotoral procedure, to provent undue presauro and Intimidation of retere, and to consider suggeations from tho covern. Ing Commieston of the Bat on tho malntenance of order during

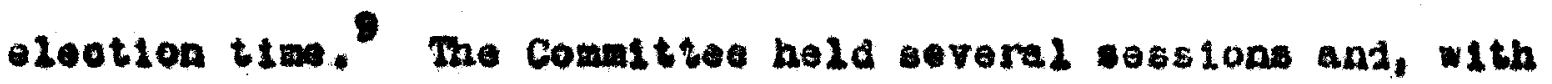
the ascletame of vartoas axperts. Laid down the regulation for the ploblacite on June 4. It took note of the Eranco-cerman

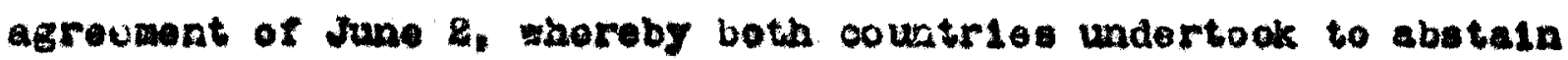
from preasure on voterw or inposing reprisele on thom, to take - tepe to prevent simlar aess by other parties. to poralt an appenl of etther alde to the Permanent Court of International Justiog, and to allow the suprome Ploblolete Court to exemine oeses of oomplatint ageingt intinidation and proseuro sor a year

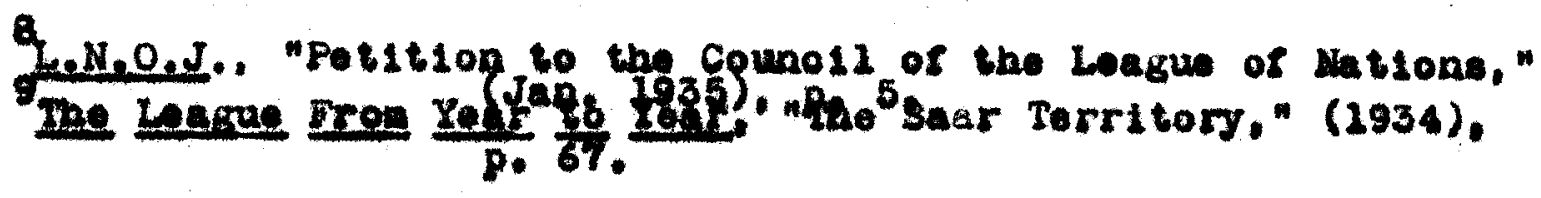


after the pleblected. 10

A Plebisote comienton was aot up by the Counolit for tho aetual organiation of the plobiecite. Th1s Commisaion consieted of three nembers and an expert, who way act as deputy member. The fol 2owing were apposnted mombers of the Conmiselont M. Danlel de Jough (Dutoh), M, Vlotor Honry (Sw1es), and H. Alan Rohde (Swedlah), with ulas sarah wabuugh (U.8.A.), as teonnical adviser.

The ohalrmanohip of the Commission was beid in turn by mombers; the Commiselon took Its decisions by a mjority vote of the nombers present. It bad the power to appoint and dism1se the staft, lookl or forelgr, noceseary for the performance of 1te dutles. The Commiselon began work on July 2, 2934, and set up a bureau of offlotale in eaoh of the elghty-three voting areas. 12

Foriations for the plebisol te related to the toliowing pointel the right to vote, the statue of resident, the roting divisions, the loosl bodies to be establinhed in oonnection with the plebisolte, the compliation of the roting 210 ts, the presentalion of olatmo in oanneotion w1th the roting 118t, Joting procodure and the troatment of porsons oomitting offonoes under the regulations.

It was at the age time latd dowa that, in the prcrlaton that "a rote 111 take place by cosmanos or distriets." The result of the voling to be determined by unlon of communes or, 10 mid.: p. 68.
21 itg. 


\section{8}

In the pase of oomennes not forming part of any union, by oommunce. Each unton of comrunes and each commune which did not form part of union constituted a roting area. In eaoh of the areas thus formed, the voting was ondeulated soparately. $2 \mathrm{c}$

There were eight Distriot Bureaux oonsisting of one or more off101alo appointed by the Plebisecte Comisesion with the oopourrence of the Comultee of the Counoll (Baren Aloles' Comattee). These offlosels were not natives of the Sear, Germany or France. A delegate of the Distriot Buroau eoted as chalrma of the conmunal conulttee set up in erery roting dietriot. Thl oommittee wa reaponsible for compling the regleters of persons entitiled to vote. The members of the Committee were appointed by the Plebsectite Comittee. ${ }^{13}$

For the roting 1tself, a 2arge number of roting off100s were established. In each of these, there wore two officlal tollers and two aseistanto, with a ohalrman not belonging to the sear, Germany or Franoe, 24

Thore was also a Plebisclte Tribunal consieting of a suprene Plobieol to Court and elght Distriot Tribunale with jurladiotion in dieputes oonenralng: tho ontries in the rom gletere of pareons entitied to vote and the validity of the rotingi offences covered by the Ploblselto regulations and 1RLANCO.J." "The Baar Territory," Part II, (June 293k), 13 P. 669.

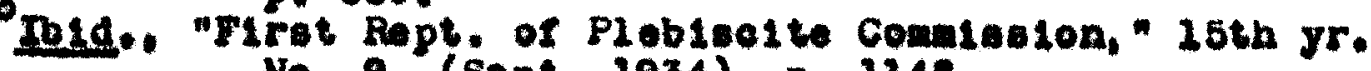
24 No. 9, (sept. 2934), p. 2146. Dold. "Inguiations for the Plobiect to," Annex 2 art. II, 15th yr. 10. \%, (30pt. 2934). p. 2158. 
breaches of ordinary oriminal law, in so far es they are conneated with the purpose of the plebiselte, comitted before, during and after the plebicelte preceedinge. 15

The Pronident of the supreno Court is 4 . Bindo Gall2 (Italian), and V1eo President wr. Jawe Creed Moredith (Iriah); there are $1 x$ other judges and an Exanintag Hagiotrete, a pub110 Prosecutor, two sesiatants and tho regietrars. All of these, together with the juages of the Distriet Tribunale, were appointed by the Prosident of the Coune1l, after consulting his colleagues and on the proposal of the Couno12's Comblttes. The Judges of all these oourts know Oorman, are not natives of the saar. Gormany or Franoe. 17

The supreme Court and the leht Dietriot Tr tbunds began tholr duties on september 26. The suprene Plobleolte Tribunal w112 remain in office during a trameitlokal partod of one year frow the date of tho definitive réglese.

The costo of the plebseoste were defrayed from a peolal fund to whloh Franos and Corwang adranoed 8170 militon franos owch and the Coverning Commiesion one mi210n. As this anount proved Inouffleleat, the Counoll anked for furthor advanoes from the two Gorernmonte. 28 A pleblsol to 20 an expeneive arfair and eren at the septemer session of the Counell of the League the

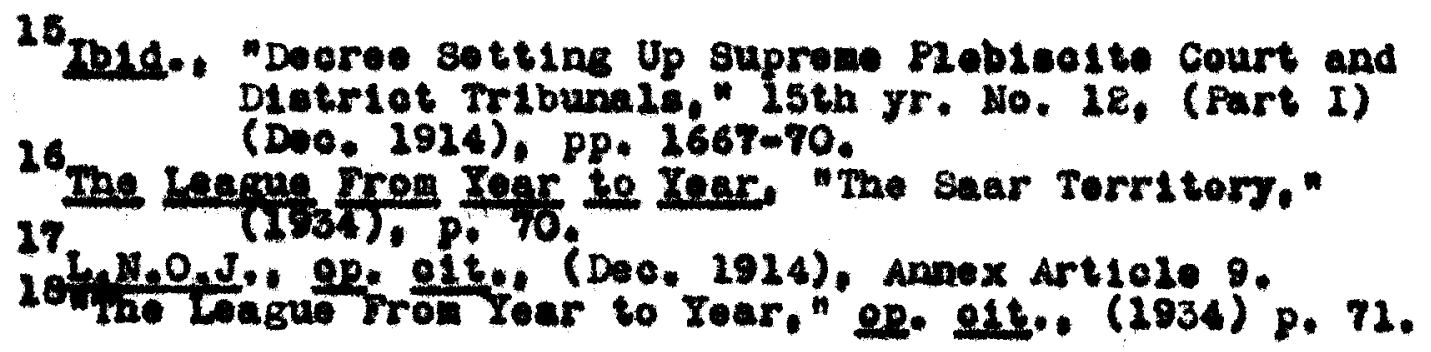


watter of the nocessity of Ineroasing the funds arallable for thls parpose was brought up. The right to vote belonged without dietinction of sex or natienality to all persone who were more than twanty years old at the date of the roting and who posesesed the status of rosident in the Torritory of June 28, 1919,29

At 1t: september moeting the Counosl reterred to its coms mittes the problen of the position of sear offlotale after tho plebiselte; the definition of the oharacter of the rógime to be undertaken if the ploblsolte reeulted in a verdiot for the return to the status quef the problex of the trancer of the winen and of the Frenoh ourrenoy in elroulation in the sear.

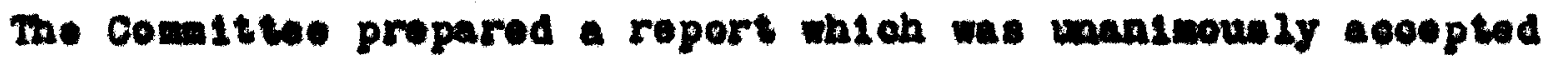
by the Councti on Doosmber 5 . It stated that 11 there vas a return to the statue quo, the Loague would be entitlod to capfor soverelgnty on the saarlanders and 2norease thoir selfgovernment. That the Inhabitants would have the right of optIne for the cerman or Frenoh nationality alnoe now natiomil1 ty otatio for the saar would bave to be eatabliabed. 80 AocordIng to the June agroement protection from reprisals was to be extended to all inhabitante, and no disoriningtion in race, lenguage or nationallty was to be made for one year to Germany.

Two Important agreenents were reached on December 3 betweon

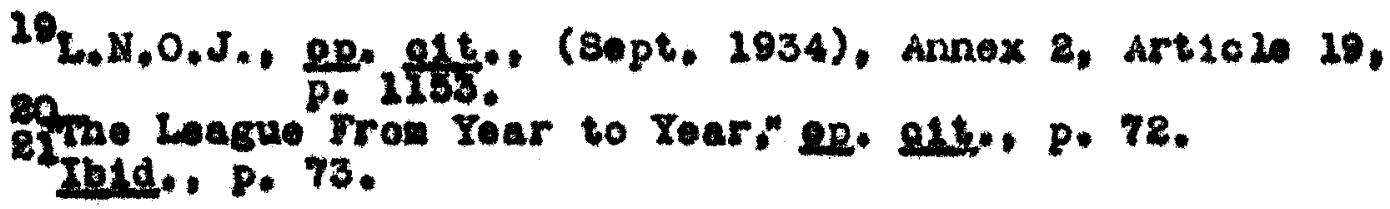


Franee and Germang whioh mede a peaceful plobleol te almost oertain. Tho flrst related to Oerman's repurohase of tho Bear minew, whloh belonged to the Frenoh government, 28 The Verea1lies Treaty provided that, if the plebieolte nent in faror of Oprmany, ahe was to buy baok the mines at a prioe 12xed by experts, paying for thes in gold within a year. 23 Thl bad been regarded as a thorny problen boouse of the diftloulty ot arriving at a prioe that would be regarded as juet by both partice and because of Oermany's lack of funds for payments abrosd.

An agresment, was reacher at Rome on December 3 , between Count de Chambrun for Franeo and Ambaseador Von baseel for Germany, in conouitation with Baron AloLel, tho Italian chasrma of the Lague of Nation's Speotal Comienion on the Saar problen. If the plebiselte went in ravor of Germany she agroed to pay France $800,000,000$ Frenoh france $(\$ 58,400,000)$, as a settlement for the mines, raliways, cuetome statione and all other Fronah oredits in the saur. The Frenoh agreed to acoept 21,000,000 tone of coal during tho noxt fivo years a part payment. Part of the rest of the payment 111 be made by derman acoeptanoe of the Frenoh franot now elroulating among searlanders. German marke will be exchanged for thowe sranos, whioh w121 then be need to pay Jrance. 24

8971..p. 74.

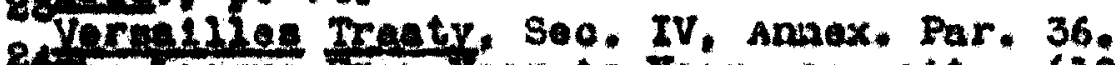

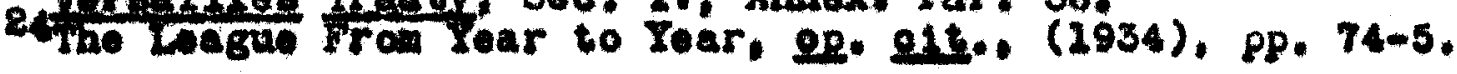


Germany also agreod to extond to the non-roting population of the Saer the same guaranteas promleed to the roting population at Geneva on June 4; to reapeot all rights aequired by saarlandors in regard to sootal insuranoe and state ald; and to oxtend to the whole sear population, regardlese of race, religlon, or political bellef, full guarantees against persecutions or reprisals of any sort for one yoar. Thls guarantes is to be superrleed by the supreme Plebleoste Tribunal. 25

The eecond 2aportant agreement was Great Britain's announose mont at Geneva on December 5 that, eontrary to hor prevlous polioy, the was wiling to send a miltary toroe to ald in preserving order during and imediately after the pleblecite. 26 Groat Britain's offer to ald in polloing the saar was a notable ohift erom her sottled polioy of keoping out of continental affalrs. She advises but rarely acts. In this instance, she evidently belleved preventire masures, however distasteful, were Infinitely more desirable than the risk of a Iranoo-German rupture. The British contingent was augmented by contingents frow Italy, Notherlande, and Sweden. The otrongth of the ocatingent was e 1 xed a tollowa $t^{27}$

United Kingdom.........................,

Italy...............................,300

Wh thorlands............................ 250

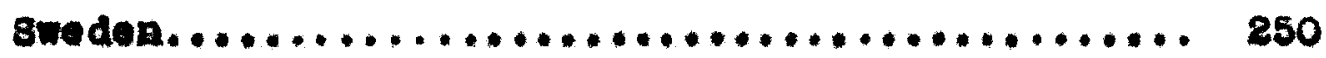

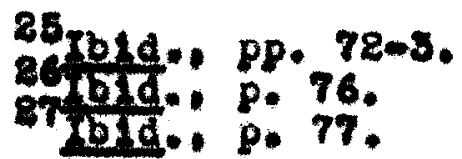


On Decamber 21, It was declded that the foroe should be put at the dieposel of the Governing Commisalon, tho cost to be borne by the Plebleclte rund. 20

The oontingents reashed the $32 a r$ by Dooember 28 and wore placed under the command of Majormeneral Brind (United Kingdon). 89

In epite of all these prosautions, a great number of pot1tlone ware sent from the saar to the Seoretary-General of the League protesting against the inoroasing Nazl Lntimidation and againat the ralsifying of voting $11 \mathrm{sta}{ }^{30}$

About 55,000 of those eligible to vote in the Star pleb10c1te no longer 11 ved in the Saarland. In order to poll as large anrman majority as possible, Germany Induoed many of them to return to their former hoteland and cast the1r vote. The cost of the journey was borne by the Cerwan covernment. It was ost Imated that they represented ten per cont of the totad rote. Thoy cane trom Oermany, France, Aola, AIrica and North and South Amerioam-former Searlanders qualified to partiolpate In the Pleblsolte beoauge they 11 red in the saar Territory on June 28, 1919, tho day the Troaty of Vorsall20s became offeotive. France sent a contingent of 5,000 acoording to the Assoelated Prese, amons whom were a dozen Forelgh Leglonnalres from asrican outposts. More than 600 checked in Irom the United states. 32

$$
\begin{aligned}
& 86 \mathrm{mp1d..} \mathrm{P.} 76 . \\
& \text { Totd. p. } 77 . \\
& \text { Iedforle" "Pet181 on to the Counotl of the Loague," 25th } \\
& 32 \text { yr. Ho, 12, (Part I), (D00, 2934), P. 2682. } \\
& \text { Torolgn Comment, "Ploblacite Day in the Saar Territory." } \\
& \text { The Llterary Dlient, Vol. 219, (Jan. 19, 1935), p.13, }
\end{aligned}
$$


As the tiwe set for the plobisolte approached, tenution inoreased Tielbiy between France and German. The Oerman were acoused of terrorizing the realdente of the sear, of browbeatIng then into voting for union with Germany. In return, the Frenoh were obarged with attempting to turn the tide of sent1mont against Germany. The League of Nat1on was trying to paelfy all elemente of disoerd, and to prepare for an honeat, unblased rote. The diffloulties of this task, in rien of the aggravated stato of affalrs, was apparent.

Thus wo approached the oruolal day. What was the gemeral altuation proceding the event? For woeks Nasis and anti-buzis had hold woetinge and staged demonotrations. Vlolent olachos ocourred from time to tine. All dermany ecomed exelted at the prospective return of a land that not only contained riah ood ninos, but was of ralue from a strategle point of vien, elnoe 14 raoed induetrial France. It is olear that the cay was being 20oked forward to with as wheh interest in othor Buropean oountries as in those imediately involved.

Tho day of voting arrived. If conditlone were bad before 1t. cortalniy one would expeot thon to reach their apex that day. Contrary to adl the searful expectations, the roting in the saar rogion on sunday, January 23, was completed without any breach of the peace. It was a model eleotion, comlag off In the most perfoct oalm. By a majority of 477,220 to 48,637 the Inbabitente of the region Indicated that thay preterred to return to thoir former homeland. The Iland results of the ballotsng, as announoed by tho Loague Ploblecite Conmission, 
were: $i^{38}$

Rogletered voterw.....................539,541

Final vote.................................8se, 005

For German rule....................477,218

For Logue rule.......................46,513

For French rule........................ , $_{1} 284$

Invalid.............................. 2,249

The percentage of votes cast for derman rule was almost oqualiy orerwhelelns in orery dietriet of the saar. 1t was rovealed by tho oopplete tabulation.

The saar pleblest to was an extronely costly affalr. In addition to the hoary expones of tramporting and paytas for a spealel International army of 3,300 mon, there was a hoary e2eotion b121. About 2,000 neutral polle offlelale were pald p68 each and 1lring expenses. Benldes that, Oermpy paid the traveling costs of 48,000 roters who had moved to Germany, and 5,000 who had enigrated overeens, in order that they alght return to the saar and reoord tholr preteronoes. 33

Four days after 90 per oent of the saarlandere had declared In the saer Plobiseste of Jamary 23 their doalre for the roturn of the terrstory to Germany, the League of Nations CounQ21 awarded the whole Saar Besin to Oermany munder tho condition reaulting from" the Verabilios Treaty, Also it tixed larah 1 as the date meor reatebliahment of Oermany in the Government of the gaar region."

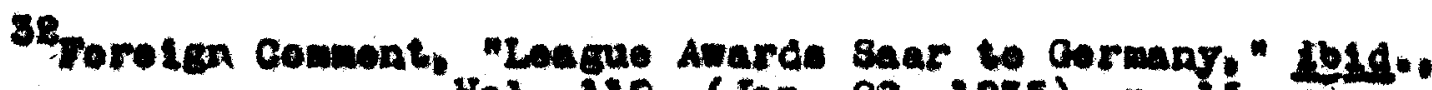
33 Vel. 210, (Jan, 20, 2035), p. 15. Around the World, "gaar," The Anerieen Oberrue, Vol. IV. (Jan, EL, I.855, p. 3 . 
It was roquired that Oermany firet ahould aseure Iranoe that the Nazi bovernmont would fulfil certaln conditions. If Oermany did not oome to an agreoment by Fobruary 28, the Oouno11 announced that $2 t$ would moet in extraordinary soselon to take heoeseary stepe."

The elrot condition inposed upon Germany was demilitarization of the sear by the League's Corerning Commis sion before Maroh 1. Germany was required also to nagotlate, undor the eupervision of the Speolal saar Committee, headed by Baron Pompeo Alola1 of Italy, an agreement w1th France on guarantees for the saar population, the payment of pensions to publle omployees, the transter of mines and similar probleas.

Plerre Laval, Frenoh Forelgn Minister, Indicated at Geneva an additional condition bofore the Councli ahould hand the saar over to Germany. He told the Counoll that France desired peace. "but bistory has shown her that sho must $21 v 0$ in security," and he urged that Germany should enter into an "Baster Loearno pact and agreemente guaranteolng Austria's integrity." 34

At Borlin, WiLhele Friek, German Minister of the Interior, stated that a month would be more than was noeded to acoomplieh the teohnios 1 and adminiotrative takke involving the reincorporation of the Baar Into the Reloh, Joseph Bueroked, Chanoellor Adolf HLtzor's plentpotentlary for the Bear before the Plebleolte, was appointed by the Chancelior to be gorernor 34 rore1gn Comment, 200. c1t., (Jan, 26, 1935), p. 15. 
of that territary. 35

Thore was tromendous excitemont in the gaar region on larch 1. for on thet day this 11tt2e coul-mining region was offlolally rostored to the tatherland, Oermany. Cafes were orowded, parades marobod, and Nasl owastike rlage wore in evidenoe everymbere. A general anneaty for certain classes of saciand prisonors was proolalmed by Chaneslior Hitlor on the ove of natlon-mide ceremonio marking the territory's return to Germany. A oommunique atated: 36

The soparation of the sear from Germany ponetrated so deeply into all conditions of life that offenses for which many were punished oan now be understood."

The amesty troed all porson serving terms of not more than yoar, provided there are no previous convictione against thea. Sontenoes of 10 se than three monthe were repealed, regardlese of cormer reoorde.

Chaneellor Hitier and some of his depaties visited their new sol2, and delivered spesches in the olty of Saarbrüoken. The obaneslior took the opportmalty to doelare, "By thie aot of equality and justloe the way finally bas been cleared for improving our relations with Franos. This is a hapey day not only for Gerwany, but for al2 Europe."37

In the name of the Loague of Nations, whioh adniniotered the produetive area from the day the Treaty of Versallies bocame effeotive. Baron Pompeo Al01s of Italy had formal2y trans-

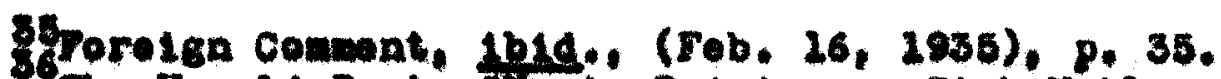

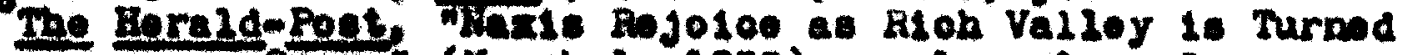
87 O70T." (Haroh 1,2935 ), p. 2, colum 8.

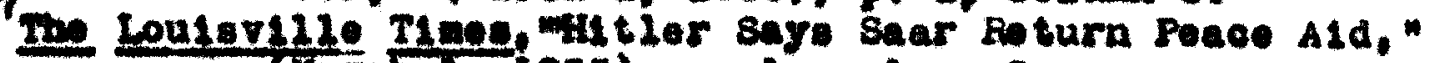
(Taroh I, 2935), p. 2, column 8. 
ferred the torritory to Gerwan wovereignty.

W12hole Frick, Nasi Mntster of the Intertor, aooepted control over the Saar for the Entoh and the mandate of the January 23 plebleet te was fulfilled.

The brief eerenony took place in the Government bullaing

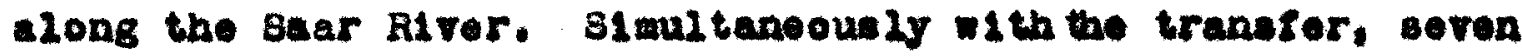
colume of etorm troopers, each 1,000 strong, oroseed the obliter. ated frontior whloh had separated the basin from the homeland. 38 Wh120 the plebisolte mothod commends itself to the Ideal1etio welf determinationist, it is fraught with mumerous dangers and diffioultien. Bren when adequate noutral polloling 1. provided and atisfaotory oufrage qualifiontions and eleotoral procedures are dericed, the referendun iteolf embitters natlonal reoling, oreates temptatione of bribery, oooroton, and terroriem on both aldes, and offere no asaurance that the roters -121 reoord their permanent national proterenoes, rather than their rears, prejudiose, and econonie interests at the monent. Whonever the outoome ralle to correspond to the demands of the peoples thomselvee, locel diseatiateotion, International tonelon, and oontroversies between nolghboring states Invariably onoue. In Fobruary 1928, Prosideat 12son in an addross to congress, asested:

"Feoples and provinoes are not to be bartered about from covereignty to soverelgnty, as If they wore more obattede and parme in the game. Peoples way now be doninated and governed only by their own consent. Self-determination is not are phrase. It is an imperativo prinelple of action, whioh statedemen will henoeforth 1enore at their peril." 
CONCLUSIOA 


\section{CONCLUSION}

In making a study of such a particular problen as the saar. one often gets a wrong perspeotive in regard to the place of tho problem in world affalrs. Perbaps this atudy has given the reader direotly or Indirectly an exaggerated laca of the inportanoe of this problem in the relatsone of the two poples of the two goternments and poselbly even in world events. The controtero -1al nature of the 11terature make any evaluation of the proper laportanse of thle problem a difflenlt one.

It an be a mater of eirot pol1tioal importanoe whother the Frenoo-German boundery 2 ine runs south or north of the sad Alrer, but, then Tlened in the 18ght of geographloal relations,

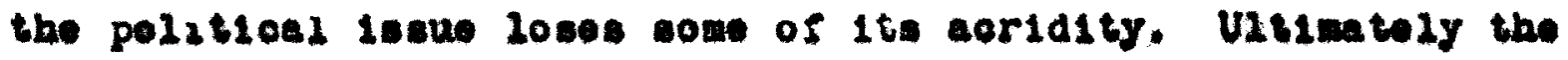
tru boundartes of a borderland area such as the sanr Territory are oontrolied by wae Industrlal planning rather than by ahrond politioal bargalning. Thi "Rormidable bloo de Charbon" Iron

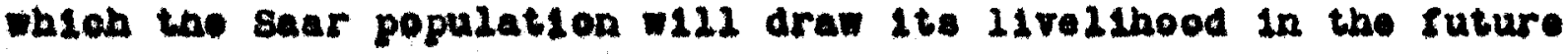
as it has done in the past, is not only goographioally a koy" stone betwen Frenoh and Cerman lande; it 18 aleo destined to

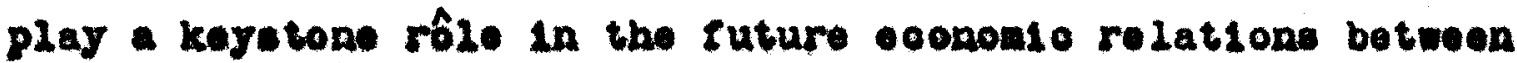
the two great rivale on elther olde of the sanr.

The League of Nation harvested conelderable prestige from 1te experinent in international governuent. On the whole the League Adnlatetration has beon comendable, exoept during tho carly post-nar goare when the Goterning Conalesion was donlnated 
by the patriotio $u$, vietor Rault, who thought it was his duty to aot. not as an Impartial rulor, but as an agent of the French republie. True enough, map Baclanders protested bitterly against being "ruled 21ke negro tribe" and complained that the euggestione of their advisory parliamont were usually ignored. Yot the Vasia themselves admit that under the last three Conalesione Chasrwon-m. W. Stephens of Canada, S1r Ernest wilton of sngland, and coderoy O. Knox-the territory has been governed cheaply and wol2.

It is true that the League Corernment was undenocratio, authority beling entrusted to an International combaton of fire, of whom one was Frenoh and one a seerlender. It was at the peace Conferenoe that the saar had aequired its ingular status-that of a diatriet whose population is Corman, whose oconoule róg1we was Fronoh, and whose government was international.

a. O. Knox, the president of the Commission, an knglishman, had etruggled for more than a year to prevent the saar population fron being latimidated by the highly orgenlzed Nasl propoganda and preseure designed to Inoure olean aweep in the plobiacito. Knox acoused the Mazis of trying to set up a de taoto government in the saar.

If not domoeratie, the suar Gomission bse at leant dono It best to eafeguard the demooratio freedon of the pleblselte, and It had ruled through saar cerman officiale and (alnoe 1930) with a saar German pelioe toree and gendarmerie. Only whon this foroe becane subject to has proseure did the Commselon aek 


\section{5}

for an intornational contingent of troopa.

The sifteongyear Loague régime in the saar has made the distriet an adainistrative unit for the I1rot time in 1 to blatory, has provided good government and brought the saar through tho conomio orials with lees hardship than Germany has ondured. It has performed alffloult administrative taok remarkably wed2 and eupplied an admirable example of international government.

The story of the saar as an internatlonal ward, whose guardlanghlp has onded, way be sumed up by cliting the obserration by one of the ohter Mast egents in the Saar:

"Our troops destroyed coal mines in the North of Franoe. That was a great etupldity. The saer has pald for 1 by beling separated fron cercany for IIfteen years."

The saar has inourred no dobts, its budget was babltually balanoed, and its taxes compared with those of the bordorias - tates, were low. bofore the depression, the Conmisaton was eten able to bulld up a surplus oufsielent to permit a romisBlon of taxes in 1989, and to oarry a good part of the unemployment burdon over alnos. Belief and hoalth service was admirable. and Ilani2y, in opite of the diotatorial torm of government. troedon of opeoch and pross were graater than in alwost any other continontal oountry.

The saer to dependent apon France for the tron ore ueed

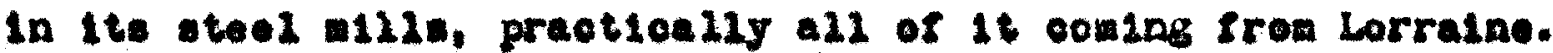
The Baar, Lorralne and Alsace have been withln the save oustome area stnee 1070. Before the World War, all three were Geiman, and alnoe thon all three have boen in tho Freneh oustoms area. 
Binee the saar has beoome German again, it is soparated from 1to two partner provinces by a tariff for the first time in elxty-tive years. The Sear's coal and Lorraine's ore mast orose an coonomic and polltiond frontier 16 the natural and logleal eoonomic oollaboration of the two areas, which 18 oo neceseary to the saer, 18 to continue.

The Nazis consider the result of the sear plobisolte to be a great triumph for the dootrine of German national unity. This dootrine has become veritable religion among large numbers of the German people. The doctrine of German national unity Includes the bellef that all minority groupe of Germane IIVIng outside the boundaries of Germany should be brought into the fatherland. This idea was recently expreseed by Dr. Wilhelm Friok, miniater of the interior, who ald:

- In these plebleoste daye our national duty 19 to remember that beyond the frontiers there are st111 many 12 llons of Germans, just a loyel cermane as the sacrianders. but who, despite an alleged pletery of the right of selfdeterninetion at the ond of the war, without being alced have been lsolated or plaoed under forelgn rule."

It Is largely this bellet that aroused Germany to suoh Intonee exoltement over the return of the Saar. Now Cerman nowspapers are organizing a movenent for the return of other areas that were onoe a part of cermany. They toel that the distriots of Eupen and Mlmedy. whloh were taken from Germany and handed over to Belgium In 1919, ought to be returned. Nazi agitators in these districts have been ataglng parades and demonetratione and the Belglan polloe have made a number of arresto. The return of the Banr to Cermany, after the eo per eent 
rote in the plebiscite, encouraged many Germans to agl tate for Austro-derman unton, Monel, where the German population has been oppressed by the Lithuanians, and the Froe City of Lan218, whose forelga relations are under Polleh control. An International arwy, reaponsible for melatalaing the peace of the world, has been the hope and drean of the pesceloring pople for genorations. Puoleists, etatosmen, and pub110 leaders, heve urged the oreation of a neutral sorce, areed and authorized to impoes tranquililty on quarrelling nations and to prevent nationalistio rivalrios from broaking into war. Ont12 this year, when a corpe of 3,300 troops reoruited from England, Italy, Swoden and Holland kopt peace betwoen France and Qermany durling the saar Territory Plobiselte, no such body had ever extoted. A altuation exactly parallel to the saar Plebiscite had not risen before. Everyone in Aurope want-d pesce. The success of the saar foree has hown one way to help in its preservation. A precedent for international noutral action to provent war has been sot. The IIrst experiment bas been a suecess. The precedent may grow. 
A P P M D X 
APPENDIX

VERBAILLES TREATY

PART III, SECTION IV

SAAR BASIN

ARTICLS 45
As compensation for the destruetion of the coal ines in the north of France and as part payment towards the total roparation due from cormany for the damage resulting from tho war. cermany oedes to France in sull and absolute possession, wth exclusive rights of explo1tation, unenoumbered and free from all debte and charges of any k1nd, the coal-mines 1 tuated in the Saar Basin as defined in Article 48.

\section{ARTICLE 46.}

In order to assure the rights and welfare of the population and to guerante to Franoe complete freedom in working the minea, Germany agrees to the provisions of Chaptere I and II of the Annex hereto.

ART ICLE 47.

In order to make in due time permanent provision for the government of the Saar Basin in aecordance with the whes of the populations, France and Cermany agree to the provistons of Chapter III of the snnex hereto.

\section{ARTTCLE 48.}

The boundaries of the territory of the Saar Basin, as dealt with in the present stipulations, w112 be rixed as lol10w: 
Oa the south and conth-gest: by the frontier of pranoe as Ixed by the prosent Treaty.

On the north-uet and northt by a line followlas the northorn administrative boundary of the Lreis of Marsis from the point where it Leaves the Fronoh frontier to the point where it wete the adminiotrative boundary eeparating the commune of searholzbach from the comme of Britten; following this communal boundary southwards and reachlng the administrative boundary of the oanton of Horzis to as to inelude in the territory of the saar Bas In the oantion of lettlach, with the exeeption of the comiune of Britton; following suceesalvely the northern edministrative boundaries of the eantons of Morzig and baustadt, which are incorporated in the aforesald saar Besin, then sucesestrely the adninietrative boundaries eparating the kreine of saerelouls,

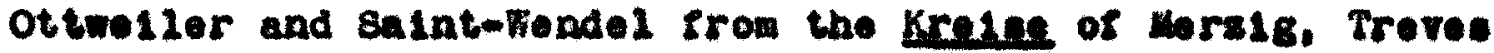
(Trier) and the Prinolpality of the Blckeneeld as far as polat oltuated about 500 metres north of the village of Furechwelier (712., the highost polnt of the Hotaldberg).

Oa the porth-enct and enty from the lant polat detined above to a point about 3t kLlometres eactmorthmagt of saintFondel: a line to be sixed on the grounde paselng east of Fursohwiler, west of Rosohberg, east of polnte 418, 329 (south of Rosohberg), west of Leiteraweiler, northooat of polnt 464, and following the line of the oroat couthwards to its junotion Nith the adainistrative boundary of the Krele of Kased:

thone In a vothoriy direction the boundary of the Xreth of Busel, then the boundary of the Krete of Hosture towards the south couth-east to a point sttuated about 1000 motres west of Dunsweluan 
thenoe to a polnt about 2 kl lometre south of Hornbach:

A 11ne to be flxed on the ground passing through point 424 (about 2000 motres south-east of Dupzwe1ler), point 363 (Fuchs-Berg), point 322 (south-west of Waldmohr), then east of Jageraburg and Erbach, then eno1roling Homburg, pase ing through the points 361 (about if kLlonetres north-east by east of that town), 348 (about 2 kilometres south-east of that tomn), 347 (sohreiners-Berg), 356, 350 (about lit k1lometres south-east of Sohwarzenbach), then paseing east of Einod, south east of points 328 and 333 , about 2 kilowetres oast of wobenhe1m, about $z$ kllomtres oast of Mmbach, paseing east of the plateau which is traversed by the road from Mlmbach to Bockweller (so as to inolude this road in tho territory of the saer Basin), passing Immodiately north of the junotion of the roads from Bookvelier and Althelm sturated about 2 kllometres north of Altholw, then passing south of Ringwellerhot and north of posnt 382, rejoining the frontier of France at the ang le which 16 makes bout 1 k12ometre south of Hornbach (see Map No. a scale 2/100,000 annexed to the present Treatyd

A Conmission composed of fire nombers, one appointed by France, one by Germany, and three by the Councli of the League of Natlone, which w121 seleot natlonale of other Powers, w121 be oonstituted within fifteen days from the ooming into force of the present Treaty, to trace on the spot the frontier 21ne desorlbed above.

In those parts of the preceding line which do not colneide with administratire boundaries, the Commission w112 endearour to 


\section{2}

keep to the line indicated, while taking lnto consiaeration, so far as is possible, 2ocal economic intereste and existine commal boundar1es.

The decisions of this Comission w112 be taken by a majority, and $w 111$ be bind $1 n_{E}$ on the partios concarned.

\section{ARTICLE 49.}

Germany renounces in favour of the Loague of hations, in the capacity of trustee, the govornant of the territory defined above.

At the end of fifteen yours from the coming into force of the present Treaty the Inhabitante of the ald territory shall be called upon to indicate the sovorelenty under which they desire to be placed.

\section{ART TCLE 50.}

The stipulations under which the cession of tho mines in the Saar Besin ahall be carried out, together with the measures intended to equaratee the rights and the well-being of the luhab1 tante and the government of the territory, as well as the conditions in accordance with which the plebisclte herelabefore provided for is to be made, are lald down in tho Annex heroto. Thie Annex shall be considered a an integral part of the prosent Treaty, and Germany deciares her adherence to 1 t.

ANNEX

In accordance with the provisions of Articles 45 to 50 of the prosent Treaty, the stipulatione under which the cesion by Gormany to France of the mines of the Saar Basin will be effected, as well as the measures intended to ensure respect for the rights 
and woll-being of the population and the government of the territory, and the conditione in which the lahabitants will be called upon to indicate the sovereignty under which they may wish to be placed, have been lald down as follows:

CHAPTER I.

CESSION AND EXPLOITATION UF RININO PROFEKTY.

$$
1 .
$$

From the date of the coming into force of the present Treaty, all the deposits of coal situated within the saar bagin as defined In Article 48 of the sald Treaty, becone the complete and absolute property of the French State.

The Fronch State will have the rignt of working or not workIng the sald alnes, or of transferriug to a taird party the right of working them, without neving to obtain any previous authorieation or to fulfil any formalities.

The French State may always require that the corman mining 1aws and regulations referred to below shall be applied in order to ensure the determination of 1 ts rights.

$$
\text { 2. }
$$

The right of ownership of the French state w11l apply not only to the deposits which are free and for which concessione have not yet been granted, but also to the deposite for which concesslons have already been granted, whoever may be the present proprietors, irrospective of whether they belong to the prussian state, to the Bavarian state, to other states or bodies, to compantes or to 1ndividuals, whether they have been worked or not, 
or whether a right of exploitetion distinot from the right of the owners of the surface of the soll has or has not been recognized. As far as concerne the mines which are being worked, the tranefor of the ownershtp to the French stato w11l apply to all the accessories and eubsidiaries of the sald mines, in particular to their plant and equipment both on and below the surface, to their extracting machinery, their plants for transforming coal Into electric power, ooke and by-products, their workshops, means of oommunication, electric 21nes, plant for catchino and distributing water, land, butldings suoh as offlces, managers', employees' and workmen's dwellings, schools, hospltals and dispon-aries, their stooks and supplies of every description, their arohlves and plans, and in generel everything which those who own or explo1t the mines possess or enjoy for the purpose of explolting the mines and their accegsorites axd subsidiaries.

The transfer w111 apply also to the debts ow 1no for producte delivered before the entry into possession by the French state, and after the signeture of the present Treaty, and to deposits of money made by customers, whose rights will be guaranteed by the Fronch state.

\section{4.}

The Frenoh state $\mathbf{1 1 1}$ aoquire the property free and clear of all debts and charges. Nevertholess, the rights aoquired, or In course of beints aquilred, by the employees of the mines and their accessories and subsidiaries at the date of the coming into foroe of the present Treaty, in connection with pensions for old 
age or disab1l1ty, w11l not be affected. In return, Germany must pay over to the French state sun representing the actuarial amounts to which the sald omployeod are entitled.

\section{5.}

The value of the property thus ceded to the French state w111 be determined by the Reparation Commiseion referred to in Art101e 233 of Part VIII (Reparation) of the present Treaty, Th1s value shall be credited to Germany in part paymont of the amount due for reparation.

It w112 be for Germany to Indemnify the proprietors or parties concerried, whoever they may be.

$$
6 .
$$

No tariff ohall be established on the cerman rallways and canais whioh may direotiy or indirectiy diecrimine to to the projudice of the trensport of the personnel or products of the mines and their accessories or subsidiaries, or of the material necesaary to their oxplo1tation. Such transport shell onjoy all the rights and privileges whioh any international rallway conrentions may guarantee to similar products of French origin. 7.

Tho equipmont and personnel necessary to ensure the despatoh and transport of the products of the mines and the $1 r$ accessories and subsidiaries, as well as the carriage of workmen and employeea, 121 be provided by the local rallway administration of the Basin. 
8.

No obstaclo shall be placed in the way of such improvepents of rellways or waterways as the French state may judge necessary to assure tho despatoh and the trensport of the produots of the mines, and their accessories and subsidiaries, such as double trackage, enlargement of tations, and construction of yards and eppurtenanoes. The distribution of expenses w111, in the event of disagreent, be subaltted to arbitration,

The French state may aloo entablish any now means of communication, such as roads, elootrio lines and tolephono connections which it may consider necessary for the exploitation of the mines.

It may exploit eroely and without any restriotions the weans of oommuntoation of which it may become the owner, parthoularly those connectine the mines and their accessorles and subsidiaries with the means of comanication altuated in Frenoh territory.

$$
9 .
$$

The French gtate hall always be ontitled to dewand the application of the German mining lams and regulations in force on November 11, 2918, excepting provisions adopted exclualvely In view of the etate of war, ith a view to the acquisition of such land it may judge neossary for the exploitation of the mines and their scoeseories and subaldiaries.

The payment for damage caused to immovable property by the working of the sald aines and their accessories and subsidiaries 


\section{8}

shall be made in accordance with the German minthg laws and regulations above referred to.

10.

Every person whom the French State may substitute for 16self as regerds the whole or part of 1 ts rights to the exploitation of the mines and their accessories and aubsidiaries shall enjoy the benefit of the privileges provided in this annex. 11.

The mines and other Immovable property wich becone the property of the Frenoh State may never be made the subject of measures of forselture, forcod sale, expropriation or regulsition, nor of any other measure affecting the right of property.

The personnel and the plant connected with the exploitation of these mines or their accessories and subsidiaries, as wel1 as the product extracted from the mines or manufactured in their accessories and subsidiarles, may not at any time be made the subject of any. measures of requisition.

The exploltation of the alnes and their accessortes and subsidiaries, which become the property of the French State, w111 continue, subject to the provisions of paragraph 23 below, to be abject to the reglme establighed by tho terman laws and rogulatione in torce on November 11, 1918, excepting provisions adopted exclusively in riaw of the atate of war.

The rights of the workmen shall similarly be malntainod, subject to the provisions of the sald paragraph 23 , as estab11 shed on November 11, 1918, by the German laws and regulations 
above reforred to.

No Impediment shall be placed in the way of the introduction or omployment in the mines and their accessories and subsidiaries of workmen Irom without the Basin.

The omployees and workmen of French nationallty shall have the right to belong to French labour untons.

\section{3.}

The amount contributed by the mines and their accessories and subeldiaries, elther to the local budget of the territory of the saar Basin or to the communal funds, shall be sixed with due regard to the ratio of the value of the mines to the total taxable wealth of the Basin.

$$
14 .
$$

The French ste te shall almays have the right of establishIng and maintaining, as inoidental to the mines, primary or technioal schools for 1ts employees and their children, and of causIng instruction therein to be given in the French lansuage, in accordance with such currioulum and by such teachers as it may solect.

It shall also have the right to ostablish and maintain hosp1tals, dispensaries, workmen's houses and gardens and other charitable and social inatitutions.

$$
15 .
$$

The French State ahall enjoy complete liberty with respect to the distribution, dispateh and salo prices of the products of the mines and their acceseories and subsidiaries. 
Nererthe1eas, whatever may be the total product of the mines, the Frenoh Government undertakes that the requirements of $100 \mathrm{~d}$ conoumption for Industrial and domestic purposes oball always be satisiled in the proportion existinis in 1913 botween the amount consumed locally and the total output of the Saar basin.

CHAPTER II.

GOVERNIENT OF THE TERRITORY OF THE BAAR BASIN.

16.

The Government of the territory of the Saar Basin shall be entrusted to a Comalsaion representins the League of Nations. This Comalseion shall sit in the territory of tho saar basin.

$$
17 .
$$

The Governing Commiasion provided for by paragraph 16 hall consist of sive membere chosen by the Council of the League of Nations, and will inolude one citizen of France, one native inhabitant of the Saar Basin, not a cltizen of France, and three members belonging to three countrioe other than France or fermany *

The uember of the forerning Comiasion shall be appointed for one year and may be remappolnted. They can be removed by the Counoll of the Loague of Nat1ons, which w1ll provide for their replacement.

The members of the Governing Comatsston w111 be entitled to a salary whloh $\mathbf{W 1 1}$ be l1xed by the Councll of the League of Natione, and charged on the local revenues. 
28.

The Chairman of the Governing Commission shall be appolated for one year from among the members of the commission by the Council of the League of Nations and may be re-eppointed.

The Cha1rman w111 act as the executive of the commssion. 19.

Within the torritory of the Saar Basin the Governine Commiagion shall have all the powers of government hitherto belonsIng to the German Empire, Frussia, or Bararia, includins the appointment and dismissal of officials, and the creation of such administrative and representative bodies as it way deen nocessary.

It shall have full powers to administer and operate the railways, canalo and the different public services.

Its deo1stone shall be taken by a majority. 20.

Germany w11l place at the disposal of the bevernine Commiselon all official doouments and archives under the control of Germany, of any German state, or of any local authority, which relate to the territory of the saar besin or to the rights of the Inhabitants thereot.

$$
\text { 21. }
$$

It w111 be the luty of the Governing Commission to ensure, by such means and under such conditions as it may deem suitable, the protection abroad of the interests of the intrabitants of the territory of the Sear Basin. 


\section{8,}

The Governing Cosmisolon shall have the full right of user of all property, other than mines, belonging elther in public or In private domain, to the Government of the German bupire, or the Government of any Germen state in the territory of the sear Bas 1n,

AB regards the rallway an equitable apportionment of rollIng stook shall be made by alxed Commiasion on which the corernment of the territory of the Saar Basin and the German railways w111 be represented.

Persons, goods, veseels, carrlages, wagons and malls comIng trom or golng to the saar Basin shall onjoy all the righte and privileges relating to transit and traneport which are speciIled In the provisions of Part XII (Porte, Waterways and hallways) of the present Treaty.

\section{3.}

The lawe and regulatlons in force on November 21,1918 , in the territory of the Saar Basin (except those axacted in consequence of the state of war) shall continue to apply.

If. for general reasons or to brins these laws and regulations into aocord with the provisions of the present Treaty, it 18 necessary to introduce modifications, these shall be decided on, and put into effect by the Governing Comaission, after consultation with the elected representatives of the Inhabitants in such a manner as the Commission may determine, No modifloation may be made in the legal rogime for the ex- 


\section{2}

ploitation of the mines, provided for in paragraph 12, without the French state being previously oonsulted, unless such modification results from a general regulation respectiag labour adopted by the League of Nations.

In fixing the conditions and hours of labour for wen, women and chlldren, the Governing Comission is to take into consideration the whes expressed by the looal labour ortanizations, as woll as the principles adopted by the Loasue of Nations.

$$
\text { 24. }
$$

subject to the provisions of paragrajh 4 , no rights of the Inhabitants of the sear Basin acquirod or in process of acquisition at the date of the coming into force of this rreaty, in respoct of any insurance system of cermany or in rosject of any pension of any kind, are affected by any of the provialone of the prosent Treaty.

Germany and the Government of the territory of the Saar Basin w11 preserve and contimue all of the aforesald ribhts.

$$
25 .
$$

The civil and orimine l courts exieting in the territory of the saar Basin shall oont1 nue.

A o1vil and oriminal court w112 be establishod by the GovernIng Comission to hoar appeals from the decislons of the sald courts and to declde mattere for which these courts are not competent.

The Governing compission w11l be responsible for settling the organisation and jurisdiotion of the said court. 
Justice w111 be rendered in the nave of the forerning Commises 10n.

$$
26 .
$$

The Governing Commiasion w111 alone have the power of levyIng taxes and dues in the territory of Sear Basin.

These taxes and dues $\mathbf{w 1 2}$ be exolusively epplied to the noeds of the territory.

The I1scal system existing on November 11, 1918, will be maintained as far as poselble, and no new tax except oustoma dut1os way be imposed without prevlousiy consulting the elected representatives of the inbabitants.

$$
\text { 27. }
$$

The present etipulations w112 not affect the existing national1ty of the inhabitants of the territory of the saar bealn.

No hindrance shall be placed in the way of those who wsh to acquire a difforent natiomality, but in such case the acquisition of the new nationality 121 involve the loss of any other.

$$
28 .
$$

Under the control of the Covernias Comalssion the Inhab1-

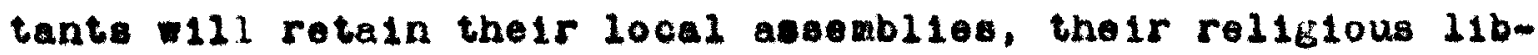
erties, their sohools and their language.

The right of voting will not be exerciged for any assembiles other than the local assembiles, and w11l belong to every inhab1tant over the age of twenty yoars, without diatinetion of sox. 29. Any of the Inhabitants of the Sear Basin who may desire to 
leave the territory $\mathbf{m l l l}$ have full liberty to retain in 14 their immorable property or to sell it at fair prices, and to remove the 1r movable property sree of any chargea.

30.

There w11l be no m111tary serv10e, whether compulaory or voluntary, in the territory of the Saar Basin, and the construetion of fortifloations therein is forbidden.

Only a local gendarmerie for the malntenance of order may be ertablished.

It w11l be the duty of the Governing Commission to provide in all cases for the protection of persons and property in the Saar Basin.

31.

The territory of the saar Basin as defined by artiele 48 of the present Treaty shall be subjected to the fronch customs regino. The recelpte from the customs duties on goods intended for local oonsumption shall be lncluded in the budget of the sald territory after deduction of all coste of collection. No export tax shall be imposed upon metallurgical products or coal exported from the sald territory to Germany, nor upon German exports for the use of the industries of the territory of the Saar Basin.

Natural or manufactured products originatins in the Besin In transit over German territory and, similarly, German producte In transit over the territory of the basin small be froe of 211 customs duties. 


\section{4}

Producte which both origlnate in and pass from the Basin Into cermany shall be tree of Import duties for a perlod of sive years from the date of the coming into force of the present Troaty, and during the same period articles imported from dermany into the territory of the Basin for $10 \mathrm{cel}$ consumption shall likewise be eree of import duties.

During these live years the Fronoh Government reserves to 1tsolf the right of liating to the annual average of the quant1ties Imported Into Alsace-Lorraine and France in the years 1911 to 1913 the quantities which way be sent into france of all articles coming from the Basin which lnclude raw materials and semi-manufactured goods laported duty free from Sermany. Such average shall be determined efter reference to all avallable official Information and statistics.

$$
32 .
$$

No probibition or rosiriotion shall be imposed upon the ciroulation of Fronoh woney in the territory of the Saar Besin.

The Fronch state shall have the right to use Fronch money In all purchases, payments and contracts conuected with the explo1tation of the mines or their accessories and subsidierios. 33.

The Governing Commission shall have power to decide all questions arising from the interpretation of the preceding proV1eions.

France and Germany agres that any dispute lnvolving a differenoe of oplnion as to the interpretation of the said provisions 
shall in the sane way be submitted to the Gororning Commission, and the decision of a majority of the commission shall be binding on botb countries.

ChAPTER III.

FLESIBOITA.

34.

At the termination of a period of iffteen years from the coming into force of the present Treaty, the population of the territory of the Saar Bastn w111 be callod upon to indicato their desires in the sollowing mariner:

A roto will take place by commue or districts, on the three following alternativas: (A) intenance of the regime ostablishod by the prosent Treaty and by this annex; (b) union 1th France; (c) union with Gerwany.

A12 persons without dietinction of sex, more than twenty yeare old at the date of the voting, resident in the territory at the date of the signature of the present Treaty, w1ll bave the right to vote.

The other conditions, methods and the date of the roting shall be Ilxad by the Counc1l of the League of Nations in such a way as to secure the freodom, secrecy and trustworthiness of the voting.

$$
\text { 35. }
$$

The League of Nations shall decide on the soverelgnty under whioh the territory 18 to be placed, taking into account the -1ehes of the inhabitants as expressed by the roting: 
(a) If, for the whole or part of the territory, the League of Nations decides in farour of the maintenance of the regime established by the prosent Treaty and this annex, Cormany hereby agrees to make such renunciation of her soverelgnty in favour of the League of Netions as the latter shall deem necossary. It w111 be the duty of the League of Vations to take appropriate stepe to adapt the regine definitively adoptod to the permanent welfare of the territory and the general interest;

(b) If, for the whole or part of the territory, the Laagua of Nations desides in favour of union with France, Cermany hereby agrees to oede to France in accordance with the decision of the League of Nations all rights and title over the territory spocifled by the Laague;

(a) If, for the whole or part of the territory, the League of Nations decides in favour of union with Germany, it will be the duty of the League of Nations to cause the German Government to be re-astablished in the government of the territory specifled by the Lague.

36.

If the League of Nations docides in favour of the union of the whole or part of the territory of the Saar basin with Germany. France's rights of ownership in the mines situated in suoh part of the territory w121 be reptrohased by Germany in their entiraty at a price payable in gold. The price to be paid will be elxed by three experta, one nominated by Germeny, one by France, and nne, who abell be nelther a Fronohman nor a German, 
by the Council of the Laague of lations; the docialon of the experts w112 bo given by a majority.

The obligation of Germany to make such payment shall bo taken into account by tho Reparation Commisiton, and tor the pirpose of this payzent cerasny ay create a prior charge upon her assets or revenues ugon such delalled teras as ahall be agreed to by the Reperation Comiasion.

I1, nevertbeless, Gerwany after a period of one year fron the date on which the paysent becores due shall not hare effect-d the sald payment, the Roparation Comission shald do so in acoordanoe with sucin Instruotions as bay be givon by tho Loague of Nationo, and, 18 necesaary, by 11quidatins that part of the mines which is in queation.

$$
37 .
$$

If, In consequenoe of the repurohase provided for in paraGraph 36, the ownerablp of the wines or any part of them 1s transFarred to Germany, the Frenoh state and Fronoh nationala shall have the right to purohase suoh amount of coal of the Saar Basin as their induetrial and dowestic noeds are found at that time to require. An equitable arrangement regarding amounts of ooal, duration of contract, and prices 111 be fixed $2 \mathrm{n}$ due tiple by tho Councti of the League of Nations.

$$
50 .
$$

It 1s undarstood that France and cermany may, by soolal agreemente concluded before the time fixed for the payment of the price for the repurchase of the mines, modify ihe provisions of paragraphe 36 and 37 . 


\section{8}

39.

The Counc1l of the League of Nations shall make ouch prom vislons as may be neoessary for the establighment of the regime whioh is to take effect after the decislone of the League of Natione mentioned in paragreph 35 have becone operative, including an equitable epportionment of any obligations of the covernment of the territory of the Sest Bas in erisiag from 20and raised by the commision or erom other causes.

From the coming into force of the new regiwe, the powers of the Governing Comminaion w112 tarminate, except in the case provided for in paragraph 35 (a).

40.

In all matters dealt with in tho present ancox, tho decisions of the Council of the League of Nations w11l be taken by a major1ty, 
BIBLIOOEAPHY

$-$ 


\section{SELECT BIBLIOORAPEY}

SOURCE MATERIAL

Baker, R. S. and Dodd, W. E. .Publue Papere of Woodron When. 6 rols. Now York and London. Karper and Brothers, 2925.

Baker, R. S................ Woodrow W11soni Life and Lot ters. Page and Company, 2927.

League of Nattons: Offlelal Journel. "Saar Torritory," Includes all Journals published 1980 to 2935 inodusive. Cenera.

League of Natlong. Tron Tear te Year. League of Nations (Insormation Seotion) 1821 to 1935 inclusive. Genera.

League of Nat Ions...........Coung1h Doouments. Hunutes of the Connell. Loagua or Nations. Conota. I980 to 1935 inolualve.

Lague of Nations............ Economio Combittee. Pan Hateriale Problen. Vol. 2, Deneva, 1921.

Heyers, Denys P........... Mine Years of the Lague of Lationg19P0-1928. (Ninth Yoarbook) Vol. XII, No. I, Boston, Wor2d Peace Founda t10n, 2929.

Seymour, Charles............ The Intrate Papers of colonel Houne. ToIs. Hew York, Houghton, IITxiln and Company, 1926-28.

Ireaty of versellues.

\section{PERSONAL NARRATIVES}

Arthus, sir George........... Hamolre of Baymond Potngere. Garden CIty. N. W. Doubleday, Page and Company. 2989.

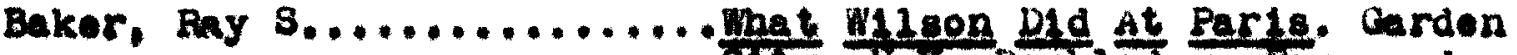
CIty, N,Y, Doubleday, Fage and Company. 2980. 


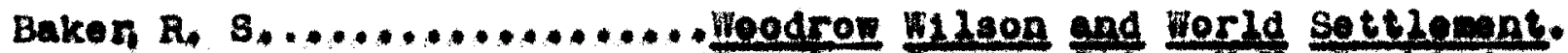
3 vols. Garden CIty, N. Y. Doubleday, Page and Company, 1982.

Drummonds, Er10............Ten Ieare of World Comoperation. League of Nitions, Boston. World Peace Foundation, 1930.

Goorge, David Lloyd.........The Truth Ahout Rearatione and Wer Debts. Wor York, Doubloday, Pago, and Company, 1838.

Haokins, Chas.H. and Lord, R.H..Some Probleme of the Pence GonCerence. Cambridge, Harvard Univerelty Fross, 1980 .

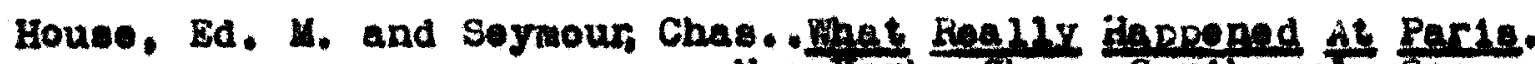
New York, Chas. Sortbnor's Bons, 1982.

Lane 1ng, Robert............. The B1s rour and Othere of the Peace conference. Boston and Non York, Houghton Iifelin Company, 1921.

Lansing, Robort............. The Besce Nesowatlons, A Personsl Nerratire. Boston and Now York, Houghton UITIIIn Company, 1921.

Poinoare, Baymond........... The Henotre of Enyend Poincare. 2 vols. Not York, Doubioday, Doran and Company. 1928-1989.

Priou, Jean................ The Territery De La Seare. Par18. 1923.

Tardieu, Andre............. The Truth About the Treaty. IndianaFol1s, Ind. The Bobbs-iberri11 Company. 1921.

Temperley, Harold W. V........A Hiatory of tho Peece Concerenee. Now York, Oxford University Frene. London. H. Frowde Hodder and Stouchton, 2820-1984.

GENRRAL WORKS

Armetrong, Ham1גton F........ Europe Betieen Were. Wew York, Tho raomilian Compañ. 1934.

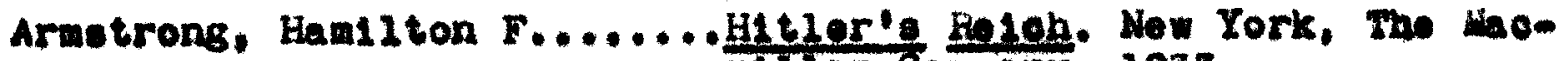
atIItan Company. 2933. 


\section{8}

Bake less, John.................The Beonomle Gauses of Modern Wer. Now York, Vhing Prose, TH2L.

Baruch, B. M.............. The Hakeng of the fieparation and zoononte sections of the treaty. Now York and London, harper and Brothers, 2980.

Bausman, F............... Lat Erange Explain. London. Coorgo Allen and Union. Ltd. 1928.

Bowman, Ibalah............ The Nen World; Problems 1n Pol1410al Choureohy. 4 od. Yonkers. World Book Coupany, 1928.

Bryoe, James............... Internathol Belationg, New York, Now York, The Kagalizen Company, 1922.

Bue 11, R. 2............... Contenporary Erench Rolltles. Now York, Apploton, 1980.

Bue11, Raymond L............Nex Gorergeents In gurope. Nen Iork Thos, Noleon and Sons, 1934.

Cert, Barry.................Aleace-Lorralne S1nce 1870. Now York, The Xaonilian Company. I9I9.

Cook, W. Honry and st10knoy, 8. P. Beading In European Internationel Eelations. Now York, 1931.

Crosby, $0.7 . \ldots . . . . . . .$. Intermatlonal Wer. Its Cauges and Its Cure. London, and Now York. VaceizIen Company, 2929.

Dona 1d, sir Robert........... Danzer Spet in Burope and Itg Goreximent of the League of Baclong, tondon, 1925.

Zoke1, Bdwin C.............. Goal, Iron and War. New York, Ho 2t, 1930.

Floringky, Mlohael........... The Saar Struggle. New York, The MacIIIIan Company. 1934.

Freowan, 3. A............... The Hletorloal Gography of Europe. 3 od. London, and Now York, Longmans, Green and Company, 1903.

Goorge, Devid Lloyd.......... In It Bese? London, 2923. 


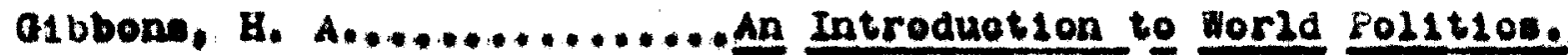
iov xork, ite Contury Company. 29ER.

Otbbone, H. A..............The Hen lep of Burope (2911-1924) How Tork. Ino Century Company. 2924.

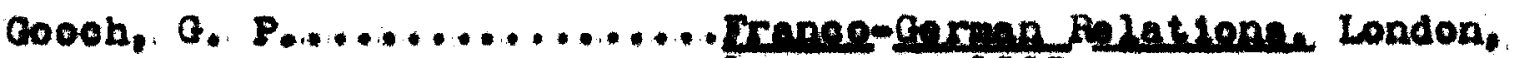
Longmans, 2983.

Gooch, O. P...............Htator of vodern Europe. Nen York, HoI6, 1983.

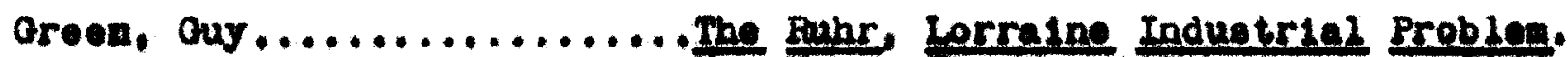
ITw Tork, The Lanilian Company. Ior.

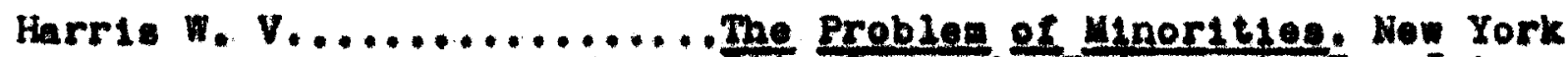
cIty Carnegie sidomment. For International Pasoe. 1986.

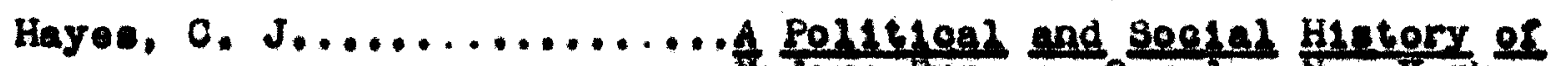
Eodorn surop. 2 vols. Non York. The VeoñLlan Company, 1924.

Hasen, C. D........................ Lorreine Under Germen Enle. How rork, Honry Holt and Company. 1917.

Hasen, Charles D........... Mrepe 81nes 2815, Non York, Hanry Holt and conpany, 1926.

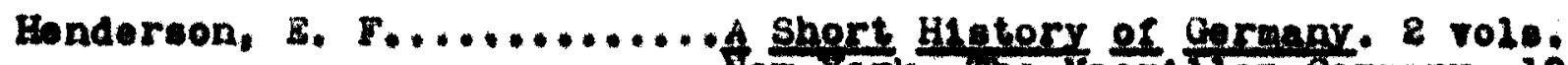
Non rork, ine riomidien Company, 1927.

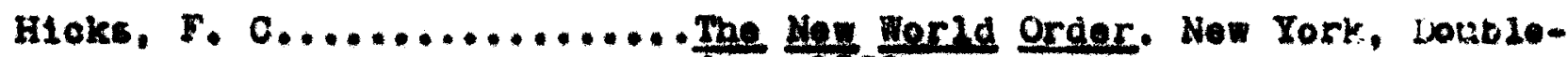
day, 1900.

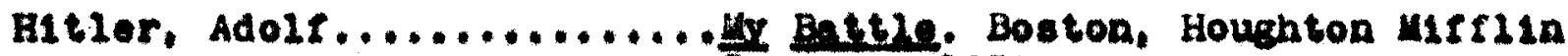
Company. 2933 .

Jackson, Henry E...........The Leapue of Mationg. Now York, PrenELe Hall, Ino., 1919.

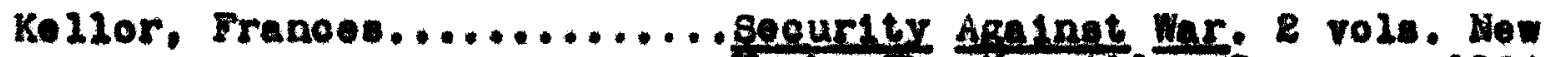
Tork, The lacailian Company, 1824.

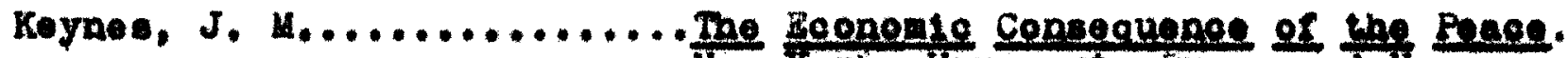
Wen York, Haroourt, Braoe and Howe, 1920.

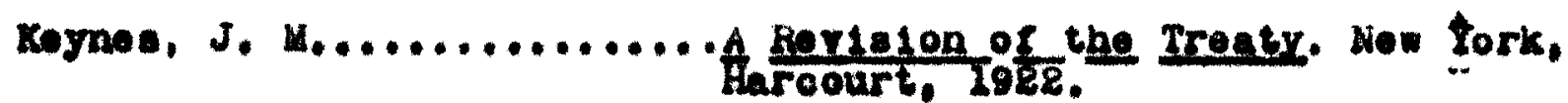




\section{3}

Kahzwann, Rlohard Von........ Thoughts on Germany. Mow York, Tho Isemilian Company, 1982.

Ladas, s. P...............Tha Internationel proteetien of Indut trat propery. Cambride, harrara Unitreralty ETe日8, 1930.

Langeam, . C............. The World Singe 1924, Now York, The tromilian company. 1933.

Langer, w. L............... parepen AlHenges and Alknmente. How Tork, Knop?, 1931.

Latané, J. H................. Higtory of Amarloan Forelon Polior. Dit rork, Doubloday, 20ET.

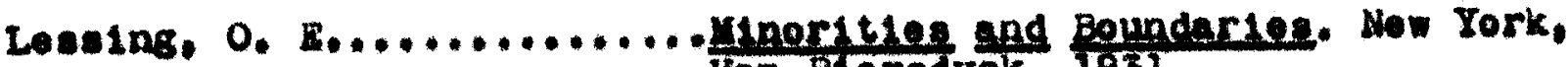
Van kiemsdyok, 1931.

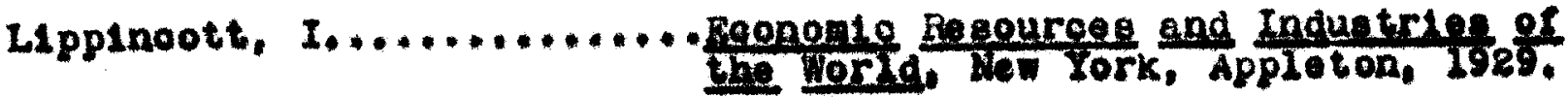

Lipprann, $w$. and soroggs, $w$. O.. The United statee 1n torld Affeire. Now York, har per. Annual Slnce 1931.

Hargal1th, A. K.............. The Internghlonel Hendates. Baltimore Jown topkine Prose, 1930.

Wathows, J. H...............Agerlean Foreleg Bedetlong. Wow York, contury. 1928.

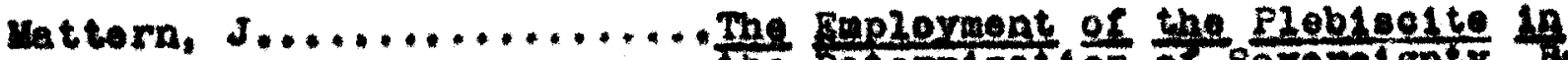
Whe Dinernation ot sorerolmh. BalBinore, Jokn hopkino Pross, 1920. u122er, D. H............... The Feneg Pret of Parle. Nen York

Moulton, H. G. and MoGuire, C, B..Germany's Gapalty to per, New Tork, Publisher Unknown, Ioxs.

Moulton, H. G. and Bess, J. F..Americe and the Balanee Shaet of mirope. Ho York. ino Roland Prose Company, 1921.

Youlton, H. O. and Low1s, C. The Jrengh Dabt Rroblem, Now Xork, The Vaomlizan Company. 1925.

Howat, R. B............... The guropean states Sreten: A Study of Intromationat io lation. London, oxtord Univereity Prose, 1989. 
Mower, B. C.................Interngtlonel Government, Now York, Eath and Company, 1931.

Nonbegta, Marion I..........Aftereath: A Geographiont Study of the Lene Terme. London, W, and A.K. Johneton Lintied Ed Inburgh. General Agonts. Homklian and Company. 2920.

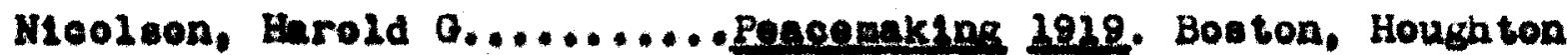
urting, 1933.

Noyes, P. B................. Hhlle Burene Deste for Pesce. New York, 1981.

Os8. F. A............... purepeen Goverpmente and Pollt10s. Mew Xork, The thomlizian Company. 2934.

Oldon, Rudo1f.................strestame. Non York, Dutton, 2930.

Osborne, s1dnoy.............. The Sanr 3uest10n. London, 2923.

Potter, P. B............... Introduotion to the Study of Interntiongl orsanization. Non York, contury company, Iozz.

Rawles, $x$. P............... The Hational1ty of Commerolal Gontrol of varlo Minerala. Now Iork, Amorioan Institute of IIning and Hotaldargical Ensineers, 2933.

Russed, Trank M............. The Interngt 1onal gorernaent of the Bar. Berkoloy, Cal. University of Callfornia Probs, 1926.

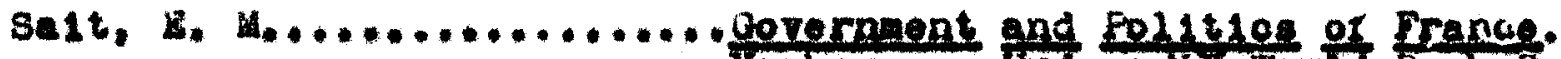
Yonkers on Eudeon, 1 . Wor Id Book Company, 2980.

Sayre, Tranees B............ Experigente iq International AdEndetration. Wow york, 1025:

Bohov112, F. A............. Pel1t1egh Hitory of Hodera Europe Now York, haroourt, 1921.

80ott, James Brown........... Qutbreak of the Zuropen Wer, 2 vols. Won York, Oxiord Uniters ity Prese, 1926.

Boott, Jame Brown.......... Pre 21minary Hletory of the Armietice. Won York, Oxírd Unt versity Prose. Bou. 
Sohuman, Froderiok L.......... International Pollt2es. Now York, MoGran-ALII Brook Company. Inc., 2933.

Sohuman, Froderick L......... Ner end Dlplomeox in the Fronoh Bepub 12. NoW York, WoGraw-kIL Brook Company, Inc., 1932.

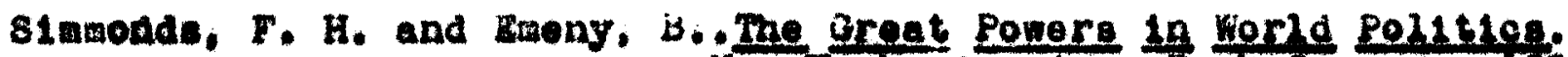
NOT Xork, Amor Loan Book Company. 1935.

slosson, P. W.............. mentieth Gentury gurope. Boston, Houghton uiti12n, 2927.

Sa1 th, Geo. 0.............. The Stretegy of Mrgeralg. New York, Apploton, 1929.

Soltau, R, H.................Erenoh 2021t1eal Thought in the 19th Contury. Now Haven, Yalo University Prese, 1931.

Soltau, R, B.................French Pertien and Pol14108. 18721930. New Tork, Oxford University Prose, 2930.

spahr, w. E............... Econonle Princlples and Probleme. Cornmall, H.Y. Cornwail Prose and CO. 1938 .

Stegenann, Hermann........... The strugele Lor the gh1ne. Now York Knopt, 2987.

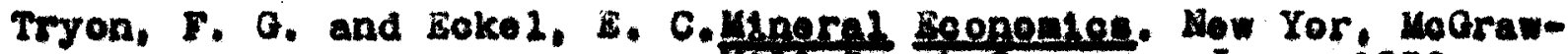
IIII Brook Company, Ino., 1932.

Van Loon, Honrtch............. Qnogrephy, Now York, Simon and Sohuster IO38.

Wallace, B. B. and Edministor, L. R. Interpatlogal Control of Ban theteriale. Washington, Brookinge inatitution, 2930.

Nanbaugh, Sarah..............Plrblectte slace the Forld Wer. WabhIngton, Carnegie Bndownent, 1933.

Wr1ght, Quincy.............. Mandates Under the League of Nationg. Chiodgo. I21. The Uniteraity of chloago Prosa. 2930.

Z1 memann, E. W............. Horld Fegurees and Induetries, Wew York, Earpor, 1933. 
v. S. COVERNAEMT DOCUMCANS.

Brooks, A. H. and La Crolx, M. F.. The Iron and Aspootated Induatrice of Lerralne, The sar Dratriet, Lixee"

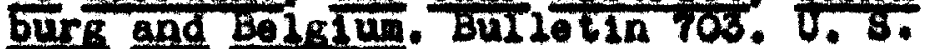
Gologloal survey, Waohington, D. C. U. 8. Covernment Printing office, 2980.

Butts, Thos............... The Erengh Irop and Steed Induetry and Irade. Irado Intorwation builetin Wo. 800, Hashington, D. C. U. S. Dorornment Printing of $100,2932$.

Hazen Char 10: D.............The Gerernment of Germeny. Washington D. C. U. S. Covernment Printing offlee 1927.

Lane1ng, Robert............A tar of Belf-Defenge. Mashlngton, D.C. 6. 8. Covernent Printins ors10e, 1917 .

LLohtenbergor, Henr1........ The Buhr Cons11at. Nashington, D. C. Carnogio Endownent for International Peace. No. 29, 1923.

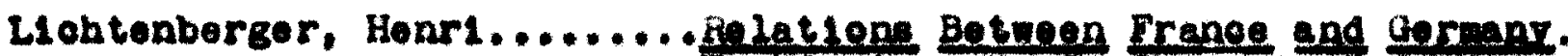
Warington, D. C. Carnogie hadownont for International Peaco. No. 28, 1923.

M1lier, H. D................. The Pegee Peat of Parle. New York.

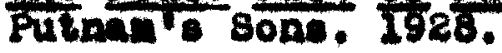

Roessler, Max..............The Iron gre Essources of Mreph. U.8. coological surtey, Buizetin 706, washington D. C.. D. S. Covernent Printing orf 10e, 1981.

\section{PERIODICALS}

Around the world..........."Saar" The Amerlean Qbeerrer. IV (Jan. 21, 2935) p. 3 .

Around the world.........."Germanj" the anerleen gonerwer. IV (Jan. 28, 2935) P. 3 .

Baldwin, E. L............... "A Littlo-known Busfor 8tate." Qntlook. New York CXXXIII, (Apr12 12, 2925) Pp. $650 \mathrm{~m} 52$.

Brigham, A, P................"Prinolples in the Determination of Boundaries." Goographleal Revien, VII 1935. PP, $802101 \%$

Cartel21ere, Walter.........." "Germany and You." Ber21n. (2834), No. 4, P. 12. 
Dean, 3dgar F.............. The Saer and Human Nature." Herpera Lagesine. GLXX (Jan. 2935), p. 835 .

De21, Robsrt................"A Visit to the Sar." Gentemperary Earles. CXXIII (throh 2923) PD. 36845

De11, Robert.............."Correapondenoe, The Loegue o Nat1on: and the saer." IhI Stateenan. XVI, (Lay 29, 1923), P. I68.

Editorial Correapondence....." Poace in the Sear." The Ghrigtien Century. LII, No. 2 (Jan. E, 2086) B. 8 .

Fodor, H. W............." "Saar Ploblsc1te." Anerloan Morqury. XXXIII, (Dec, 2034), PP. I8-2E.

Forelgn Comment............"Plob1solte Day in the Saer Territory." The Literary Diseat. CXIX (Jan. 20, IDss). p. 13.

Forelgn Comment............ "Loague Awarde saar to Germany." The Llerary Dheet. CXIX (Jan. 26, 1935). p. 35.

Fay, Sidney................. "The Fate of the saer," Gurrent History YLI (Jen, 1935), p. 405.

Hesk1ns, C. H............. "The Bear Territory as It Is Today." Forelen Afralre. Now Xork. 2 Ho. 2, (Dec. 15, 2922), Pp. 46-58.

Headley, Horlay............." Sear Valloy" The Gontenuerary Eerilez CXXY (Jan, Loe9), P. 475.

Iscerman, $F$. H............ "Dere the Sear Vote For Freedon," Chrlettan Century. LI (Nor. 24, 2935) PP. $2453-55$.

Johneon, Albin.............. "guandary in the Saar." New Outlook (Nor. 2934) CLXIV p. 22.

Kauteky, Kar1................ "Gormany S1nce tho Har." Forelga Alfain N. Y. I. No. 2, (Dec. 16, 1922) PP. 99-129.

Le1th, C. K................"The World Iron and steel Industry in 16. Bearing on the Frenoh Occupation of the Ruhr." Eorelag siftairs. N.T. I. No. 4, (Jun 25, 1923) PP. 236-51

Lovalnv111e. Jacques.........."Tho French Iron Industry After the

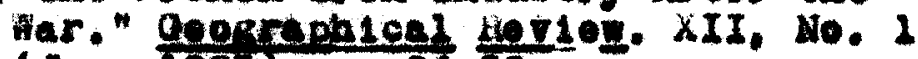
(Jan. 1985), P. 86-98. 
Pinon, R..................."Torritorial Clains of France," Atlantic Monthly CXXIII (Har, 2929) P. $396-404$.

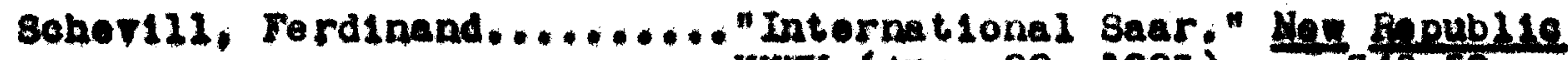
XXXV (Aug, 22, 2923) pp. 348-50.

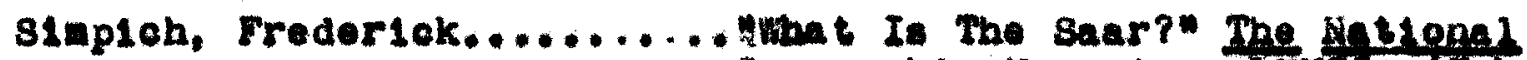
Gographto Hagatage IEvit, (Fob. 1935). P. 847.

staley 8..................."Private Investments and Internation. al Polltios in the sear." Paltiton. Poenear XLI (0ot. 2933): pp. Brifor.

Thompson, D................. "Knox of the Sear." Saturdar irentag Boet CoVII (Nov. 10, I934) Pp. 16-16.

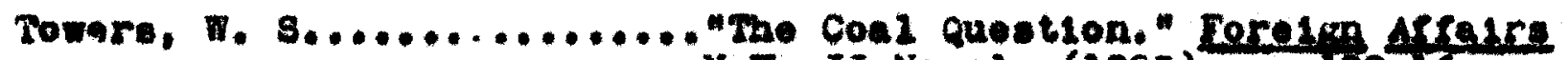
N.T. II No. 2, (1983) PP. 100-16.

villard, Harold G............"The Loague of Matlons and the smar." South Atlantio puarterly XXVIII, No. 5. Tutis 2089), p. 253 .

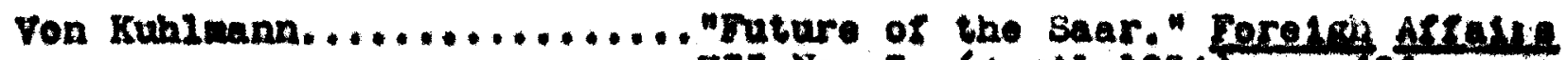
XII No. 3. (Apr11 2934), P. 626.

W1211ame, W................"Germany, The League and the sear" Sordbnere. IXXI No. 4. (Apr. 1022) p. 461-64.

WIokemann, Bl12..............."In the Eaar thla sumer." The Gantemecisiy Berlar. CXLVI (8ept. 2534$)$ PP. 317-18.

NBWEPAPERS

Chlosge Tribune..............."gaar supplemente." Nos. 1 \& 2, Chicago 1934. June 13.

The Herald Poet..............Louisville, Kontuoky, 2835, Harch 2.

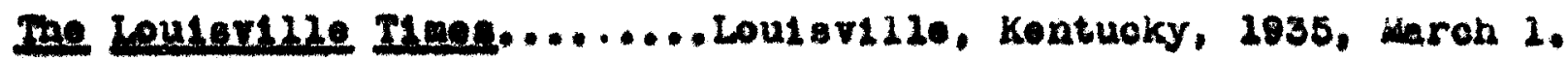
Liex Xork IInes............... Now York, 1934, Aug. 27. Ien Tork Jimes.................Now York, 2035, Apr11 20. Yolkerband..................ño. LXXXVII, Ber21n, Cermany, 2934 , Bob. \&. 